A Food and Agriculture Organization of the United Nations

\title{
Improving our knowledge on small-scale fisheries: data needs and methodologies
}

Workshop proceedings

27-29 June 2017

FAO, Rome, Italy

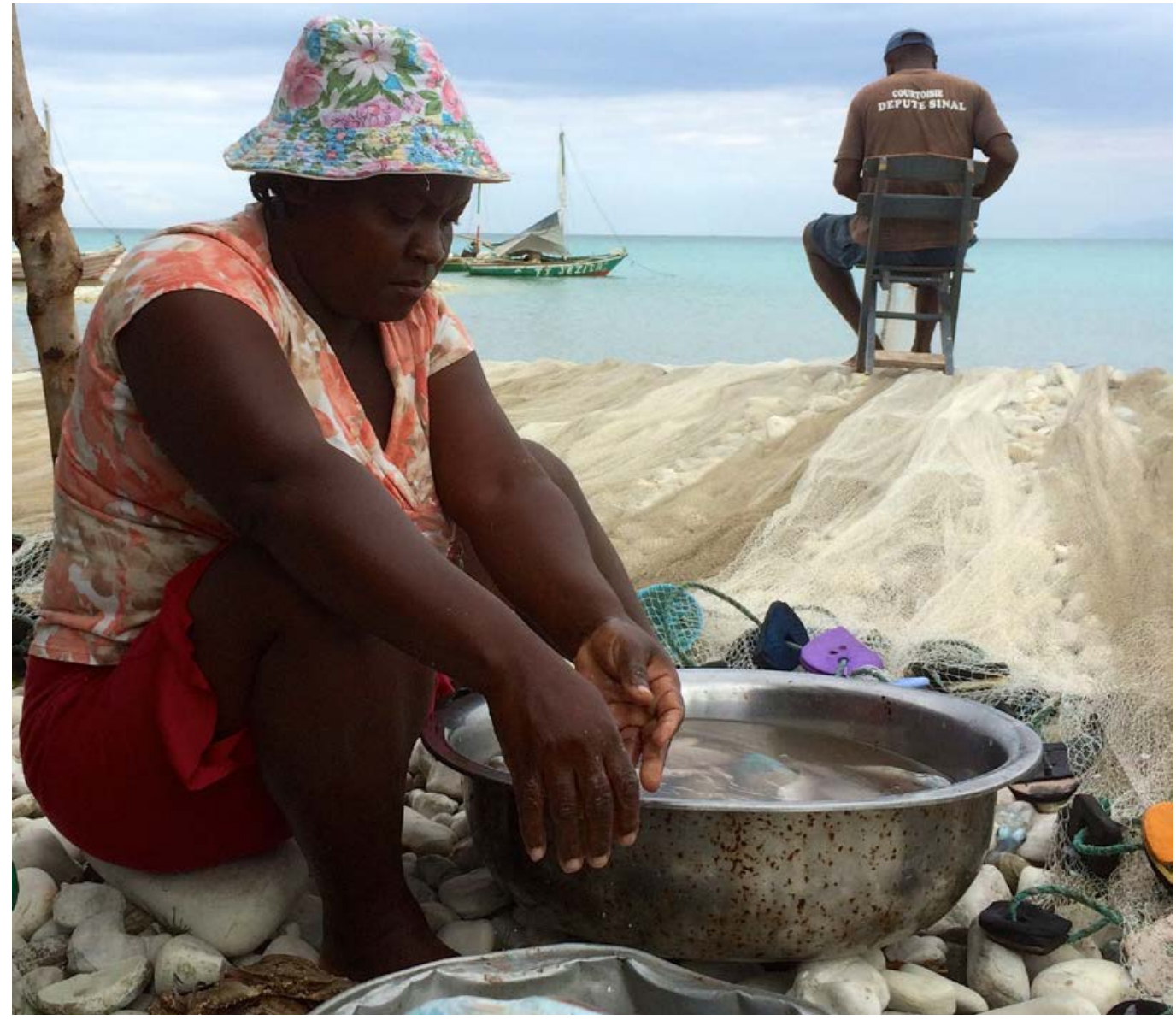


Photo credit: FAO/Lena Westlund 


\section{Improving our knowledge on small-scale fisheries: data needs and methodologies}

\section{Workshop proceedings}

27-29 June 2017

FAO, Rome, Italy

Xavier Basurto

Associate Professor, Nicholas School of the Environment

Duke University, Durham, USA

Nicole Franz

Fishery Planning Analyst

FAO, Rome, Italy

\section{David Mills}

Research Lead, Timor-Leste

WorldFish Center, Dili, Timor-Leste

John Virdin

Director, Ocean and Coastal Policy, Nicholas Institute

Duke University, Durham, USA

Lena Westlund

FAO Consultant

Stockholm, Sweden 


\begin{abstract}
The designations employed and the presentation of material in this information product do not imply the expression of any opinion whatsoever on the part of the Food and Agriculture Organization of the United Nations (FAO) concerning the legal or development status of any country, territory, city or area or of its authorities, or concerning the delimitation of its frontiers or boundaries. The mention of specific companies or products of manufacturers, whether or not these have been patented, does not imply that these have been endorsed or recommended by FAO in preference to others of a similar nature that are not mentioned.
\end{abstract}

The views expressed in this information product are those of the author(s) and do not necessarily reflect the views or policies of FAO.

ISBN 978-92-5-130018-3

(C) FAO, 2017

FAO encourages the use, reproduction and dissemination of material in this information product. Except where otherwise indicated, material may be copied, downloaded and printed for private study, research and teaching purposes, or for use in non-commercial products or services, provided that appropriate acknowledgement of FAO as the source and copyright holder is given and that FAO's endorsement of users' views, products or services is not implied in any way.

All requests for translation and adaptation rights, and for resale and other commercial use rights should be made via www.fao.org/contact-us/licence-request or addressed to copyright@fao.org.

FAO information products are available on the FAO website (www.fao.org/publications) and can be purchased through publications-sales@fao.org. 


\section{Preparation of this document}

This document provides a summary of the presentations, discussions, conclusions and recommendations of the "Workshop on improving our knowledge on small-scale fisheries: data needs and methodologies", held at FAO headquarters in Rome, Italy from 27 to 29 June 2017. The report was prepared by the organizers of the workshop from the Fisheries and Aquaculture Department of FAO, WorldFish Center, and Duke University. The background paper in Annex 5, prepared by Xavier Basurto and John Virdin of Duke University, is a slightly updated version of the paper that was submitted to participants prior to the workshop. This background paper is reproduced as submitted, including the annexes. 


\section{Abstract}

In 2012, the World Bank, FAO and WorldFish Center published a review of the economic importance of fisheries entitled Hidden Harvest: The Global Contribution of Capture Fisheries. While providing essential information and estimates that are still valid, the analyses would benefit from being refined and updated, and also by including additional dimensions of the contribution of small-scale fisheries to food security and nutrition, poverty reduction, and the three dimensions of sustainable development more broadly. The intention would be to draw the attention of policy- and decision-makers to the sector's importance and to promote the required engagement and support to realize the potential of sustainable small-scale fisheries. Such an analysis would also be an important contribution towards monitoring the implementation of the Voluntary Guidelines for Securing Sustainable Small-Scale Fisheries in the Context of Food Security and Poverty Eradication (SSF Guidelines), and of the progress towards the achievement of the Sustainable Development Goals (SDGs).

As a first step towards a new Hidden Harvest study, the "Workshop on improving our knowledge on small-scale fisheries: data needs and methodologies" was held at FAO in Rome, Italy on 27-29 June 2017. This expert workshop discussed:

- the scope and main contents of the new study, including type of data (indicators) to be collected and subsector coverage; and

- the methodologies for data collection and analyses, including key partners and information sources.

About 40 external experts, as well as FAO staff from the Fisheries and Aquaculture Department and other relevant FAO departments, participated in the workshop. The workshop agreed on the need for a comprehensive new study to illuminate the hidden contributions of small-scale fisheries to the three dimensions of sustainable development, as well as identifying the key threats to these contributions. The study would be a collaborative effort, and the next steps envisaged include the development of a study design based on the workshop outcomes, to be completed by the end of 2017; continuation of ongoing communications and partnership development; and launch of the research in early 2018, with a target for completion in the first half of 2019.

FAO. 2017. Workshop on improving our knowledge on small-scale fisheries: data needs and methodologies. Workshop proceedings, 27-29 June 2017, Rome, Italy. FAO Fisheries and Aquaculture Proceedings No. 55. Rome, Italy. 


\section{Contents}

Preparation of this document

Abstract

Acknowledgements

Abbreviations and acronyms

Executive summary

Background to the workshop 1

Introductory session 2

Opening Statement 2

Introduction to the SSF Guidelines 2

Reflection and recap on the 2012 Hidden Harvest process and outcomes: strengths, weaknesses and lessons learned 3

Presentation of background paper 5

What do we mean by small-scale fisheries? $\quad 6$

$\begin{array}{ll}\text { Comments and discussion } & 9\end{array}$

$\begin{array}{ll}\text { PLENARY PRESENTATIONS } & 10\end{array}$

$\begin{array}{ll}\text { Key areas for which data and information are needed } & 10\end{array}$

Updating the FAO assessment of the status of inland fisheries $\quad 10$

$\begin{array}{ll}\text { Assessing coastal fisheries } & 11\end{array}$

Frameworks for assessing local-level conservation and stewardship in small-scale fisheries $\quad 11$

Comments and discussion $\quad 12$

Data/information, sources and methodologies that can be useful for the new study

FAO global statistics, data frameworks and ongoing experience with data collection for improving data of small-scale fisheries

Revealing the socio-economic features of small-scale fisheries in southeast Asia

Data collection methods for small-scale fisheries $\quad 14$

Subsidies: small- versus large-scale fisheries subsidies $\quad 15$

$\begin{array}{ll}\text { Indigenous coastal communities } & 16\end{array}$

Constructing consumption aggregates for food security analysis using household income and expenditure surveys from the Pacific Island Countries and Territories

A bite into the nutritional value of fish 20

Small-scale fisheries in Morocco $\quad 22$ 
Session 1: What do we want to know about small-scale fisheries and why?

Session 2: Where or how can we find the data, and what methodologies should we use for data collection and analysis/ extrapolation?

Session 3: Suggested next steps and potential partnerships

SUMMARY OF WORKING GROUP OUTCOMES AND PLENARY DISCUSSIONS

CONCLUSIONS AND RECOMMENDATIONS 31

Conclusions 31

Recommendations 33

Annex 1 - List of participants 35

Annex 2 - Workshop agenda 38

$\begin{array}{ll}\text { Annex } 3 \text { - Opening statement } & 40\end{array}$

Annex 4 - Working group distribution 42

Annex 5 - Background paper 43

I. Introduction: What do we want to know about small-scale
fisheries and why?

II. Objective and methodology of this background paper 51

III. Results: Inventory of available data 53

IV. Results: Proposed available indicators and data collection methods $\quad 58$

V. Discussion: Proposed approach and case studies 66

References $\quad 69$

Appendix 1. Summary of measures estimated in Hidden Harvest 78

Appendix 2. Synthesis of measures submitted to TBTI's ISSF since 201079

Appendix 3. Full list of indicators searched in the scientific literature $\quad 81$

Appendix 4. Synthesis of measures recorded in scientific literature since 2011

\section{Tables}

Table 1. Template for compilation of information from case studies (2012 Hidden Harvest study)

Table 2. Proposed index for small-scale fisheries characterization 8

Table 3. SPC Coastal Fisheries goals, outcomes, policy relevance and indicators 19

Table 4. Consolidated list of potential indicators/variables to measure socio-economic contributions of small-scale fisheries 26

Table 5. Threats to socio-economic contributions of small-scale fisheries 30

\section{Figures}

Figure 1. Theoretical representation of distributions of catch and consumption data 


\section{Acknowledgements}

The "Workshop on improving our knowledge on small-scale fisheries: data needs and methodologies" greatly benefited from the dedicated contribution of a large number of individuals, including colleagues of the FAO Small-Scale Fisheries (SSF) Task Force from WorldFish and Duke University, namely Philippa Cohen and David Mills, and Xavier Basurto and John Virdin, respectively. All of them are gratefully acknowledged for their efforts during the preparation as well as throughout the workshop.

Sincere thanks are due to all workshop participants for their high-quality contributions and active role in workshop discussions. The organizers are particularly grateful to the presenters and to the facilitators and rapporteurs of the working groups.

Financial support for this workshop was provided by the Norwegian Ministry of Foreign Affairs through the Technical Assistance Project "Enhancing the contribution of small-scale fisheries to food security and sustainable livelihoods through better policies, strategies and initiatives", under the FAO Umbrella Programme for the Promotion and Application of the SSF Guidelines. The support is greatly appreciated. 



\section{Abbreviations and acronyms}

$\begin{array}{ll}\text { ACFR } & \text { Advisory Committee on Fisheries Research } \\ \text { ADG } & \text { Assistant Director-General } \\ \text { CFS } & \text { Committee on World Food Security } \\ \text { CIP } & \text { Coastal indigenous peoples } \\ \text { COFI } & \text { FAO Committee on Fisheries } \\ \text { CPUE } & \text { Catch per unit effort } \\ \text { CSO } & \text { Civil society organization } \\ \text { FAD } & \text { Fish aggregating device } \\ \text { FAO } & \text { Food and Agriculture Organization of the United Nations } \\ \text { FAOSTAT } & \text { Food and Agriculture Organization Statistics Division } \\ \text { FCPs } & \text { FAO Fisheries Country Profiles } \\ \text { FIRMS } & \text { Fisheries and Resources Monitoring System } \\ \text { GDP } & \text { Gross domestic product } \\ \text { GEF } & \text { Global Environment Facility } \\ \text { GRT } & \text { Gross registered tonnage } \\ \text { HIES } & \text { Household income and expenditure survey } \\ \text { IMAS } & \text { Institute for Marine and Antarctic Studies } \\ \text { INRH } & \text { Institut National de Recherche Halieutique } \\ \text { ISSF } & \text { Information System on Small-Scale Fisheries } \\ \text { IUU } & \text { Illegal, unreported and unregulated } \\ \text { MSC } & \text { Marine Stewardship Council } \\ \text { PICTs } & \text { Pacific Island Countries and Territories } \\ \text { SAUP } & \text { Sea Around Us Project } \\ \text { SDG } & \text { Sustainable Development Goal } \\ \text { SEAFDEC } & \text { Southeast Asian Fisheries Development Centre } \\ \text { SOFIA } & \text { The State of World Fisheries and Aquaculture } \\ \text { SOIFR } & \text { The State of Inland Fishery Resources } \\ \text { SPC } & \text { Pacific Community } \\ \text { SSF } & \text { Small-scale fisheries } \\ \text { TBTI } & \text { Too Big To Ignore } \\ \text { UNGA } & \text { United Nations General Assembly } \\ & \end{array}$




\section{Executive summary}

A "Workshop on improving our knowledge on small-scale fisheries: data needs and methodologies", was held at FAO headquarters in Rome, Italy, on 27-29 June 2017. The workshop was attended by approximately 40 external experts from government, research institutions, and intergovernmental and regional organizations, as well as FAO staff.

Small-scale fisheries play an important role in contributing to food security, nutrition, livelihoods and local and national economies. However, there is often limited data and information available (or not easily accessible) on their contributions, and hence small-scale fisheries tend to be overlooked and marginalized in policy processes, leading to low levels of support for the sector. The Voluntary Guidelines for Securing Sustainable Small-Scale Fisheries in the Context of Food Security and Poverty Eradication (the SSF Guidelines), adopted by the FAO Committee on Fisheries (COFI) in 2014, provide a policy framework for how to ensure sustainability for small-scale fisheries through a holistic and integrated approach. However, this transformational process needs substantial support to take place and be successful, which may be difficult to obtain in the absence of better data and information on the socio-economic contributions of small-scale fisheries. For this reason, a new study has been proposed by FAO and WorldFish to build upon the 2012 World Bank, FAO and WorldFish Center report Hidden Harvest: The Global Contribution of Capture Fisheries. The new study would deepen the knowledge and encourage data-sharing on small-scale fisheries and their socio-economic contributions, and also aim to make policy- and decision-makers aware of the sector's importance.

In order to plan this new global study on small-scale fisheries, an expert workshop was organized to develop: (i) the scope and main content of the new study, including type of data (indicators) to be collected and subsector coverage; and (ii) the methodologies for data collection and analyses, including key partners and information sources. A background paper on the subject was prepared and circulated ahead of the workshop (see Annex 5), which was held over three days in a format that featured thematic plenary presentations, three working group sessions, and plenary discussions.

The general and thematic expert presentations highlighted key areas for which data and information are needed; a number of data and information sources that could be used in the new study; and methodologies and tools that could be applied to better understand the socio-economic contributions of small-scale fisheries. These presentations were followed by working group discussions on data needs, as well as possible sources, methodologies and next steps for beginning the study. The discussions in the plenary as well as the working groups demonstrated both the theory and practice of measuring the socio-economic contributions of small-scale fisheries, reflecting the wide array of experience and research among the participants.

While the details of the workshop conclusions and recommendations may be found in the body of the report, the main points that emerged from the discussions are as follows:

1. The objective of the new study was two-fold:

a. to illuminate the hidden contributions of small-scale fisheries to the three dimensions of sustainable development - social, economic and environmental - 
as well as governance, quantifying these contributions to every extent possible, and estimating both the current and potential contributions (where feasible);

b. to identify the key threats to these contributions (both external and internal), and/or opportunities to enhance them, creating a narrative including key variables that can be quantified.

2. The main content of the study should also focus on:

a. the context of small-scale fisheries, including the policy context created by the Sustainable Development Goals (SDGs) and the SSF Guidelines, as well as measures of small-scale fisheries along a continuum reflecting the level of industrialization;

b. recommendations for raising awareness and providing appropriate support; and

c. recommendations for future research (to fill gaps in the "wish list").

3. It was agreed that the study's scope would cover both inland and marine small-scale fisheries, but would also encompass both developing and developed countries (with information disaggregated for both, and also for indigenous peoples) and include an updated "Thomson Table" for sake of comparison with large-scale fisheries (the Thomson Table shows a comparison between small- and large-scale fisheries, and was originally published in the ICLARM Newsletter in July 1980).

4. The target audience would be (i) policy- and decision-makers both in fisheries and beyond, and at national and decentralized levels, in order to raise awareness and increase appropriate support for small-scale fisheries; and (ii) small-scale fisheries advocates such as civil society organizations and other fisherfolk organizations, researchers, Non-governmental Organizations, etc.

5. The workshop participants agreed on the importance of early and frequent communication of study objectives and results in order to move towards engagement and ownership of the process and product, thus ensuring the target audience is reached and objectives are achieved.

6. The workshop proposed a wish list of variables or indicators to be measured in order to better understand the socio-economic contributions of small-scale fisheries, noting that even where data is not yet available, such a list may help drive future research.

7. The workshop participants agreed that the new study would not include primary data collection, but highlighted a number of new global data sets available since the 2012 Hidden Harvest study.

8. The workshop recommended a mixed-methods approach, essentially weaving together various data sources into a coherent and clear picture. Where global data sets are not available, case studies would provide information that could be extrapolated to global estimates, and/or illustrate global findings and data sets.

9. The workshop concluded by highlighting the next steps, which would include a study design based on this workshop (conceptual framework and methods to be used), to be completed by the end of 2017; the continuation of ongoing communication and partnerships to carry out the study collaboratively; and launch of the research in early 2018, with a target for completion in the first half of 2019. 



\section{Background to the workshop}

Small-scale fisheries play an important role in contributing to food security, nutrition, livelihoods, and local and national economies. However, there is limited data and information available on this contribution, and hence small-scale fisheries tend to be overlooked and marginalized in policy processes, leading to low levels of support for the sector. The Voluntary Guidelines for Securing Sustainable Small-Scale Fisheries in the Context of Food Security and Poverty Eradication ${ }^{1}$ (SSF Guidelines), adopted by the FAO Committee on Fisheries (COFI) in 2014, provide a policy framework for how to ensure sustainability for small-scale fisheries through a holistic and integrated approach; however, this transformational process needs substantial support to take place and be successful.

In 2012, the World Bank, FAO and WorldFish Center published Hidden Harvest: The Global Contribution of Capture Fisheries. ${ }^{2}$ This was a review of the economic importance of fisheries focusing in particular on employment, catches and GDP, and distinguishing between small- and large-scale fisheries, and likewise marine and inland fisheries (in addition, a separate analysis of recreational fisheries was included). This publication has remained the only source of quantitative information on small-scale fisheries at an aggregate level. While providing important information and estimates that are still valid, the analyses would benefit from being refined and updated, and also by including additional dimensions of the contribution of small-scale fisheries to food security and nutrition, poverty reduction, and the three dimensions of sustainable development more broadly. It should also be noted that the 2012 Hidden Harvest study was carried out before the SSF Guidelines were adopted, and therefore could not be framed within this context.

Accordingly, it was proposed that the Hidden Harvest study be revisited and updated to deepen the knowledge on small-scale fisheries and to provide a comprehensive and authoritative snapshot of their role and contribution, ultimately drawing the attention of policy- and decision-makers to the sector's importance.

An expert workshop was organized to develop and agree on:

- the scope and main contents of the new study, including type of data (indicators) to be collected and subsector coverage; and

- the methodology for data collection and analyses, including key partners and information sources.

The workshop was held at FAO in Rome, Italy, on 27-29 June 2017. The participants included some 40 experts on data sources and assessment methodologies in relation to the different dimensions of small-scale fisheries addressed by the SSF Guidelines; FAO staff participated as well (see list of participants in Annex 1).

The three-day workshop conducted in English included plenary presentations and discussions, and also several working groups for participants to discuss in smaller groups. The workshop agenda is attached as Annex 2.

1 Available at www.fao.org/3/a-i4356e.pdf.

2 Available at https://openknowledge.worldbank.org/bitstream/handle/10986/11873/664690ESWOP 1210120HiddenHarvest0web.pdf? sequence $=1$. 


\section{Introductory session}

\section{OPENING STATEMENT}

Mr Árni Matbiesen, Assistant Director-General (ADG), FAO Fisheries and Aquaculture Department

Mr Mathiesen welcomed the participants and highlighted the global importance of small-scale fisheries, while noting at the same time that information on the sector is limited. He stated that all have a role in improving the data and understanding of smallscale fisheries, and welcomed the workshop's effort toward that end. Since the 2012 Hidden Harvest study, new international policy frameworks have been established, notably the SSF Guidelines and the Sustainable Development Goals. With this changed context, Mr Mathiesen reiterated that better information is needed now on small-scale fisheries, and for this reason FAO and WorldFish have proposed a new and updated study to get a fuller and more accurate picture of small-scale fisheries. He stated that the objectives of the workshop were to design the scope and content of the new study, which will depend on partnerships and broad collaboration in order to be successful. He then closed by thanking existing partners, including Norway for its support to the implementation of the SSF Guidelines, as well as for this workshop. The full text of the opening remarks is presented in Annex 3.

\section{INTRODUCTION TO THE SSF GUIDELINES}

\section{Ms Nicole Franz, FAO}

Ms Franz reiterated the objectives of the workshop: to bring together a broad group of experts with knowledge on small-scale fisheries to inform a revision and update of the 2012 Hidden Harvest study and deepen the knowledge of small-scale fisheries. The new study would aim to provide a comprehensive and authoritative baseline on the role and contribution of small-scale fisheries, based on reliable, validated data and information, in order to draw the attention of policy- and decision-makers (as well as advocates for small-scale fisheries) to the sector's importance. The assumption was that this information would support advocacy for adjusted or more balanced policy, appropriate investment, and strengthened governance in the sector (including its interactions with larger-scale fisheries). Ms Franz stated that at the end of the workshop, the hope would be to have clear ideas on (i) the scope and main contents of the new study, including type of data (indicators) to be collected and subsector coverage; and (ii) the methodology for data collection and analyses, including key partners and information sources.

Ms Franz suggested that, while working towards concrete workshop results and recommendations, participants should consider the workshop as a brainstorming exercise. She noted that the group of participants was not an exhaustive one, and that additional experts and researchers may contribute to the development of the study at a later stage. 


\title{
REFLECTION AND RECAP ON THE 2012 HIDDEN HARVEST PROCESS AND OUTCOMES: STRENGTHS, WEAKNESSES AND LESSONS LEARNED
}

\author{
Mr David Mills, WorldFish, and Ms Lena Westlund, FAO
}

Mr Mills presented an overview of the work conducted for the 2012 Hidden Harvest study. Case studies were constructed in diverse ways across selected countries, but with a common goal of filling out a "Big Numbers" table with the best available data from a range of sources and estimates. It was found to be critical to identify the right individual or institution to lead the case study, as data were often very disparate and held by a diverse range of institutions. Mr Mills used the examples of Bangladesh and Viet Nam to further explain the work that was carried out.

In Bangladesh, a household income and expenditure survey (HIES) was conducted in great detail, which provided a very good basis for estimating and extrapolating expenditure and consumption information. Data held in the FAO-established Fisheries Resources Information System were analysed for the first time. The Flood Action Programme had collected detailed data on commercial and subsistence fishery participation and catch by household in almost half the provinces of the country. A combined "like-with-like" and "nearest neighbour" approach was used to extrapolate these statistics to national estimates.

In Viet Nam, extensive fish consumption data from the Mekong River (available through the Mekong River Commission and a number of published reports) provided a basis for estimating production. Uncertainties regarding aquaculture production and local consumption of cultured fish were a complicating factor in estimates. A series of provincial studies in the Mekong also provided additional data. For marine systems, the Research Institute for Marine Fisheries in Hai Phong had completed a series of provincial studies that had not been incorporated into national statistics. Data from a published report re-estimating trash fish production was also incorporated.

The importance of considering the type of data and collection methodology when providing extrapolations was highlighted. For example, fish consumption data tends to be fairly normally distributed, and therefore not many samples are required to describe the shape of this consumption curve. However, fish capture statistics tend to be quite varied, with a large number of fishers catching a small number of fish, and a small number of fishers taking a much bigger catch. The shape of this curve will be unique to each situation, requiring a greater number of samples to describe what may be a unique curve (see Figure 1).

FIGURE 1

Theoretical representation of distributions of catch and consumption data

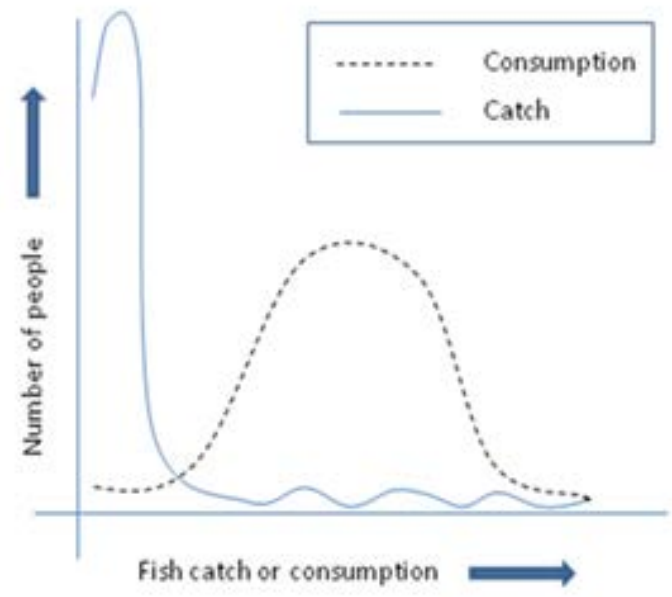


It could be argued that the Hidden Harvest report received only modest citation rates. The collective output from the project (the report, a book chapter and a primary paper) received just over 200 citations traceable through online searches. The most cited figures were the gender estimate (47 percent of the fisheries workforce are women), the comparison between large- and small-scale participation ( 90 percent in the smallscale sector), and the recreational fishing participation estimate (200 million people worldwide). It was noted that the final report received no "push" from the World Bank as it was released, and even the authors were unaware of its final release. Better and more transparent presentation of data, concerted efforts to ensure data has confidence limit estimates, and a well-developed communications strategy will be important for the new report.

Ms Lena Westlund of FAO continued the presentation by explaining in more detail the data compilation, analyses and extrapolations that had been made (based on the case studies) to arrive at the aggregate global figures for small- and large-scale fisheries in the 2012 Hidden Harvest study. ${ }^{3}$ She explained that, depending on the availability of data and the scale and complexity of the local situation, the different case studies had generated somewhat different results with regard to level of detail and depth. In many cases, it was necessary to complement the case study data with other sources of information, including from FAO Fisheries Country Profiles (FCPs), other FAO sources, published material and grey literature.

A first step in the data compilation and analysis was to prepare a summary table for each case study (country) including the following information (presented in Table 1).

TABLE 1

Template for compilation of information from case studies (2012 Hidden Harvest study)

\begin{tabular}{|c|c|c|c|c|c|c|c|}
\hline \multicolumn{8}{|c|}{ Definition of small-scale fisheries } \\
\hline & \multicolumn{3}{|c|}{ Small-scale fisheries (SSF) } & \multicolumn{3}{|c|}{ Large-scale fisheries (LSF) } & \multirow{2}{*}{ TOTAL } \\
\hline & INLAND & MARINE & TOTAL & INLAND & MARINE & TOTAL & \\
\hline \multicolumn{8}{|l|}{$\begin{array}{l}\text { Employment: } \\
\text { Number of fishers / } \\
\text { number of other jobs } \\
\text { Men / women }\end{array}$} \\
\hline $\begin{array}{l}\text { Production and } \\
\text { utilization: } \\
\text { Total annual catch } \\
\text { (quantity / value) } \\
\text { (landings by flag States) }\end{array}$ & & & & & & & \\
\hline $\begin{array}{l}\text { Contribution to animal } \\
\text { protein intake } \\
\% \text { of catch used } \\
\text { for local human } \\
\text { consumption }\end{array}$ & & & & & & & \\
\hline Efficiency: & & & & & & & \\
\hline Catch / fisher & & & & & & & \\
\hline $\begin{array}{l}\text { Fish caught / fuel used } \\
\text { Discards }\end{array}$ & & & & & & & \\
\hline
\end{tabular}

The tables were included in the preliminary report of the Big Numbers Project published in $2008^{4}$ (except GDP, which was added later). Based on this information, global estimates were calculated. This was done in a pragmatic way, using Excel,

3 The information on recreational fisheries and GDP in the 2012 Hidden Harvest had been added separately at a later stage after the case studies.

4 See Big Numbers report at http://pubs.iclarm.net/resource_centre/Big_Numbers_Project_ Preliminary_Report.pdf. 
rather than on the basis of ensuring statistical representation, as this was beyond the possibilities of the study given available resources.

The analysis focused on developing countries, and the first level of analysis was done at a regional level: Africa, America, Asia and Oceania. Examples of methods used include:

- Catch estimates: Case study catch figures were compared with FAO FishStat Plus data (2004-2006 averages). Most case study countries showed larger catches than reported, and other countries were adjusted accordingly.

- Ratio of small-scale to large-scale fisheries: Case study country data were used as given, and the ratio in other countries was assumed to be the same as the average of the case studies, i.e. 70 percent small-scale fisheries in the marine sector and 98 percent in inland waters. However, there were many alternative estimates made based on other available information.

- Direct employment: Case study country data were used as given, and estimates for other countries were made using the average annual catch rates (tonne/fisher) of the case studies, complemented with other information when available.

Even with the pragmatic analytical approach that was taken, there were many challenges including the general lack of data and the varying quality of the different case studies, as well as questions with regard to how representative the case studies were in a global perspective (e.g. fishmeal-producing countries in Latin America were not included). Moreover, some dimensions that are essential to small-scale fisheries were not covered, such as food security and nutrition. Still, the 2012 Hidden Harvest study has remained the only source of quantitative information on small-scale fisheries at an aggregate level. The new study will however need to take a more robust and holistic approach.

\section{PRESENTATION OF BACKGROUND PAPER}

\section{Mr John Virdin and Mr Xavier Basurto, Duke University}

Mr Virdin and Mr Basurto presented the results of an inventory of existing data sources available since the 2012 Hidden Harvest study which might support this new effort (see full background paper in Annex 5). They began by presenting a "wish list" of variables or indicators of the socio-economic contributions of small-scale fisheries that would be ideal in order to form a clearer global picture of the sector. These variables or indicators were categorized as those relating to: (i) production and utilization, (ii) employment (full- and part-time), (iii) efficiency, (iv) economic contribution, (v) food security and nutrition, (vi) trade, (vii) environmental impacts, and (viii) institutional arrangements.

They described the data sources that may be available to measure these variables or indicators, including global data sets such as the FAO FISHSTAT database; the Sea Around Us Project (SAUP) database, with reconstructions of fish catch by national waters at the University of British Columbia; the database on spatial assignment of marine catch constructed by Prof. Reg Watson at the Institute for Marine and Antarctic Studies (IMAS); the Information System on Small-Scale Fisheries (ISSF) database hosted by the Too Big To Ignore (TBTI) network; and census data available from the UN Statistics Division. Additionally, the scientific literature on small-scale fisheries since 2011 was reviewed to find the number of empirical measurements of a range of variables indicating the socio-economic contributions of small-scale fisheries and 
the level at which they were taken. Ad hoc reviews of grey literature from FAO and WorldFish (among others) were carried out as well.

The results of the review of the scientific literature suggest that the wish list of indicators could be divided into three tiers: (i) available indicators based on repeating and updating the approach from the 2012 Hidden Harvest study; (ii) likely available indicators at large spatial scales in a number of cases, or potentially at the global level; and (iii) those where data is unlikely to be available.

The background paper and presentation were a starting point for discussion on the information targeted and available for a new study, and the broader objectives presented previously. Some of the suggestions on data and indicators that emerged in the plenary discussion included considering other dimensions such as infrastructure available for small-scale fisheries, as well as social aspects related to safety at sea and medical coverage.

Broader questions centred around:

- the target audience for a new study (i.e. where the demand is for this effort);

- the scope of the work (i.e. focus on both small- and large-scale or only the former, focus on both developing and developed countries or only the former, etc.);

- the methodology to be used; and

- the use of the term "baseline" in the description of the work (implying that the analysis will be repeated in the future).

Recommendations included:

- expanding gender-specific indicators;

- ensuring the scope extended to inland fisheries and defining the terms clearly (e.g. what the products are, what a "fish" is); and

- working with civil society organizations and the platform of the SSF Guidelines to help ensure wider communications and uptake of results than the 2012 Hidden Harvest study.

Additionally, the discussion recommended clearly identifying the theory of change for the new study as well as the impact on policy- and decision-makers.

\section{WHAT DO WE MEAN BY SMALL-SCALE FISHERIES?}

Ms Lena Westlund, FAO, Mr Simon Funge-Smith, FAO, and Ms Ratana Chuenpagdee, Too Big To Ignore (TBTI)

Ms Westlund introduced the issue of defining - or characterizing - small-scale fisheries. Already in 2003, the FAO Advisory Committee on Fisheries Research (ACFR) had concluded that there was no globally agreed definition, and suggested that it would even be inappropriate to formulate a universally applicable definition for a sector as dynamic and diverse as small-scale fisheries. ${ }^{5}$ The SSF Guidelines also refer to the sector as diverse and dynamic, as well as generally anchored in local communities and having historic links to adjacent fishery resources, traditions and values. The SSF Guidelines do not prescribe a standard definition of small-scale fisheries, but underline the need to ascertain which activities and operators are considered small-scale to ensure transparency and accountability in the application of the Guidelines, and to do so in

5 FAO. 2004. Report of the second session of the Working Party on Small-scale Fisheries. Bangkok, Thailand, 18-21 November 2003. FAO Fisheries Report No. 735. Rome. 
meaningful and substantive processes that are participatory, consultative, multilevel and objective-oriented (paragraph 2.4).

The 2012 Hidden Harvest study used context-specific definitions for small-scale fisheries. These definitions varied between case studies, using either existing (national) definitions or a specific definition agreed upon for the particular case study. Those countries that have a definition for small-scale fisheries usually define the sector based on vessel size, or operational distance from shore or level of mechanization; these criteria may not be sufficient or appropriate. There is also a lack of consideration of the post-harvest sector.

In 2004, the ACFR felt that it would be best to describe the sector on the basis of the range of characteristics that are likely to be found in any particular small-scale fishery. The 2012 Hidden Harvest study also included a table proposing general characteristics of categories of fisheries (see Table 2.2 on page 5 of the 2012 Hidden Harvest report) 6

Based on this table, Mr Simon Funge-Smith of FAO introduced a matrix approach for the characterization of diverse small-scale fisheries that could be an approach for the new study. This matrix allows a value to be assigned to each characteristic which can then be aggregated into an overall score, allowing for clearer disaggregation between large-scale fisheries and small-scale fisheries. The characteristics used for the index are primarily based on the same characteristics used in the 2012 Hidden Harvest study.

The difference between the index approach and tables of characteristics used earlier lies in the scoring approach and the fact that the cut-off between small-scale and large-scale fisheries is not absolute. For any specific fishery, the index approach uses scoring for each of the characteristics listed above. The score reflects the extent to which that particular characteristic is reflective of small-scale fishing or large-scale fishing in that fishery.

This index approach takes into account the variation in SSF between marine and inland waters as well as between developed and developing countries. The approach is in line with the recommendations of the SSF Guidelines to accommodate the tremendous variety of characteristics demonstrated by small-scale fisheries around the world.

The index approach also allows for considerable analysis and disaggregation between different types of small-scale fisheries. It was proposed that case studies undertaken as part of the new study could be characterized using this index approach, thus offering the opportunity for comparison or differentiation between differing small-scale fisheries. The presentation concluded that the development of this index could be further refined, potentially as a case study in its own right, although it was recommended that this should be undertaken before the other case studies proceed too far. A similar matrix could be developed for the small-scale post-harvest sector, using some of the same characteristics but also adding dimensions specific to post-harvest.

The proposed index is provided in Table 2.

6 The table was based on earlier work:

- Berkes, F., Mahon, R., McConney, P., Pollnac, R. \& Pomeroy, R. 2001. Managing small-scale fisheries. Alternative directions and methods. Ottawa, International Development Research Centre (IDRC). 309 pp.;

- Chuenpagdee, R., Liguori, L., Palomares, M.L.D. \& Pauly, D. 2006. Bottom-up, global estimates of small-scale marine fisheries catches. Fisheries Centre Research Reports, 14(8). University of British Colombia, Canada.;

- Johnson, D.S. 2006. Category, narrative and value in the governance of small-scale fisheries. Marine Policy, 30(2006): 747-756. 
TABLE 2

Proposed index for small-scale fisheries characterization

\begin{tabular}{|c|c|c|c|c|}
\hline Score & 0 & 1 & 2 & 3 \\
\hline $\begin{array}{l}\text { Size of fishing } \\
\text { vessel (or } \\
\text { equivalent range } \\
\text { for fixed gears) }\end{array}$ & No vessel & $<12 \mathrm{~m},<10 \mathrm{GT}$ & $<24 \mathrm{~m},<50 \mathrm{GT}$ & $>24 \mathrm{~m},>50 \mathrm{GT}$ \\
\hline Motorization & No engine & Outboard engine & $\begin{array}{l}\text { Inboard engine < } \\
\text { 400hp }\end{array}$ & Inboard > $400 \mathrm{hp}$ \\
\hline Mechanization & No mechanization & $\begin{array}{l}\text { Small power } \\
\text { winch/hauler } \\
\text { powered off } \\
\text { engine }\end{array}$ & $\begin{array}{l}\text { Independently } \\
\text { powered gear } \\
\text { deployment/ } \\
\text { hauling }\end{array}$ & $\begin{array}{l}\text { Fully mechanized } \\
\text { gear deployment } \\
\text { and hauling }\end{array}$ \\
\hline $\begin{array}{l}\text { Refrigeration/ } \\
\text { storage on board }\end{array}$ & No storage & Ice box & Ice hold & Refrigerated hold \\
\hline Labour/crew & $\begin{array}{l}\text { Individual and/or } \\
\text { family members }\end{array}$ & $\begin{array}{l}\text { Cooperative } \\
\text { group }\end{array}$ & $<2$ paid crew & $>2$ paid crew \\
\hline $\begin{array}{l}\text { Fishing unit/ } \\
\text { ownership }\end{array}$ & Owner/operator & $\begin{array}{l}\text { Leased } \\
\text { arrangement }\end{array}$ & Owner & $\begin{array}{l}\text { Corporate } \\
\text { business }\end{array}$ \\
\hline Time commitment & $\begin{array}{l}\text { Part-time/ } \\
\text { occasional }\end{array}$ & $\begin{array}{l}\text { Full-time, but } \\
\text { seasonal }\end{array}$ & Part-time all year & Full-time \\
\hline Day trip/multiday & $<6$ hours & Day trip & $<4$ days & $>4$ days \\
\hline $\begin{array}{l}\text { Fishing grounds/ } \\
\text { zone/distance } \\
\text { from shore }\end{array}$ & $\begin{array}{l}<100 \text { metres from } \\
\text { shoreline }\end{array}$ & $\begin{array}{l}<3 \mathrm{~km} \text { from } \\
\text { shoreline }\end{array}$ & $<20 \mathrm{~km}$ & $\begin{array}{l}>20 \mathrm{~km} \text { from } \\
\text { shoreline }\end{array}$ \\
\hline Disposal of catch & $\begin{array}{l}\text { Household } \\
\text { consumption/ } \\
\text { barter }\end{array}$ & Local direct sale & Sale to traders & $\begin{array}{l}\text { Onboard } \\
\text { processing and/ } \\
\text { or delivery to } \\
\text { processors }\end{array}$ \\
\hline $\begin{array}{l}\text { Utilization } \\
\text { of catch, } \\
\text { value added/ } \\
\text { preservation }\end{array}$ & $\begin{array}{l}\text { For direct human } \\
\text { consumption }\end{array}$ & Chilled & Frozen & $\begin{array}{l}\text { Frozen/chilled for } \\
\text { factory processing } \\
\text { (for human } \\
\text { consumption or } \\
\text { fishmeal) }\end{array}$ \\
\hline $\begin{array}{l}\text { Integration into } \\
\text { economy and/ } \\
\text { or management } \\
\text { system }\end{array}$ & $\begin{array}{l}\text { Informal, not } \\
\text { integrated (no } \\
\text { fees) }\end{array}$ & $\begin{array}{l}\text { Integrated } \\
\text { (registered, } \\
\text { untaxed) }\end{array}$ & $\begin{array}{l}\text { Formal, integrated } \\
\text { (licensed, landing } \\
\text { fees) }\end{array}$ & $\begin{array}{l}\text { Formal, integrated } \\
\text { (licensed, taxed) }\end{array}$ \\
\hline
\end{tabular}

Ms Ratana Chuenpagdee of the Too Big To Ignore (TBTI) network presented the TBTI Information System on Small-Scale Fisheries (ISSF) and how to consider the characteristics of small-scale-fisheries in terms of what we want and need to know about small-scale fisheries. The ISSF is the first interactive global repository of small-scale fisheries, providing information on key characteristics of this sector in various locations around the world, as well as synthesized knowledge about its importance, contributions and potential. The SSF profile layer in ISSF, in particular, asks contributors to provide either an official definition of small-scale fisheries or the "local" definition. Contributors are also asked to describe small-scale fisheries following the "20 questions" template (see Figure 2). 
FIGURE 2

ISSF question template

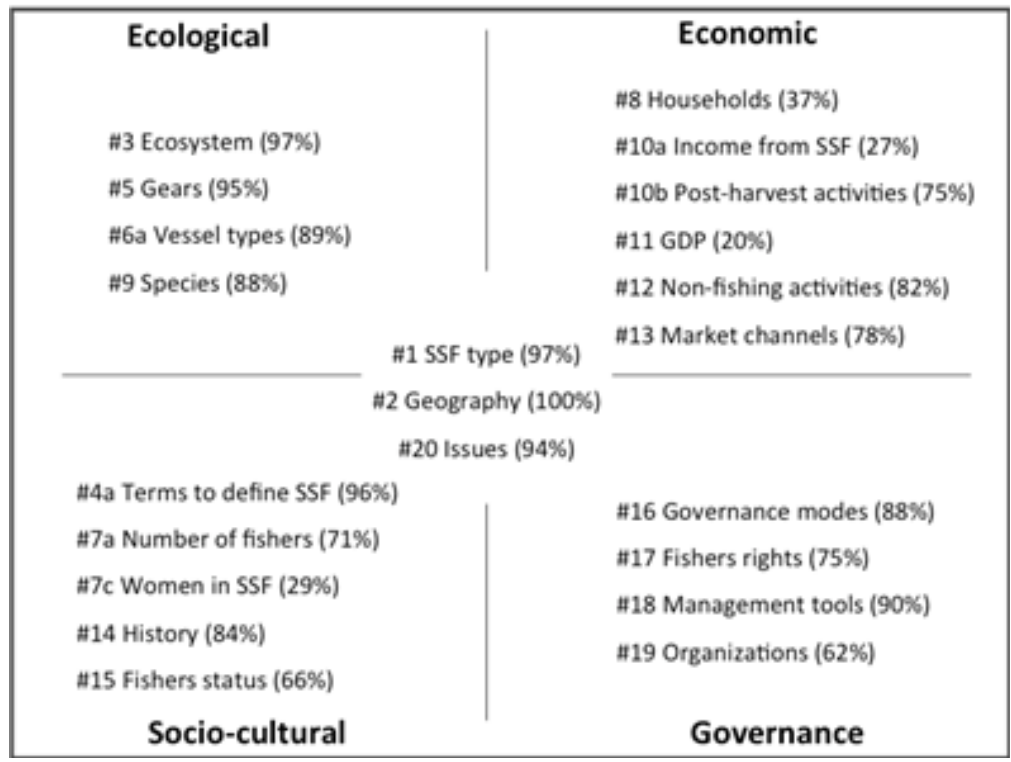

Note: \# indicates the question number and the percentage shows completion level of each question.

Currently, there are about 170 profiles in ISSF, covering over 40 countries around the world. This allows for analysis looking at how small-scale fisheries are defined and what characteristics describe SSF in these locations.

\section{COMMENTS AND DISCUSSION}

Subsequent to the presentations, the workshop discussion suggested the proposed index is a useful contribution, while noting challenges of multiple co-linearity and asking how much correlation exists between different characteristics, as well as questions related to inclusion of post-harvest activities and the need for a post-harvest indexing of similar characteristics. The discussion also noted that some characteristics may be missing from the current list in the index, e.g. "way of life" for participants. Additionally, participants suggested that including developed countries in the scope of a new study may include more advocates for small-scale fisheries, and highlighted that even within countries there will likely be a wide range of small-scale fisheries characteristics. 


\section{PLENARY PRESENTATIONS}

\section{Key areas for which data and information are needed}

UPDATING THE FAO ASSESSMENT OF THE STATUS OF INLAND FISHERIES

Mr Simon Funge-Smith, FAO

Mr Funge-Smith introduced the ongoing commitment of FAO to improve global understanding of the role and value of inland fisheries. The FAO Fisheries Resources Branch (FIAF) produces a periodic publication entitled "The State of Inland Fishery Resources” (SOIFR) every 5-7 years, with the last version published in 2011. It is now time to produce an update; however, a different approach is to be used. Previous SOFIR have traditionally focused on trying to analyse the FAO inland fishery statistics and the attempt to derive some trends for inland fisheries in the major river basins around the world. They have also covered thematic issues relevant to inland fisheries. The updated SOIFR seeks to go beyond the analysis of trends in production and provide a deeper analysis of the state of inland fishery resources and their importance/relevance to the achievement of the Sustainable Development Goals (SDGs), in particular SDG 6 and SDG 15. It aims to improve global understanding and appreciation of the contribution of inland fisheries to food security and human nutrition, ecosystem services, and biodiversity resources and livelihoods (in addition to other services such as employment and inclusive growth). The updated 2017 SOIFR therefore seeks to:

- quantify global inland fisheries resources in terms of food production, nutrition, employment and economic contribution, and to which countries/ regions or subnational areas they are important;

- provide values of what might be lost as a result of impacts, drivers and poor management, as well as the potential replacement cost of these (in terms of dollars, other resources such as land and water, feed, labour, etc.);

- provide updated discussion on ways to measure and assess inland fisheries, in particular how to try to more accurately establish inland fishery production in the many situations where there are challenges to gathering production statistics; and

- indicate the interactions between inland fisheries and management of water for other purposes.

These objectives are also in line with the objectives of the update of the 2012 Hidden Harvest. Since the vast majority of inland fisheries are in fact small-scale, there is 
considerable commonality between the objects of the SOIFR 2018 and the updated Hidden Harvest. The SOFIR 2018 will provide a quantitative picture of global inland fisheries, which will contribute a baseline for further detailed case studies and other work which is foreseen under the Hidden Harvest update. The presentation covered the contents of the updated SOIFR and pointed out some clear gaps that might be filled with specific case studies or modelling efforts.

\section{ASSESSING COASTAL FISHERIES}

\section{Mr Nicolas Gutierrez, FAO}

Mr Gutierrez provided an overview of the work under the Coastal Fisheries Initiative funded by the Global Environment Facility $(\mathrm{GEF})^{7}$ on developing an instrument to assess the social, environmental and economic performance of fisheries, notably in those that are data-limited, such as small-scale fisheries. This assessment instrument will be informed by the SSF Guidelines, and will also likely build upon existing instruments such as the Fisheries Performance Indicators, ${ }^{8}$ the toolbox for the Ecosystem Approach to Fisheries developed by FAO, and standards/assessments by the Marine Stewardship Council (MSC), among others. Toolkits and manuals for application of the instrument are planned in order to help ensure that they are widely used. Mr Gutierrez stressed that the assessment instrument is being designed to capture the three dimensions of sustainable development, with a module focused on data-limited fisheries. He noted that this instrument would help monitor implementation of the SSF Guidelines, as well as the contribution of coastal fisheries to the SDGs.

\section{FRAMEWORKS FOR ASSESSING LOCAL-LEVEL CONSERVATION AND STEWARDSHIP IN SMALL-SCALE FISHERIES}

\section{Mr Tony Charles, St. Mary's University, Canada}

Mr Charles began by stating that in seeking to highlight the "hidden harvest" of SSF, it is crucial to adopt an approach that embraces a "big picture", going well beyond fish harvests per se to recognize the much broader contributions of SSF in terms of economic, social, cultural and conservation benefits. He emphasized a major area of contribution provided by small-scale fishers in many parts of the world - that of undertaking environmental and fishery conservation measures. This includes involvement in protecting coastal and marine habitats, and also engaging in practical conservation measures both within the fishery and in coastal communities. Small-scale fishers also contribute local knowledge of aquatic ecosystems that is crucial to conservation success and to applying the Ecosystem Approach to Fisheries. All of these conservation benefits, currently being documented by the Community Conservation Research Network (www.CommunityConservation.Net), reflect important "stewardship feedbacks" that support the coastal economy and society. Such stewardship in fact provides benefits that scale up from the local/community level to regional/subnational, national and global levels.

Mr Charles outlined a number of analytical frameworks useful for assessing the role of local-level conservation and stewardship in small-scale fisheries. Further, he noted that recognition of this stewardship contribution, within a big picture perspective on

7 See www.thegef.org/topics/coastal-fisheries-initiative.

8 See: Anderson et al. 2015. The fishery performance indicators: a management tool for triple bottom line outcomes. PLOS ONE, 10(5). 
small-scale fisheries, can be extended to other contributions, such as (i) non-fishery benefits that accrue through the added value provided to the tourism sector from the existence of attractive small-scale fishing boats and wharf facilities on many coastlines; and (ii) support for social and cultural benefits provided by small-scale fisheries, including enhanced indigenous values, social stability, and an "engine" of the coastal economy. Maintaining conservation and other services provided by SSF requires that policy-makers address the external threats faced by these fisheries, in order to rectify problems of misguided access, governance and economic policies, as well as to improve responses to climate change.

\section{COMMENTS AND DISCUSSION}

In the discussion that followed both presentations, questions were raised about complementarity and/or overlap with the Ocean Health Index, ${ }^{9}$ which many countries have committed to using at the national level, and in some cases is now being used at the provincial level. Mr Gutierrez noted that this index may be considered as a tool for the proposed study, and also that many of its indicators will be captured in the case of the instrument under development for the Coastal Fisheries Initiative. Mr Charles also reiterated the importance of using multiple approaches in small-scale fisheries, notably to capture the stewardship services they often provide. Participants noted that some aspects of small-scale fisheries, such as poverty alleviation, cannot be measured without also looking at other sectors outside of the fisheries. Finally, participants noted that the Pacific Community (SPC) will be releasing a dashboard monitoring the status of inshore fisheries in the Pacific Islands, based on creel surveys.

9 See www.oceanhealthindex.org. 


\section{Data/information, sources and methodologies that can be useful for the new study}

FAO GLOBAL STATISTICS, DATA FRAMEWORKS AND ONGOING EXPERIENCE

Ms Jennifer Gee and Mr Mark Dimech, FAO

Ms Gee and Mr Dimech delivered a joint presentation summarizing the current state of global statistics databases hosted at FAO as well as ongoing project work. Databases on capture, aquaculture and global production; food balance sheets; commodities and trade production; and fleets and fishers were all highlighted, along with the availability of online access to the data. ${ }^{10}$ Also outlined were the Fisheries and Resources Monitoring System (FIRMS) fishery inventories; publications such as The Value of African Fisheries and Handbook for Fisheries Socio-economic Sample Survey; and work on standard-setting and harmonization, with examples such as the Coordinating Working Party on Fishery Statistics.

The FAO EastMed project was raised as an example of the work being conducted since 2010 in the Mediterranean using a unified sampling methodology. The project has focused on capacity development for the collection and reporting of catch and effort, biological, fleet and socio-economic statistics in the eastern Mediterranean. Particular emphasis has been placed on the importance of using stratified random sampling across all of the data collection programmes.

\section{REVEALING THE SOCIO-ECONOMIC FEATURES OF SMALL-SCALE FISHERIES IN SOUTHEAST ASIA}

Mr Yuttana Theparoonrat, Southeast Asian Fisheries Development Centre (SEAFDEC)

Mr Theparoonrat presented a summary of SEAFDEC's efforts to measure and monitor the socio-economic aspects of SSF in southeast Asia, using a 2011-2012 survey in a sample of sites across seven countries (Cambodia, Indonesia, Malaysia, Myanmar, the Philippines, Thailand and Viet Nam). The survey effort began with a synthesis of existing studies or surveys on the number of small-scale fishers, vessels and metric tonnes of production. Results presented from the survey included:

- age distribution of small-scale fishers (with the majority between ages 41 to 60, though Cambodia and Indonesia showed younger participation);

- education levels of small-scale fishers (with the majority having attended at least primary and often secondary school);

- fishing as the primary and/or sole occupation of small-scale fishers (with most fishing exclusively, except for those in Cambodia);

- income levels (notably almost 80 percent of small-scale fishers measured in the

10 See www.fao.org/fishery/statistics/en. 
Philippines earned less than USD150 per month);

- debt levels and sources of financing for small-scale fishers (often commercial banks);

- level of motorization in the small-scale fisheries fleet (the majority using either inboard or outboard engines);

- licensing of small-scale fisheries vessels;

- type of gear utilized for small-scale fisheries harvesting (often gillnet);

- major problems perceived by small-scale fishers (most frequently cited were climate-related and/or illegal fishing);

- support needed as stated by small-scale fishers (microfinance and subsidies were most often reported);

- awareness of how state regulations apply to small-scale fisheries (e.g. registration and licensing);

- participation of small-scale fishers in the enforcement of compliance with applicable state regulations (very little was measured); and

- interest or willingness of small-scale fishers to find livelihoods outside of fishing, and the types of such livelihoods most likely to be pursued.

Mr Theparoonrat concluded by highlighting ongoing and planned efforts for SEAFDEC to continue to support member states in enhancing data collection and monitoring of socio-economic aspects of small-scale fisheries in the region.

\section{DATA COLLECTION METHODS FOR SMALL-SCALE FISHERIES}

\section{Mr Jeppe Kolding, University of Bergen}

Mr Kolding stated that collecting reliable and informative data from small-scale fisheries is notoriously difficult due to the often scattered distribution in inaccessible areas, with a multitude of seasonally shifting capture techniques targeting dynamic multispecies fish communities. ${ }^{11}$ He noted that traditionally, fisheries data on annual fish production, species composition, effort, etc., are collected by research officers and assistants from governmental research institutes. The methods are usually quite similar, and originate from proposals from the FAO Fisheries Division. ${ }^{12}$ The techniques used are mainly experimental gillnet for biological parameters and fishery independent data; frame surveys for inventories of all fish production factors; and catch and effort surveys for daily catches (in weight only) and effort data. These surveys are expensive and heavily dependent on available manpower and economical resources. The precision, accuracy, usefulness, and cost-efficiency of these methods have often been questioned; indeed, reliable landing statistics are a notorious problem in many small-scale fisheries. The much cheaper alternative to these methods is to use logbooks filled out by the fishers themselves; however, this method has repeatedly been questioned for accuracy and reliability due to the inability to cross-check and validate the reported data (and usually only by total weight).

Mr Kolding presented a simple variation of the traditional logbook methods, where the information to be collected by the fisher is kept at a minimum, but with a higher level of information which can be validated. For each fishing trip only the date, fishing method, and locality are recorded. For the catch, each individual fish caught 
is recorded for species (local name), mesh size in which it was caught, and the length to the nearest centimetre. As such, there is no need for weight as this can be easily estimated automatically from length-weight relationships (either estimated locally or obtained from FishBase, for example). Mr Kolding noted that the advantage of this simple method (which was developed and tested in the small-scale Bangweulu fishery) ${ }^{13}$ is that using information on length, gear and mesh size, the quality of the data can be validated by simply plotting the catch distributions by gear/mesh size. It is practically impossible for a fisher to record a normal (or log-normal) distribution in random order, so this gives a direct visual tool to validate the data. There is also a software program (Pasgear 2) developed that has been customized to handle this data with easy punching, automatic estimation of weights, data validation, and automatic effort tracking for calculating catch per unit effort (CPUE). ${ }^{14}$

\section{SUBSIDIES: SMALL- VERSUS LARGE-SCALE FISHERIES SUBSIDIES}

\section{Mr U. Rashid Sumaila, University of British Columbia}

Mr Sumaila first presented a summary of the University of British Columbia's recent analysis of the split of national amounts of fisheries subsidies between small- and largescale fisheries. Then he presented their new approach for determining the "degree of smallness of fisheries", which was based on the fisheries of British Columbia.

In terms of the analysis of subsidies, ${ }^{15} \mathrm{Mr}$ Sumaila reported that while small-scale fisheries land up to an estimated 50 percent of global landings, employ over 22 million people globally and directly support food security for millions of people, only 16 percent of the estimated global fisheries subsidies of US\$35 billion in 2009 were provided to the sector. Furthermore, subsidies that stimulate overcapacity go overwhelmingly to large-scale fisheries. This skewed allocation of the bulk of subsidies to the large-scale sector is detrimental to small-scale fisheries, as it makes them less viable economically. Mr Sumaila stated that efforts should be made in both large-scale and small-scale fisheries to convert capacity-enhancing (harmful) subsidies to beneficial ones, i.e. those that focus on social and ecological sustainability and ecosystem restoration. Such action will benefit global fisheries in the long run, making them more economically viable while also being a beneficial way to spend taxpayer dollars.

In terms of the degree of smallness in fisheries, ${ }^{16} \mathrm{Mr}$ Sumaila noted that the university's research had identified a list of reoccurring features of SSF reported in the literature, which capture physical, economic and social features of small-scale fisheries. Fisheries in British Columbia are diverse, and often regarded as being industrialized and large-scale when analysed in a global context. The university has found that commonly identified features of small-scale fisheries are present in British Columbia's fishing fleets to a varying degree. Aboriginal Food, Social and Ceremonial fisheries and all commercial fisheries in British Columbia are analysed to determine the presence or absence of each of these features. The results of this research create a gradient of fisheries from smallest to largest scale, indicating that many fisheries in British

13 See Ticheler, Kolding, and Chanda (1998).

14 For further information see the software which can be downloaded at www.iMr.no/forskning/ utviklingssamarbeid/eaf_nansen_programmet/pasgear_2/en, and the manual at www.academia. edu/2920326/Pasgear_2_Introduction_and_Manual.

15 See www.sciencedirect.com/science/article/pii/S0308597X1730177X.

16 See www.oceancanada.org/about/\#working-paper-gibson-sumaila. 
Columbia can be classified as small-scale. The qualitative nature of this framework creates an opportunity for any fisheries, anywhere in the world, to be compared.

\section{INDIGENOUS COASTAL COMMUNITIES}

\section{Ms Lydia Teh, Nereus Program hosted at the University of British Columbia}

Ms Teh's presentation covered two topics: (i) a global database of seafood consumption among coastal indigenous peoples (CIP), and (ii) assessing the socio-economic qualities of marine fisheries jobs.

The CIP database contains a global list of coastal indigenous groups, including their location, population and seafood consumption - where "seafood" refers to fish, invertebrates and other marine living resources. A total of 1900 individual communities and 600 groups, representing 27 million people across 87 maritime states, are recorded in the database. Coastal indigenous peoples encompass those groups living by the coast that are either legally recognized or that self-identify as being indigenous or belonging to an ethnic minority, as well as the population of small island developing states. Seafood consumption data were sourced directly from ethnographies, fisheries research, diet surveys, and other medical and health research. Globally, per capita indigenous seafood consumption was on average 15 times higher than in the corresponding countries. Ms Teh stated that this explicit quantification of CIP's reliance on seafood reinforces the need to recognize and support the contribution that indigenous fisheries make to culture and food security.

In terms of quantifying the contribution of marine fisheries to employment, Ms Teh stated that conducting such an effort in terms of the number of jobs does not provide information on the socio-economic value of that job (i.e. job quality) to the fisher. She noted that an examination of job quality is necessary to achieve relevant, socially centred policies for fisheries management. Ms Teh informed the group that the Nereus Program is starting to compile job quality indicators that relate to income sufficiency, social security and risk, among other variables. She showed preliminary results of income sufficiency, which was measured as the ratio of fishing job income to average income, and the ratio of fishing job income to poverty line income. She concluded by noting that their analysis so far indicates that across 54 countries, fishing income tends to be above national poverty lines but below average incomes. Data compilation is ongoing for this research.

CONSTRUCTING CONSUMPTION AGGREGATES FOR FOOD SECURITY ANALYSIS USING HOUSEHOLD INCOME AND EXPENDITURE SURVEYS FROM THE PACIFIC ISLAND COUNTRIES AND TERRITORIES

\section{Mr Michael Sharp, Pacific Community (SPC)}

Mr Sharp presented an overview of recent work to conduct household income and expenditure surveys (HIES) in the Pacific Islands, in order to update the pre-2009 per capita fish consumption (availability) estimates that were calculated in $2009 .{ }^{17} \mathrm{Mr}$ Sharp noted that new estimation methodologies, following those recommended by Deaton and Zaidi (2002), ${ }^{18}$ are being adopted, and per capita fish availability estimates will

17 Bell et al. 2009. Planning the use of fish for food security in the Pacific. Marine Policy, 33: 64-76. 18 Deaton, A. \& Salman, Z. 2002. Guidelines for Constructing Consumption Aggregates for Welfare Analysis. LSMS. Working Paper No. 135. World Bank. 
be disaggregated by: seafood source (cash purchased, subsistence and gifts received); fishery (pelagic, reef, invertebrate and canned); and geospatial location (urban and rural). The following countries are included in this study: Micronesia (Federated States of), Nauru, Palau, Samoa, Solomon Islands, Tokelau, Tonga and Vanuatu -8 of the 16 Pacific Island countries representing each Pacific subregion (Melanesia, Micronesia and Polynesia). An additional three countries - Cook Islands, Niue and Tuvalu - completed HIES in 2016 and are in various stages of data processing and reporting; this data will be available for inclusion in such a study by 2018 .

Mr Sharp stated that subsequent to the updated per capita fish availability estimates, an additional study reporting macro- and micronutrient availability from various sources, including fish and seafood, will be conducted in 2018. These studies are being conducted in collaboration with WorldFish, the University of Wollongong, FAO and SPC, with financial support provided by the Government of Australia through the Australian Centre for International Agricultural Research.

The HIES samples are designed to give nationally (and in most cases, subnationally) representative results, and are implemented with the primary objectives of updating the household component of national accounts, rebasing the consumer price index, and conducting an analysis of the prevalence of poverty. Recent methodological ${ }^{19}$ and empirical ${ }^{20}$ advances in the implementation of HIES, and analysis of associated data, have broadened the scope of HIES to make macro- and micronutrient availability estimates.

The SPC, in consultation with technical partners, has designed regionally standardized HIES instruments and methods, which are recommended for adoption by its 22 member countries and territories. Not all have adopted the regional recommendation, and there are some limitations in the use of those data that were collected independently of the regional standard. All HIES data collected in the Pacific are owned by the respective national statistical agency, and data access agreements are required prior to gaining access to the data.

Mr Sharp noted the numerous opportunities for the use of HIES data, including:

- estimating macro- and micronutrient availability;

- providing a significant representation of the Pacific region, having recently conducted HIES;

- establishing a regionally standardized methodology that follows recommendations by Fielder, Carletto and Dupriez (2012) ${ }^{21}$ in improving survey methods and instruments to conduct nutritional studies;

- disaggregation and/or cross-tabulation with various demographic and socioeconomic variables; and

- continued advances in the regionally standardized HIES, including computerassisted personal interviewing; design of new food classifications that match consumption classifications with food nutrition tables; the collection of opening and closing food stocks to improve consumption estimate accuracy; a new food-away-from-home module (a typically under-reported area); systems to eliminate volume estimation issues; and improved approaches to sampling design and data-processing and aggregation methods.

19 Fiedler, J.L., Carletto, C. \& Dupriez, O. 2012. Still waiting for Godot? Improving household consumption and expenditures surveys (HCES) to enable more evidence-based nutrition policies. Food and Nutrition Bulletin, 33(3): 242-251.

20 Bermudez, O.I., Lividini, K., Smitz, M.F. \& Fiedler, J.L. 2012. Estimating micronutrient intakes from household consumption and expenditures surveys (HCES): an example from Bangladesh. Food and Nutrition Bulletin, 33: 208-13.

21 Fiedler, Carletto and Dupriez, 2012. (Op. cit.) 
Despite these advances, Mr Sharp noted that numerous challenges remain in the application of HIES data for nutritional analysis, including:

- numerous food acquisition transactions reported in non-standard units of measurement, and small sample sizes limiting volume imputation;

- difficulty understanding intra-household food distribution, thus limiting understanding of individual (as opposed to household) access to nutrients;

- small sample sizes and limited spatially disaggregated market and consumer price data, which limit opportunities to derive spatial price estimates;

- sampling and non-sampling errors, such as respondent fatigue or providing insufficiently detailed information in reporting food types; and

- Pacific Island Countries and Territories (PICTs) not adopting recommended survey instruments and methodologies, which limits opportunities to conduct regionally comparable nutrition availability estimates.

In addition to HIES, Mr Sharp noted that there are a number of alternative data sources in the Pacific region that will positively contribute to the new study, including:

- a recent study titled "Fisheries in the Economies of the Pacific Island countries and territories", ${ }^{22}$ which provides catch estimates (volume and value), amount of fisheries contribution to GDP and export, information on government revenue, and employment and consumption estimates;

- regular fisheries-dependent data collection, such as creel, underwater visual census, and artisanal (tuna) catch and effort;

- project-specific data, such as Pacific Regional Oceanic and Coastal Fisheries Development Programme and other ad hoc project collections;

- regional industrial tuna fisheries, which are data-rich and well-reported;

- other sources, such as census, agricultural census, socio-economic surveys, trade, geospatial and health. The Coastal Fisheries Programme of SPC's Fisheries, Aquaculture and Marine Ecosystems Division has recently drafted indicators to annually report against in the Coastal Fisheries Report Card. The goals, outcomes, policy relevance and indicators within this report card are provided in Table 3. Mr Sharp noted that these indicators are in draft form (as of 4 July 2017) and are subject to amendment.

The Coastal Fisheries Programme of SPC's Fisheries, Aquaculture and Marine Ecosystems Division has recently drafted indicators to annually report against in the Coastal Fisheries Report Card. The goals, outcomes, policy relevance and indicators within this report card are provided in Table 3. Mr Sharp noted that these indicators are in draft form (as of 4 July 2017) and are subject to amendment.

22 Gillett, R. 2016. Fisheries in the economies of the Pacific Island countries and territories. Nouméa, Pacific Community (SPC). 
TABLE 3

SPC Coastal Fisheries goals, outcomes, policy relevance and indicators

\begin{tabular}{|c|c|c|}
\hline Outcomes & Policy relevance & Indicators \\
\hline \multicolumn{3}{|l|}{ Goal 1: Empowerment } \\
\hline $\begin{array}{l}\text { Informed, empowered } \\
\text { coastal communities } \\
\text { with clearly defined } \\
\text { user rights }\end{array}$ & $\begin{array}{l}\text { SSF Guidelines } 5 a \\
\text { FPO } \\
\text { AICHI Target } 1 \\
\text { SDG Indicator 14.b. } 1\end{array}$ & $\begin{array}{l}\text { - Number of PICTs where user rights for coastal } \\
\text { communities are formally recognized } \\
\text { - Ability of right holders to claim/control the use } \\
\text { of their rights } \\
\text { - Level of community awareness of the status of } \\
\text { their resources } \\
\text { - Level of community action to manage declining } \\
\text { resources }\end{array}$ \\
\hline $\begin{array}{l}\text { Adequate and } \\
\text { relevant information } \\
\text { to inform } \\
\text { management and } \\
\text { policy }\end{array}$ & $\begin{array}{l}\text { FPO } \\
\text { SAMOA Pathway } 58 . a \\
\text { MSG Roadmap } \\
\text { Objective } 2 \\
\text { Aichi Biodiversity } \\
\text { Target } 19\end{array}$ & $\begin{array}{l}\text { - Number and \% of coastal fisheries management } \\
\text { measures informed by evidence } \\
\text { - Number of fisheries extension officers (as a ratio } \\
\text { to total number of households participating in } \\
\text { fisheries and aquaculture) } \\
\text { - Coastal communities receiving information } \\
\text { relevant to coastal fisheries management (i.e. } \\
\text { coverage) } \\
\text { - Accessibility and appropriateness of information } \\
\text { available to inform community-based coastal } \\
\text { fisheries management }\end{array}$ \\
\hline $\begin{array}{l}\text { Recognition of, } \\
\text { and strong political } \\
\text { commitment and } \\
\text { support for, coastal } \\
\text { fisheries management } \\
\text { at a national and } \\
\text { subnational scale }\end{array}$ & FPO Indicator 7 & $\begin{array}{l}\text { - National recurring budgets allocated to coastal } \\
\text { fisheries (\% of total budget) } \\
\text { - Number of staff allocated to coastal fisheries, } \\
\text { both national and subnational (as a ratio to } \\
\text { total number of households participating in } \\
\text { fisheries and aquaculture) - disaggregated by } \\
\text { professional/support staff and gender }\end{array}$ \\
\hline $\begin{array}{l}\text { Refocused fisheries } \\
\text { agencies that } \\
\text { are transparent, } \\
\text { accountable and } \\
\text { adequately resourced, } \\
\text { supporting coastal } \\
\text { fisheries management } \\
\text { and sustainable } \\
\text { development, } \\
\text { underpinned by } \\
\text { CEAFM }\end{array}$ & $\begin{array}{l}\text { FPO } \\
\text { MSG Roadmap } \\
\text { Objective } 1.3 \\
\text { Aichi Biodiversity } \\
\text { Target } 2 \text { \& Target } 20\end{array}$ & $\begin{array}{l}\text { - Number of PICTs with published annual financial } \\
\text { statements for their national fisheries offices } \\
\text { (these would normally be included in annual } \\
\text { reports) } \\
\text { - National recurring budgets allocated to coastal } \\
\text { fisheries (\% of total budget, ratio to total } \\
\text { number of households participating in fisheries } \\
\text { and aquaculture) } \\
\text { - National coastal fisheries management roadmap } \\
\text { or strategy in place (current dates) }\end{array}$ \\
\hline \multicolumn{3}{|l|}{ Goal 2: Resilience } \\
\hline $\begin{array}{l}\text { Strong and up-to- } \\
\text { date management } \\
\text { policy, legislation and } \\
\text { planning }\end{array}$ & $\begin{array}{l}\text { FPO } \\
\text { SAMOA Pathway } 58 . \text { a } \\
\text { \& } 58.9 \\
\text { SDG Target } 14.4 \\
\text { MSG Roadmap } \\
\text { Objective } 3.1 \\
\text { SSF Guidelines } 10 \\
\text { Aichi Biodiversity } \\
\text { Target } 17\end{array}$ & $\begin{array}{l}\text { - Number of PICTs with current coastal fisheries } \\
\text { management policies } \\
\text { - Number of PICTs with current coastal fisheries } \\
\text { management legislation } \\
\text { - Evidence of coastal fisheries monitoring, control, } \\
\text { surveillance and enforcement (e.g. number of } \\
\text { recorded violations, fines, inspections) }\end{array}$ \\
\hline $\begin{array}{l}\text { Effective collaboration } \\
\text { and coordination } \\
\text { between stakeholders } \\
\text { and key sectors of } \\
\text { influence }\end{array}$ & $\begin{array}{l}\text { FPO Indicators } 12 \& 14 \\
\text { MSG Roadmap } \\
\text { Objective } 1.4\end{array}$ & $\begin{array}{l}\text { - Coastal fisheries management-related projects or } \\
\text { activities integrating more than one government } \\
\text { ministry } \\
\text { - Coastal fisheries management-related projects } \\
\text { or activities including multiple non-government } \\
\text { stakeholders } \\
\text { - Level of effectiveness of partnerships, } \\
\text { collaboration and coordination } \\
\text { - Fisheries statistics incorporated into the National } \\
\text { Strategy of the Development of Statistics (NSDS) }\end{array}$ \\
\hline
\end{tabular}




\begin{tabular}{|c|c|c|}
\hline Outcomes & Policy relevance & Indicators \\
\hline \multicolumn{3}{|l|}{ Goal 1: Empowerment } \\
\hline $\begin{array}{l}\text { More equitable } \\
\text { access to benefits } \\
\text { and decision-making } \\
\text { within communities, } \\
\text { including women, } \\
\text { youth and } \\
\text { marginalized groups }\end{array}$ & $\begin{array}{l}\text { FPO } \\
\text { SSF Guidelines } 8\end{array}$ & $\begin{array}{l}\text { - Labour force participation rate in fisheries } \\
\text { (disaggregated by age, gender, occupation and } \\
\text { education level) } \\
\text { - Household participation in fisheries and } \\
\text { aquaculture (disaggregated by urban/rural) } \\
\text { - Number and \% of women in senior fisheries } \\
\text { positions } \\
\text { - Number of women and men graduating in the } \\
\text { areas of fisheries management and sciences } \\
\text { - Number and \% of people attending meetings } \\
\text { where coastal fisheries management decisions } \\
\text { are made who are women and young people }\end{array}$ \\
\hline \multicolumn{3}{|l|}{ Goal 3: Livelihoods } \\
\hline $\begin{array}{l}\text { Monitoring of catches } \\
\text { to keep harvests } \\
\text { within sustainable } \\
\text { limits }\end{array}$ & $\begin{array}{l}\text { SSF Guidelines } 5 b \\
\text { Aichi Biodiversity } \\
\text { Targets } 4 \text { \& } 11 \\
\text { SDG Indicators } 14.2 .1 \\
\& 14.5 .1,14.4 .1 \\
\text { SAMOA Pathway 58.e } \\
\& 58.0 \\
\text { FPO } \\
\text { Micronesia Challenge }\end{array}$ & $\begin{array}{l}\text { - Coastal ecosystem and fisheries monitoring and } \\
\text { assessments undertaken (i.e. data collection) } \\
\text { - Stock status of key indicative coastal fisheries } \\
\text { species } \\
\text { - Percentage of PICT coastal areas under } \\
\text { management or protection }\end{array}$ \\
\hline $\begin{array}{l}\text { Diversified supply of } \\
\text { fish, primarily through } \\
\text { nearshore fish } \\
\text { aggregating devices } \\
\text { (FADs) and sustainable } \\
\text { aquaculture }\end{array}$ & $\begin{array}{l}\text { SDG Target } 14.7 \\
\text { SAMOA Pathway 58.b } \\
\text { \& 58.h } \\
\text { SSF Guidelines } 6 \text { \& } 7 \\
\text { MSG Roadmap } \\
\text { Objective } 3.2 \\
\text { FPO }\end{array}$ & $\begin{array}{l}\text { - Household income from fisheries \& aquaculture } \\
\text { (income includes cash and subsistence, } \\
\text { disaggregated by capture \& aquaculture; cash \& } \\
\text { subsistence; and urban \& rural) } \\
\text { - Proportion of households who sell fish } \\
\text { (disaggregated as above) } \\
\text { - Proportion of total household consumption } \\
\text { expenditure on fisheries (disaggregated by } \\
\text { fish type: fresh reef, pelagic or invertebrate; or } \\
\text { canned) } \\
\text { - Proportion of households who consume fish } \\
\text { (disaggregated as above) } \\
\text { - Location and fishing methods used by } \\
\text { households fishing (location disaggregated by } \\
\text { freshwater, inshore, nearshore, offshore, FAD; } \\
\text { gear disaggregated by net, spear, harpoon, hook } \\
\text { \& line, gleaning, traps) } \\
\text { - Volume \& income generated from nearshore } \\
\text { FAD fishing } \\
\text { - Proportion of households that participate in } \\
\text { fisheries that are below the national poverty line }\end{array}$ \\
\hline \multicolumn{3}{|l|}{ Goal 4: Food security } \\
\hline $\begin{array}{l}\text { Enhanced food } \\
\text { security from } \\
\text { sustainable fisheries, } \\
\text { including the supply } \\
\text { of tuna for domestic } \\
\text { consumption }\end{array}$ & $\begin{array}{l}\text { FPO } \\
\text { SDG Targets } 2.1 \& 3.4\end{array}$ & $\begin{array}{l}\text { Proportion of daily per capita calorie } \\
\text { consumption from fisheries (disaggregated by } \\
\text { fish type: fresh reef, pelagic or invertebrate; or } \\
\text { canned) } \\
\text { - Reported incidences of fish poisoning }\end{array}$ \\
\hline
\end{tabular}

\section{A BITE INTO THE NUTRITIONAL VALUE OF FISH}

\section{Christina Hicks, Lancaster University - presented by David Mills, WorldFish}

On behalf of Ms Hicks, Mr Mills of WorldFish presented an overview of progress from a research partnership involving Lancaster University, WorldFish, FAO and the University of Washington. The presentation stated that malnutrition can occur if people are not receiving sufficient protein and calories to sustain healthy functioning, but can also result from a lack of micronutrients - i.e. hidden hunger - the consequences of which are severe for individuals and for whole societies. These can include impaired 
brain development, infant mortality and childhood stunting, with children being ten times more likely to die from preventable diseases.

With this introduction, the presentation summarized research underway in the Solomon Islands and Timor-Leste, noting that a recent WorldFish study ${ }^{23}$ in the former found that only 5.8 percent of women achieved minimum dietary diversity meaning most women have diets inadequate in micronutrients - and also found that 33 percent of children aged 2 to 5 years exhibited stunted growth. Timor-Leste has the third highest global rate of childhood stunting (greater than 50 percent, attributed to protein and micronutrient deficiencies), and improved access to fish could make a significant contribution.

The presentation noted that, often, research into the role of fish in food security and nutrition "paints all fish with the same broad brush." However, FAO nutritionists point out that there can be very high variation in nutritional quality within the same given food type, and that "nutrient values may vary up to 1000 times among varieties of the same foods...." ${ }^{24}$ A recent study ${ }^{25}$ found that in Bangladesh, people had started eating more fish due to increased aquaculture production, but had decreased their intake of the wild caught species they had consumed previously. The study found significant decreases in iron and calcium intake from fish and an overall worsening of human nutrition.

The presentation noted that the variation in nutrient values for fish may be particularly relevant as some island communities shift away from consumption of reef fish from inshore capture fisheries towards monoculture aquaculture, or towards the consumption of pelagic species caught using fish aggregating devices (FADs), or where management measures are introduced that reduce the availability of small fish. The research currently underway aims to understand the nutritional consequences of such shifts, and ultimately how fisheries can be governed in ways that maintain or improve nutritional benefits. As a first step, the researchers determined the current knowledge base through a systematic review of the scientific literature and studies from the grey literature to understand nutrient measures by species of marine finfish. They focused on 14 nutrients critical to human health, and the presentation highlighted that data on vitamin A and vitamin B12 were particularly sparse - which is notable for the implications for reduced cognitive abilities of adults and children, and even mental retardation in children as well as infant mortality.

The presentation stated that the researchers collated over 4500 data points covering 424 marine finfish species. This databank represents a two-fold increase in the number of data points previously held by the global FAO INFOODS database, and will be donated to that existing data set for public use. The data is from 45 countries largely (83 percent) outside of the tropics (e.g. only 12 data points from within the Pacific Islands region), 70 percent of whom are considered at very high or high levels of human development, 20 percent from countries considered at medium levels of human

23 Unpublished data.

24 See www.fao.org/infoods/infoods/food-composition-challenges/en/.

25 See: Bogard, J.R., Farook, S., Marks, G.C., Waid, J., Belton, B., Ali, M., Toufique, K., Mamun, A. \& Thilsted, S.H. 2017. Higher fish but lower micronutrient intakes: temporal changes in fish consumption from capture fisheries and aquaculture in Bangladesh. PLOS ONE, 12(4): e0175098 (available at https://doi.org/10.1371/journal.pone.0175098). 
development, and only 3 percent from countries considered at lower levels of human development.

The researchers have only recently started to explore the data for variations in nutritional values between fish species, but noted preliminary results showing substantial variations in protein values and vitamin A quantities across all measures taken from muscle samples. The researchers are beginning to consider how well biological and ecological characteristics of species explain these variations. However, given these variations, there will be nutritional implications - both positive and negative - from shifts in fisheries management, trade, and development practice and policy.

The presentation concluded by emphasizing that this research represents a small fraction of the work underway on fisheries and nutrition, noting a new programme launched by WorldFish aiming to use fisheries and aquaculture to assist 3.5 million people to escape poverty and reduce the number of people suffering from micronutrient deficiencies. Additional aspects of research programmes underway include:

- understanding the impact of regional and international fisheries, health and trade policies;

- $\quad$ situating the role of fish among other diverse and dynamic attributes of diets;

- examining the way in which gendered roles, norms and relationships play into individual and household nutritional outcomes; and

- examining the local and international impacts of preference and cultures of consumption.

\section{SMALL-SCALE FISHERIES IN MOROCCO}

\section{Mustapha Oumarous, Institut National de Recherche Halieutique (INRH)}

Mr Oumarous presented the example of collecting data on small-scale fisheries in Morocco. He noted that in Morocco, small-scale fisheries have a major economic and social role in the fishing sector. Indeed, small-scale fishing occurs in more than 120 fishing areas along the Moroccan Mediterranean and Atlantic coasts at the main ports, fishing villages and beaches, and also on some shores with natural shelters. Approximately 15000 boats are engaged in this activity, generating more than 100000 direct and indirect jobs. The boats of this fleet are generally less than 3 gross registered tons (GRT) and deploy a multitude of gear types, using nets, hooks and traps that target different species in the shallow marine areas.

Mr Oumarous stated that different management measures are applied to support the country's small-scale fisheries and its development. In order to provide scientific information and advice to inform fisheries management, the National Institute of Fisheries Research (INRH) is implementing a specific programme to record operating and socio-economic indicators on small-scale fisheries. 


\section{WORKING GROUP SESSIONS}

\section{SESSION 1: WHAT DO WE WANT TO KNOW ABOUT SMALL-SCALE FISHERIES AND WHY?}

Ms Nicole Franz of FAO introduced the objective of this working session: to identify key data to include in the new study, in order to show the importance of SSF and the challenges they face. Then working groups (divided into marine fisheries, inland fisheries and pre-/post-harvest) were asked to prepare a wish list of data needed to meet the new study's objectives, and prioritize the variables to be used, drawing upon the table in the background paper (see Annex 5) and noting the rationale for the choice and target audience.

Each working group presented their results in plenary, and the discussions covered a range of topics, including:

- Organization of data to be collected - variables were categorized in terms of:

a. context;

b. current and (if possible) potential contributions to sustainable development (and further to its three dimensions [social, environmental and economic], though noting that contributions can be negative as well as positive, so the measurement would be current and potential net contributions); and

c. threats to these contributions.

- Variables vs indicators: The former will show contributions, and as noted could be both negative and positive from the perspective of small-scale fisheries. For this reason, variables will need to be translated into indicators of status (an example given of an indicator was the percentage of the population under the poverty line), with measures defined as good or bad (drawing from policy objectives such as the SDGs) or in net terms reflecting current measures in comparison to potential. Questions were also raised as to "whose value counts" in selecting variables and indicators.

- Informing policy-makers or establishing a baseline: The discussion suggested that the new study should aim at illustrating the socio-economic contributions of small-scale fisheries to policy-makers, rather than forming a baseline for monitoring. Policy-makers should include decentralized governments and their agents.

- Communicating results: The discussion emphasized the importance of an early plan to communicate the results to the targeted audience in order to impact policy, including consideration of both primary (i.e. policy- and decisionmakers) and secondary audiences (i.e. CSOs and advocates for small-scale fisheries), and how to translate data into messages for both. Towards this end, the discussion suggested including "bright spots" where threats to SSF are low or have been addressed proactively by decision-makers, as well as areas where the consequences of inaction can be seen.

- Consideration of inland fisheries in other sectors: The contributions of inland fisheries may be difficult to isolate in some instances, and may be reflected in 
measures of other sectors (e.g. tourism). For this reason, full value accounting (measuring the total economic value) of inland fisheries was proposed for consideration.

- Distinction between pre-harvest and harvest: Questions were raised as to how to distinguish between pre-harvest activities and harvest activities in small-scale fisheries (e.g. which inputs to measure, such as bait).

- Measures of ownership among small-scale fisheries operators: The question of ownership of fishing gear and equipment, as well as fishing vessels, was suggested as an important variable to measure in small-scale fisheries.

\section{SESSION 2: WHERE OR HOW CAN WE FIND THE DATA, AND WHAT METHODOLOGIES SHOULD WE USE FOR DATA COLLECTION AND ANALYSIS/ EXTRAPOLATION?}

Ms Franz introduced the objective of this working session: to assess the feasibility of obtaining the data required to measure the variables suggested on the first day, as well as the methodologies for doing so. The working groups continued to be divided into marine fisheries, inland fisheries and pre-/post-harvest, and considered a two-year time frame for the new study, focused on (i) where to find data (sources), (ii) methods for data collection/compilation, (iii) methods to extrapolate and at what level, and (iv) any suggested comparisons (including outside of the sector) in order to illustrate the context for the variable.

Each working group presented their results in plenary, and the discussions covered a range of topics building on the first session's focus on the variables to be measured ideally in order to meet the new study's objectives (i.e. the wish list of variables), including:

- Scope: Questions focused on whether or not the new study would include recreational fisheries, and also SSF in developed countries in addition to developing countries, noting in this latter regard the importance of the sector even in developed countries. Given the focus on the socio-economic contributions of small-scale fisheries, a new title of "Hidden Contributions" was suggested (or alternatively "Concealed Contributions"). The discussion on scope also noted that primary data collection was not foreseen in the new study, and hence the importance of identifying existing data available. The group recommended a focus on "need-to-know" data as opposed to "nice-to-know".

- Gender measures: Disaggregating gender in variables and measures will be a priority, and should be factored into the selection of case studies.

- Economic measures: Resource rent (defined as the surplus after costs) was discussed as to its applicability to small-scale fisheries, and suggested as one indicator (among others) to measure, without a potential or objective of maximization, but rather as a measure of economic viability in small-scale fisheries (i.e. whether small-scale fisheries operations are meeting their costs).

- Economic dependence: The economic multipliers from small-scale fisheries through input-output models were considered as a broader measure of their impact on a given economy (and, for example, the thought experiment of what would be the impact on an economy if small-scale fisheries were removed).

- Conservation measures: While relatively fewer variables were identified (though the example of multiple-use marine protected areas in Chile was suggested 
for further consideration), the need to determine appropriate measures was highlighted as further work to be conducted in design of the new study.

- Distribution of contributions: The discussion emphasized the importance of considering the distribution of various measures of contributions as well as the size.

- Climate change: The discussion noted that impacts of climate change on small-scale fisheries should be included in consideration of the measures of contributions.

- Food security: A priority area for research noted was the replacement cost of nutrition in the diets supported by small-scale fisheries.

- Waste: The discussion suggested a comparison of waste in small-scale fisheries and large-scale fisheries would be useful, though noting that a range of indicators are included in measures of waste, and would need to be disentangled.

- Governance: The discussion included measures of illegal, unreported and unregulated (IUU) fishing, and suggested a focus on illegal fishing, given that much of small-scale fisheries and particularly inland fisheries are unregulated.

- Classification of small-scale fisheries by "degree of smallness": The discussion recommended application of an index that highlights the differences in operational scale among small-scale fisheries (showing essentially a continuum of the level of industrialization in fishing), based on the index presented by Mr Funge-Smith and the research highlighted by Mr Sumaila.

\section{SESSION 3: SUGGESTED NEXT STEPS AND POTENTIAL PARTNERSHIPS}

Ms Franz introduced the objective of this working session: to conclude the discussions from the previous two sessions, and to suggest next steps for beginning the new study. The discussions in plenary included a range of topics and recommendations summarized previously, but also included:

- Finalizing the design of the new study: The group recommended using the input from the workshop to prepare an overall study design (based on data availability) that would include: a conceptual framework for the study highlighting societal and human well-being (the example of the design framework for the Caribbean Large Marine Ecosystem project was given); criteria for selection of case studies (noting that some case studies would be conducted in order to extrapolate global estimates, while others might be more isolated but illustrative of important contributions or threats); and linkages to the SSF Guidelines. A primary publication on the design and methods is currently planned over the remainder of 2017. 


\section{SUMMARY OF WORKING GROUP OUTCOMES AND PLENARY DISCUSSIONS}

Based on the working group sessions and the plenary discussions, a wish list of variables and indicators was produced as preferred measures of the socio-economic contributions of small-scale fisheries (pending data availability), here presented in Table 4.

TABLE 4

Consolidated list of potential indicators/variables to measure socio-economic contributions of small-scale fisheries

\begin{tabular}{|c|c|c|}
\hline Indicator/variable & Source of data & Notes \\
\hline \multicolumn{3}{|l|}{ Social contributions } \\
\hline 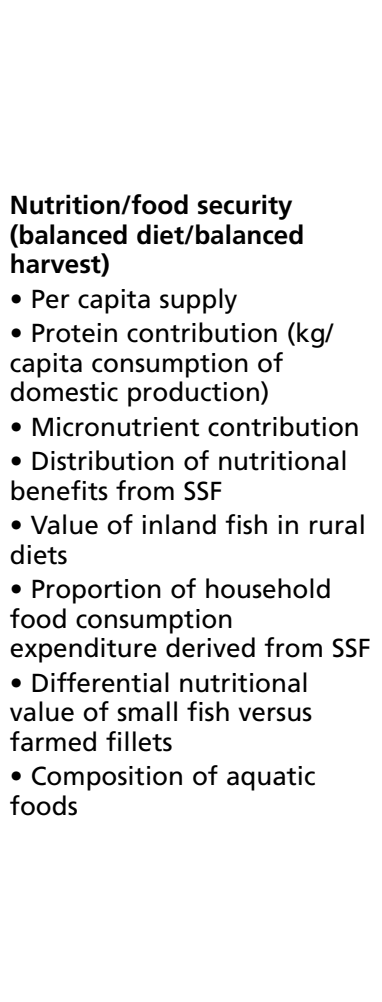 & $\begin{array}{l}\text { - Global food and fish } \\
\text { database (INFOODS). Data is } \\
\text { patchy (macronutrients, less } \\
\text { micronutrients and vitamins) } \\
\text { - HIES, income vs } \\
\text { consumption (consumption } \\
\text { by lower-income quintiles) } \\
\text { - Global Food Security index, } \\
\text { - Global Hunger Index } \\
\text { - FAOSTAT data } \\
\text { - Combination of household } \\
\text { consumption surveys } \\
\text { and consumption and } \\
\text { expenditure survey } \\
\text { - Cultural and size-related } \\
\text { factors in terms of assessing } \\
\text { edible portions }\end{array}$ & $\begin{array}{l}\text { - How much and what are people } \\
\text { eating? What is the micro- and } \\
\text { macronutrient contribution from SSF? } \\
\text { - Macro- and micronutrients include: } \\
\text { protein, iron, zinc, vitamin A, omega } \\
\text { 3, etc. } \\
\text { - Agricultural food policy } \\
\text { - How to feed growing populations } \\
\text { - Risks of loss of food security } \\
\text { - Costs } \\
\text { - Can fish really be replaced? } \\
\text { - Changing diets due to transition from } \\
\text { fishery to aquaculture } \\
\text { - Impact on diets from loss of fisheries, } \\
\text { e.g. through comparison with the } \\
\text { nutritional value of the nearest } \\
\text { substitute } \\
\text { - To show that the idea that "fish } \\
\text { can always be replaced" may be an } \\
\text { erroneous conclusion; presumes that } \\
\text { aquaculture can replace inland fish, } \\
\text { or greater agricultural and livestock } \\
\text { productivity will compensate for } \\
\text { loss of inland fisheries; this does not } \\
\text { account for consequent environmental } \\
\text { degradation and loss of services; } \\
\text { underlying question of long-term } \\
\text { sustainability. } \\
\text { - Proportion of household food } \\
\text { consumption expenditure measure } \\
\text { aims to highlight the role of SSF } \\
\text { related to income in poor populations }\end{array}$ \\
\hline
\end{tabular}




\begin{tabular}{|c|c|c|}
\hline Indicator/variable & Source of data & Notes \\
\hline $\begin{array}{l}\text { Sociocultural benefits } \\
\text { - Related variables: tenure, } \\
\text { including customary } \\
\text { conservation, subsidiarity } \\
\text { - Legal institutional } \\
\text { commitment to indigenous } \\
\text { fisheries and cultural services } \\
\text { and products }\end{array}$ & $\begin{array}{l}\text { - Coastal Indigenous Peoples } \\
\text { (CIP) database at the } \\
\text { University of British Columbia } \\
\text { - Different reports from } \\
\text { different regional bodies } \\
\text { (e.g. OSPESCA, Caribbean } \\
\text { Regional Fisheries } \\
\text { Mechanism, Latin American } \\
\text { Organization for Fisheries } \\
\text { Development [OLDEPESCA]) }\end{array}$ & $\begin{array}{l}\text { - What role do SSF play in sociocultural } \\
\text { values and vice versa (e.g. number of } \\
\text { cultural dishes where fish is used and } \\
\text { sourced from small-scale fisheries)? } \\
\text { - CIP database contains a global list } \\
\text { of coastal indigenous groups, their } \\
\text { location, population and seafood } \\
\text { consumption, where seafood means } \\
\text { fish, invertebrates and other marine } \\
\text { living resources. A total of } 1900 \\
\text { individual communities and } 600 \\
\text { groups, representing } 27 \text { million people } \\
\text { across } 87 \text { maritime states, are recorded } \\
\text { in the database. }\end{array}$ \\
\hline $\begin{array}{l}\text { Role of fishing livelihoods } \\
\text { and fisheries in social/political } \\
\text { stability } \\
\text { - Number of dependents } \\
\text { on direct and indirect SSF } \\
\text { employment } \\
\text { - Self-employed } \\
\text { - Diversified portfolio } \\
\text { - Potential for other } \\
\text { employment from fisheries } \\
\text { (e.g. tourism, cultural services) } \\
\text { - Percentage of fish in the } \\
\text { diet by income quartile }\end{array}$ & $\begin{array}{l}\text { Census data on average size } \\
\text { of fishery households }\end{array}$ & $\begin{array}{l}\text { - Lack of alternatives; inland fish } \\
\text { as a diversified/seasonal livelihood } \\
\text { strategy; contribution to resilience - } \\
\text { often hidden in national surveys and } \\
\text { agricultural studies } \\
\text { - Role of inland fish as a coping } \\
\text { strategy in times of crisis/hardship; } \\
\text { highlights the hidden role of fish as } \\
\text { a coping strategy; opportunities for } \\
\text { diversification and recreation } \\
\text { - Fisher mobility, particularly seasonal } \\
\text { mobility and rotational mobility; } \\
\text { comes with a range of social issues and } \\
\text { impacts, forced labour } \\
\text { - Potential for local tourism from } \\
\text { inland fisheries, cultural services } \\
\text { - Ownership, rights and tenure in a } \\
\text { changing economy } \\
\text { - Case studies: providing a livelihood } \\
\text { to a community creates conditions for } \\
\text { social and political stability (e.g. after } \\
\text { a period of economic decline/increased } \\
\text { unemployment, examine if there is } \\
\text { a change in employment in fisheries } \\
\text { versus other comparable sectors) }\end{array}$ \\
\hline \multicolumn{3}{|l|}{ Environmental contributions } \\
\hline $\begin{array}{l}\text { Environmental services } \\
\text { (full cost accounting, } \\
\text { including water accounting; } \\
\text { value of fisheries and the } \\
\text { services of water that } \\
\text { sustain water; contribution } \\
\text { to biodiversity [and thus } \\
\text { utilization] through sustained } \\
\text { systems) }\end{array}$ & & $\begin{array}{l}\text { - Sustain environmental quality; } \\
\text { prevent degradation } \\
\text { - Sustain/conserve biodiversity } \\
\text { - Stop impacts on inland fisheries for } \\
\text { water management } \\
\text { - Demand water allocation (maintain } \\
\text { environmental flows); where } \\
\text { to use water and how to justify } \\
\text { environmental values of water } \\
\text { - Require mitigation of impacts on } \\
\text { inland fisheries (hydropower, irrigation, } \\
\text { agricultural /industrial runoff); } \\
\text { adequately account for impacts on } \\
\text { fish supply outside of agricultural and } \\
\text { irrigation accounting } \\
\text { - Role of fish in nutrition; ensuring } \\
\text { that inland fisheries are adequately } \\
\text { incorporated into accounting methods }\end{array}$ \\
\hline $\begin{array}{l}\text { Carbon footprint } \\
\text { (greenhouse gas emissions) }\end{array}$ & Dalhousie University & $\begin{array}{l}\text { - (Inland) capture fisheries are } \\
\text { essentially a free service, and } \\
\text { also usually accessible to country } \\
\text { populations that have no recourse to } \\
\text { imports or to aquaculture } \\
\text { - Relative efficiency of inland fish in } \\
\text { terms of production, energy carbon } \\
\text { footprint, versus other production } \\
\text { systems } \\
\text { - Include also energy use in input } \\
\text { production and processing }\end{array}$ \\
\hline
\end{tabular}




\begin{tabular}{|c|c|c|}
\hline Indicator/variable & Source of data & Notes \\
\hline $\begin{array}{l}\text { Water quality requirements } \\
\text { for inland fisheries }\end{array}$ & & $\begin{array}{l}\text { - Benefits of clean water for both } \\
\text { humans (e.g. drinking water) and } \\
\text { fisheries } \\
\text { - Arguments for the mutual } \\
\text { interests of fisheries and ecosystem / } \\
\text { environmental quality } \\
\text { - Fish as an indicator of ecosystem } \\
\text { quality }\end{array}$ \\
\hline Conservation benefits & & $\begin{array}{l}\text { To be defined (e.g. conservation areas } \\
\text { managed by small-scale fishers, such } \\
\text { as Locally Managed Marine Areas } \\
\text { [LMMAs]) }\end{array}$ \\
\hline Land use & & \multirow{2}{*}{$\begin{array}{l}\text { What are the environmental impacts } \\
\text { of SSF supply chains and how does this } \\
\text { compare with the production of other } \\
\text { substitute foods? }\end{array}$} \\
\hline $\begin{array}{l}\text { Waste/food loss during } \\
\text { harvesting, processing and } \\
\text { storage }\end{array}$ & & \\
\hline \multicolumn{3}{|l|}{ Economic contributions } \\
\hline $\begin{array}{l}\text { Catch } \\
\text { (disaggregated by small- and } \\
\text { large-scale, marine vs inland, } \\
\text { and also percent utilized for } \\
\text { human consumption) }\end{array}$ & & $\begin{array}{l}\text { - Update from } 2012 \text { Hidden Harvest } \\
\text { - Percent utilized for human } \\
\text { consumption illustrates the tradeoff } \\
\text { between food and feed; efficiency; } \\
\text { keeping fish in the human nutrition } \\
\text { pathway; also the demand for } \\
\text { aquaculture feed may drive price for } \\
\text { inland fish in some fisheries } \\
\text { - The challenges to estimate inland } \\
\text { harvest from SSF, given how distributed } \\
\text { inland systems are and the limited } \\
\text { resources to monitor/manage; options } \\
\text { could include developing multiple } \\
\text { estimates and comparing the extent } \\
\text { to which predictions converge: } 1 \text { ) } \\
\text { household consumption models; } 2 \text { ) } \\
\text { productivity-effort-yield models (where } \\
\text { productivity can be remotely sensed); } \\
\text { 3) standard yield models for different } \\
\text { inland habitats }\end{array}$ \\
\hline $\begin{array}{l}\text { Employment } \\
\text { - Include labour } \\
\text { characteristics: } \\
\text { - Total workforce (total } \\
\text { employed disaggregated by } \\
\text { activity) } \\
\text { - Demographics (sex and age } \\
\text { by activity) } \\
\text { - Occupational pluralism (job } \\
\text { diversity/job opportunities } \\
\text { - i.e. how many jobs people } \\
\text { occupy) } \\
\text { - Opportunity cost of labour } \\
\text { - Labour exploitation (e.g. } \\
\text { undocumented people } \\
\text { working in boats, etc.) }\end{array}$ & $\begin{array}{l}\text { - National census crossed } \\
\text { with regional data more } \\
\text { disaggregated by sector (e.g. } \\
\text { OSPESCA, OLDEPESCA) } \\
\text { - International organizations } \\
\text { (e.g. FAO, International } \\
\text { Labour Organization [www. } \\
\text { ilo.org/global/research/global- } \\
\text { reports/weso/2015/lang--en/ } \\
\text { index.htm]) } \\
\text { - National fisheries agencies } \\
\text { - Technical reports and } \\
\text { academic papers } \\
\text { - Academic institutes } \\
\text { - For opportunity cost of } \\
\text { labour: bureau of labour } \\
\text { statistics, International } \\
\text { Labour Comparisons } \\
\text { - Sea Around Us Project }\end{array}$ & $\begin{array}{l}\text { - Update from } 2012 \text { Hidden Harvest; } \\
\text { disaggregate by gender } \\
\text { - Who and how many are employed } \\
\text { in pre- and post-harvest fisheries } \\
\text { activities, as well as harvest activities? }\end{array}$ \\
\hline $\begin{array}{l}\text { Net economic benefits/ } \\
\text { viability } \\
\text { - Resource rents } \\
\text { - Contribution to other } \\
\text { sectors }\end{array}$ & $\begin{array}{l}\text { - Sunken Billions study for } \\
\text { resource rents, disaggregated } \\
\text { between small- and large- } \\
\text { scale } \\
\text { - Economic multipliers, input- } \\
\text { output model } \\
\text { - UBC }\end{array}$ & $\begin{array}{l}\text { - Potential rents can be distributed to } \\
\text { other sectors; note: investment needed } \\
\text { to cover short-term costs before } \\
\text { recovery } \\
\text { - For input-output, can get basic value } \\
\text { at global level and get more detailed } \\
\text { information from case studies (e.g. } \\
\text { upstream multipliers) }\end{array}$ \\
\hline
\end{tabular}




\begin{tabular}{|c|c|c|}
\hline Indicator/variable & Source of data & Notes \\
\hline $\begin{array}{l}\text { Distribution of economic } \\
\text { benefits } \\
\text { - Household economy } \\
\text { (household income from SSF), } \\
\text { exports from SSF (quantity } \\
\text { and value), intersectoral } \\
\text { linkages, etc. } \\
\text { - Proportion of income } \\
\text { derived from fishing among } \\
\text { lower-income quintiles } \\
\text { - Spatial distribution of } \\
\text { fisheries value (number of } \\
\text { fishers/km) } \\
\text { - Regional/local economic } \\
\text { stability (rate of change) }\end{array}$ & $\begin{array}{l}\text { - HIES, FAO, World Bank } \\
\text { - Economic multipliers, } \\
\text { indicators of dependency }\end{array}$ & $\begin{array}{l}\text { - How much and who benefits } \\
\text { economically from SSF? } \\
\text { - Analysis by income quintiles, for } \\
\text { equitable distribution of economic } \\
\text { benefits, particularly in poorer } \\
\text { communities } \\
\text { - Spatial distribution to show breadth/ } \\
\text { spread of economic benefits } \\
\text { - Case studies: fisheries stability } \\
\text { contributes to community stability }\end{array}$ \\
\hline $\begin{array}{l}\text { Direct/indirect economic } \\
\text { value } \\
\text { - Full value accounting, in } \\
\text { terms of nutrition, food } \\
\text { security or environmental } \\
\text { services } \\
\text { - Direct and indirect value } \\
\text { added (plus distribution of } \\
\text { value added along the supply } \\
\text { chain and among agents) }\end{array}$ & $\begin{array}{l}\text { - National statistics show } \\
\text { increasing inland fisheries; } \\
\text { direct/indirect economic } \\
\text { values } \\
\text { - World Bank }\end{array}$ & $\begin{array}{l}\text { - Need to show better baselines } \\
\text { - Highly constrained ability to narrate } \\
\text { trends in fisheries } \\
\text { - To show the current value and } \\
\text { contribution of inland fisheries } \\
\text { - Also develop the dialogue of whether } \\
\text { inland fisheries trends are declining or } \\
\text { rising (where and why) } \\
\text { - Underpin economic arguments } \\
\text { - Production to provide data for } \\
\text { valuation } \\
\text { - Inland fisheries are declining or rising } \\
\text { (where and why?) }\end{array}$ \\
\hline \multicolumn{3}{|l|}{ Governance } \\
\hline $\begin{array}{l}\text { Governance participation, } \\
\text { structure, level of } \\
\text { organization and regulatory } \\
\text { aspects } \\
\text { - Illegal fishing } \\
\text { - Tenure/access } \\
\text { - Policy on devolvement } \\
\text { management } \\
\text { - Rights of fishers } \\
\text { - Representation }\end{array}$ & $\begin{array}{l}\text { - WWF } \\
\text { - EDF }\end{array}$ & $\begin{array}{l}\text { - Who gets what, when, how much, } \\
\text { and why related to pre- and post- } \\
\text { harvest activities } \\
\text { - Development trends and how they } \\
\text { affect access to inland fisheries } \\
\text { - The extent to which inland fisheries } \\
\text { are self-employed and to which they } \\
\text { are employees, and the trend towards } \\
\text { rationalization of fisheries into } \\
\text { commercial industrial models } \\
\text { - Areas where fishers govern resources } \\
\text { (e.g. TURFs, LMMAs) and provide } \\
\text { additional management capacity where } \\
\text { needed }\end{array}$ \\
\hline $\begin{array}{l}\text { Financing } \\
\text { - (credit, investment) }\end{array}$ & & $\begin{array}{l}\text { - Are there financial risks in inland } \\
\text { fisheries? Revolving credit systems? } \\
\text { Financial risks? Poorest fishers? } \\
\text { - Low capital, low investment - easy to } \\
\text { enter the fishery }\end{array}$ \\
\hline
\end{tabular}

Additionally, the working group sessions and the plenary discussions produced an initial list of potential measures of threats to the above socio-economic contributions of small-scale fisheries (pending data availability), presented here in Table 5. 
TABLE 5

Threats to socio-economic contributions of small-scale fisheries

\begin{tabular}{|c|c|c|}
\hline $\begin{array}{l}\text { Type of SSF contribution } \\
\text { threatened }\end{array}$ & Indicator/variable & Notes \\
\hline \multirow{3}{*}{ Economic contributions } & Subsidies & UBC Ocean Institute, WTO \\
\hline & Imports & $\begin{array}{l}\text { Imports from unfair trade } \\
\text { (product dumping), especially } \\
\text { poorly timed; potential sources } \\
\text { include WTO, CeDePesca }\end{array}$ \\
\hline & Illegal fishing & $\begin{array}{l}\text { Weak governance and/or lack of } \\
\text { regulation and unequal access }\end{array}$ \\
\hline \multirow{7}{*}{ Multiple contributions } & Fishing pressure & $\begin{array}{l}\text { Weak governance and/or lack of } \\
\text { regulation and unequal access }\end{array}$ \\
\hline & $\begin{array}{l}\text { Distortion of demand and } \\
\text { supply }\end{array}$ & $\begin{array}{l}\text { For example, status of resources } \\
\text { in coastal areas (e.g. Salas et al. } \\
2011 \text {, Coastal Fisheries in Latin } \\
\text { America and the Caribbean) }\end{array}$ \\
\hline & Physical displacement & \\
\hline & Climate change and variability & $\begin{array}{l}\text { For example, through } \\
\text { competing uses for freshwater, } \\
\text { e.g. from hydropower and } \\
\text { agriculture }\end{array}$ \\
\hline & Loss of social capital & $\begin{array}{l}\text { Potential sources: UBC Ocean } \\
\text { Institute }\end{array}$ \\
\hline & & $\begin{array}{l}\text { Migration, marginalization, } \\
\text { but also inequality and power } \\
\text { imbalances leading to loss of } \\
\text { rights, including access }\end{array}$ \\
\hline & & $\begin{array}{l}\text { Land use changes (can lead to } \\
\text { eutrophication) }\end{array}$ \\
\hline
\end{tabular}




\section{CONCLUSIONS AND RECOMMENDATIONS}

\section{CONCLUSIONS}

The session was introduced through a number of slides summarizing findings from the workshop. The discussions identified a number of conclusions on how to conduct the study, which are summarized below:

\section{Objectives of a follow-up study to the $\mathbf{2 0 1 2}$ Hidden Harvest report}

The workshop concluded that a follow-up study to the 2012 Hidden Harvest should be conducted in order to continue to advocate for SSF and ensure that they receive the appropriate attention from policy-makers. The study would have two objectives:

1. to illuminate the hidden contributions of small-scale fisheries to the three dimensions of sustainable development - social, economic and environmental - as well as governance, quantifying these contributions to every extent possible and (where possible) estimating both the current and potential contributions; and

2. to identify the key threats to these contributions (both external and internal), and/ or opportunities to enhance them, creating a narrative including key variables that can be quantified.

The discussion of conclusions noted that the aim of the study would be to help correct the institutional bias against small-scale fisheries, showing the potential benefits from government support and policy reform where needed.

\section{Scope}

The workshop concluded that the scope of the follow-up study would be limited to SSF, but would encompass both developed and developing countries - with a breakdown of the two permitting analysis of contributions to poverty reduction and global objectives for developing countries (as well as a distinction for indigenous peoples). While the focus would be SSF, the study would include an updated Thomson Table as appeared in the 2012 Hidden Harvest report, ${ }^{26}$ comparing a set of measures of contributions from small-scale fisheries and large-scale fisheries. The workshop agreed that the study on small-scale fisheries would include both inland and marine small-scale fisheries with disaggregation between the two, and also that it would aim to highlight comparisons of small-scale fisheries' contributions to those of other sectors.

26 The Thomson Table shows a comparison between small- and large-scale fisheries. The original table was published in the ICLARM Newsletter in July 1980 in an article by David Thomson on conflict within the fishing industry, arguing for the need to protect inshore fishing grounds and support small-scale fishers (Thomson, 1980). 


\section{Target audience}

The workshop agreed that, following the objectives, the target audience for the study would be two-fold: (i) policy-and decision-makers both in fisheries and beyond, and at national and decentralized levels, in order to increase attention and appropriate support for small-scale fisheries; and (ii) small-scale fisheries advocates such as civil society organizations and other fisherfolk organizations, researchers, Non-governmental Organizations, etc.

\section{Communication}

Following on lessons learned from the 2012 Hidden Harvest report, the workshop stressed the importance of early and frequent communication in order to ensure that the study objectives are achieved, including beyond the fisheries sector (notably in the global food policy dialogue). The workshop recommended that the status and objectives of the study be reported to the FAO Committee on Fisheries (COFI) meeting in 2018, as well as to a number of other relevant international events such as the Our Ocean Conference, the 2018 World SSF Congress, the World Food Prize, and the Global Food Security Conference. To support these efforts, the workshop recommended the preparation of communication materials (flyers, postcards, etc.) that can easily convey the objectives and next steps to the target audience and potential partners, informing the latter as to how they might contribute (and who to contact). In particular, the workshop recommended communicating with SSF communities and representative CSOs during and after the study, for example by providing key facts, bullet points, etc. that might better equip these communities to be their own advocates. The workshop also noted the potential of academic audiences to use the study to drive future research and help fill knowledge gaps on SSF (e.g. filling out the wish list), suggesting that communications to this group for motivating research might be different from others (highlighting usable data and robust methodologies, helping to plan publications, etc.). Additionally, to increase buy-in for the study, the workshop recommended communication to identify additional partners.

Finally, the workshop recommended establishing an online web presence for the study, including discussion groups, to ensure that the process is inclusive and that potential stakeholders are well-informed on the objectives of the study and status of work. This could include information as to how researchers can become involved, and could be linked to the Too Big To Ignore (TBTI) network.

\section{Recommendations for the main content of the study}

The workshop agreed on the following areas for the key content or broad outline of the study, including:

1. Context

a. Definition of small-scale fisheries as a continuum, potentially based on an index of descriptive variables

b. Review of major findings on small-scale fisheries since the 2012 Hidden Harvest report

c. Global policy context, in terms of the Sustainable Development Goals (also note that SSF analysis has not been linked to the informal sector, and there may be lessons that can be learned from economic dialogues on informality)

d. Opportunities, notably the adoption of the SSF Guidelines and the momentum they have generated 
2. Contributions of SSF

a. Facts, including comparisons, regarding the current and potential net contributions of small-scale fisheries in the social, economic, environmental and governance spheres

3. Threats to these contributions

a. As a narrative, with quantitative information

4. Recommendations for appropriate attention and support

a. Recommendations for appropriate attention and in some cases support in order to respond to the threats, in terms of policy, action and practice

b. Strong, "must do" recommendations that aim to incorporate small-scale fisheries into the global food policy dialogue (e.g. the World Food Prize)

5. Recommendations for future research

a. Recommendations for future research, via identification of the types of variables that would ideally be measured in order to better describe the contributions of small-scale fisheries (e.g. filling in some of the gaps in the wish list)

\section{Sources of information}

Given that the study would not include primary data collection due to time and resource constraints, the workshop agreed that a number of global data sets are available for use that did not exist when the 2012 Hidden Harvest report was prepared, both within and outside the fisheries sector. These include the FAO INFOODs database, the western Pacific household income and expenditure survey (HIES), and the indigenous peoples database built at the University of British Columbia. These databases would be utilized for the new study, along with academic and grey literature as well as national statistics. In addition, as with the 2012 Hidden Harvest report, national case studies would form a key source of information for many of the SSF contributions measured.

\section{Methods}

The workshop recommended a mixed-methods approach, essentially pulling together a variety of data sources into a coherent and clear picture of the global socio-economic contributions of SSF, rather than primary data collection. This would include designing the conceptual framework for the variables to be measured from existing data sources and the various methods to be used; being somewhat opportunistic and mapping ongoing or planned studies against the variables to evaluate where data collection may already be possible; and then developing criteria for selection of case studies that capture a wide spread of various types of small-scale fisheries along the continuum. Case studies would provide information that could be extrapolated to global estimates, and/or illustrate global findings and data sets. For the latter, case studies may illustrate bright spots where small-scale fisheries contributions are robust and threats are low, or situations where support may be needed.

\section{RECOMMENDATIONS}

The workshop concluded with discussion on the next steps to design and launch the study over the next two years, including:

- Design of the study - including a conceptual framework illustrating the variables to be estimated and their linkages (with additional scoping to determine available data based on discussion and recommendations in the workshop), and the methods used for estimation - to be completed by the end 
of 2017. FAO/Duke University will take the lead for the study design, and likewise WorldFish with regard to a paper on methods.

- Resource mobilization for the full study would be an ongoing process.

- Building upon the workshop, partnerships for conducting the study would be mobilized collaboratively and on a rolling basis.

- Flyers and other communication materials on the study objectives, key facts from the 2012 Hidden Harvest report, and next steps and ways to participate would be prepared and circulated to workshop participants by FAO as a first step in ongoing communication during the course of the study. Opportunities to communicate about the study will be taken as and when feasible and opportune, for example at the 2017 session of the Committee on World Food Security (CFS), the 2018 session of COFI, and possibly in The State of World Fisheries and Aquaculture (SOFIA) report, as well as at the 2018 Our Ocean Conference and also the $3^{\text {rd }}$ World SSF Congress in 2018 (among others).

- When study design is completed, case studies would be prepared together throughout 2018 with analysis of global data sets.

- Results would be compiled and analysed, with the study finalized in the first half of 2019.

Throughout this process, interim products may be published as input to the study, together with ongoing communications, in order to maintain momentum.

\section{Engagement}

The workshop agreed that there may be opportunities to "crowdsource" contributions throughout the process of conducting the study, from the participants as well as others. Opportunities for discrete papers published in the scientific literature as milestones along the process could be sought, and calls for participation linked to the web presence discussed under communications above. 


\section{Annex 1 - List of participants}

\author{
Michael AKESTER \\ Country Director \\ WorldFish \\ MYANMAR \\ E-mail:m.akester@cgiar.org

\section{Ricardo AMOROSO} \\ University of Washington \\ UNITED STATES OF AMERICA \\ E-mail: ricardoamoroso@yahoo.com
}

\section{Mary Barby BADAYOS-JOVER}

Director

Gender and Development Program

University of the Philippines

THE PHILIPPINES

E-mail: mpbadayosjover@up.edu.ph

\section{David BUNNELL}

Research Fishery Biologist/Studies inland fisheries in Great Lakes and across the globe by using remote sensing

Great Lake Science Center (USGS)

UNITED STATES OF AMERICA

E-mail: dbunnell@usgs.gov

\section{Anthony CHARLES}

Professor and Senior Research Fellow

Saint Mary's University and

Community Conservation Research

Network (CCRN)

CANADA

E-mail: Tony.Charles@smu.ca

\section{Ratana CHUENPAGDEE}

Director/Professor

TBTI/Memorial University

CANADA

E-mail: ratanac@mun.ca

\section{Ian COWX}

Director and Professor

Hull International Fisheries Institute,

University of Hull

UNITED KINGDOM

E-mail: I.G.Cowx@hull.ac.uk

\section{Steve CUNNINGHAM}

GFCM

E-mail: cunningham@iddra.org

Jessica GEPHART

Postdoctoral Fellow

SESYNC University of Maryland

UNITED STATES OF AMERICA

E-mail: jgephart@sesync.org

\section{David GILL}

George Mason University/

Conservation International UNITED STATES OF AMERICA

E-mail: gill.david.a@gmail.com

\section{Amber HIMES-CORNELL}

Social scientist researcher

Université de Bretagne Occidentale

FRANCE

E-mail: amberhimescornell@gmail.com

\section{Jeppe KOLDING}

Professor

University of Bergen

NORWAY

E-mail: jeppe.kolding@bio.uib.no

\section{Patrick MCCONNEY}

Senior Lecturer (Marine Resource

Management Planning)

Centre for Resource Management and

Environmental Studies (CERMES)

The University of the West Indies

BARBADOS

E-mail: patrick.mcconney@gmail.com

Essam Yassin MOHAMMED

International Institute for Environment and Development (IIED)

UNITED KINGDOM

E-mail: eymohammed@iied.org 
Mustapha OUMAROUS

Fishery engineer

National Institute of Fisheries Research

(Institut National de Recherche

Halieutique)

MOROCCO

E-mail: oumarous@hotmail.com/

oumarous@inrh.ma

\section{AnaMaria PARMA}

Principal Researcher

Centro para el Estudio de Sistemas

Marinos; Centro Nacional Patagónico-

CONICET

ARGENTINA

E-mail:parma@cenpat-conicet.gob.ar

\section{Silvia SALAS}

Professor

Center for Research and Advanced

Studies of the National Polytechnic

Institute

MEXICO

E-mail: ssalas@cinvestav.mx

\section{Michael SHARP}

Economic Advisor (Household

Surveys)

Pacific Community (SPC)

PACIFIC REGION

E-mail: michaels@spc.int

Rashid SUMAILA

Professor

Institute for the Oceans

University of British Columbia

(UBC)

CANADA

E-mail: r.sumaila@fisheries.ubc.ca

Lydia Chi Ling TEH

Research Associate

Nereus Program, UBC

CANADA

E-mail: lydia.teh@oceans.ubc.ca

\section{Yuttana THEPAROONRAT}

Training and Research Supporting

Division Head

SEAFDEC/Training Department

THAILAND

E-mail: yuttana@seafdec.org

\section{Magnus TORELL}

Senior Advisor

Southeast Asian Fisheries Development

Centre (SEAFDEC)

THAILAND

E-mail: magnus@seafdec.org

Paul VAN ZWIETEN

Wageningen University

THE NETHERLANDS

E-mail: paul.vanzwieten@wur.nl

\section{Xavier VINCENT}

Lead Fisheries Specialist

Environment \& Natural Resources

World Bank Group

UNITED STATES OF AMERICA

E-mail:xvincent@worldbank.org 


\section{Resource team}

Xavier BASURTO

Associate Professor

Duke University

UNITED STATES OF AMERICA

E-mail: xavier.basurto@duke.edu

Yumiko KURA

Country Director

WorldFish

CAMBODIA

E-mail:Y.Kura@cgiar.org
David MILLS

WorldFish

AUSTRALIA

E-mail: D.Mills@CGIAR.ORG

John VIRDIN

Director, Ocean and Coastal Policy

Program, Nicholas Institute

Duke University

UNITED STATES OF AMERICA

E-mail: john.virdin@duke.edu

\section{Yvette DIEI OUADI}

Fishery Officer

E-mail: Yvette.DieiOuadi@fao.org

Nicole FRANZ

Fishery Planning Analyst

E-mail: Nicole.Franz@fao.org

\section{Simon FUNGE-SMITH}

Senior Fisheries Resources Officer

E-mail: Simon.FungeSmith@fao.org

Jennifer GEE

Fishery Officer

E-mail: Jennifer.Gee@fao.org
Felix MARTTIN

Fishery Resources Officer

E-mail: Felix.Marttin@fao.org

Florence POULAIN

Fisheries and Aquaculture Officer

E-mail: Florence.Poulain@fao.org

\section{Susana SIAR}

Fishery Industry Officer

E-mail: Susana.Siar@fao.org

\section{Lena WESTLUND}

FAO Consultant

E-mail: lena.westlund@fao.org 


\section{Annex 2 - Workshop agenda}

Day 1: 27 June 2017

Opening statement

Árni Mathiesen, Assistant Director-General of the FAO Fisheries and Aquaculture Department

Self-introduction by participants

Overview of workshop objectives, expected outputs and modus operandi

Nicole Franz, FAO

Reflection and recap on the 2012 Hidden Harvest process and outcomes: strengths, weaknesses and lessons learned

David Mills, WorldFish and Lena Westlund, FAO

Presentation of background paper

John Virdin/Xavier Basurto, Duke University

Coffee/tea break

Plenary discussion

What do we mean by small-scale fisheries?

Lena Westlund and Simon Funge-Smith, FAO, and Ratana Chuenpagdee, Too Big To Ignore

Discussion on SSF characteristics and how to deal with it in the new study

Lunch

Key areas for which data and information are needed

- Updating the FAO assessment of the status of inland fisheries

Simon Funge-Smith, FAO

- Assessing coastal fisheries

Nicolas Gutierrez, FAO

- Frameworks for assessing local-level conservation and stewardship in small-scale fisheries

Tony Charles, St. Mary's University, Canada

Discussion

Introduction to Working group - Session 1: What do we want to know about small-scale fisheries and why?

Coffee/tea break

Working groups - Session 1

Closure of the day

Dinner (at self cost, restaurant TBD) 
Day 2: 28 June 2017

Summary of previous day

Presentation of Working group Session 1 results in plenary and discussion

Data/information, sources and methodologies that can be useful for the new study

- FAO global statistics, data frameworks and ongoing experience with data collection for improving data of small-scale fisheries

Jennifer Gee/Mark Dimech, FAO

- Revealing the socio-economic features of small-scale fisheries in southeast Asia Yuttana Theparoonrat, Southeast Asian Fisheries Development Centre (SEAFDEC)

- Data collection methods for small-scale fisheries landing

Jeppe Kolding, University of Bergen

Coffee/tea break

Data/information, sources and methodologies that can be useful for the new study

- Subsidies: small versus large-scale fisheries subsidies

Rashid Sumaila, University of British Columbia

- Indigenous coastal communities

Lydia Teh, Nereus Program

- Constructing consumption aggregates for food security analysis using household income and expenditure surveys from the Pacific Island Countries and Territories

Michael Sharp, Pacific Community (SPC)

- A bite into the nutritional value of fish

Christina Hicks, Lancaster University - presented by David Mills, WorldFish

Introduction to Working group - Session 2: Where or how can we find the data, and what methodologies should we use for data collection and analysis/extrapolation?

Lunch

Working groups - Session 2

Coffee/tea break

Continuation of Working group Session 2

Shared session with "Climate change implications for fisheries and aquaculture: Overview of current knowledge and responses" meeting

Closure of the day

Day 3: 29 June 2017

Small-scale fisheries in Morocco

Mustapha Oumarous, Institut National de Recherche Halieutique (INRH)

Presentation of Working group Session 2 results in plenary and discussion

Working groups - Session 3: Suggested next steps and potential partnerships

Coffee/tea break

Continuation of Working group Session 3

Presentation of Working group Session 3 results in plenary and discussion

Lunch

Summing-up presentation: draft conclusions and recommendations from the workshop

Discussion and agreement on conclusions and recommendations

Coffee/tea break

Discussion and agreement on next steps (what, when and by whom)

Closure of the workshop 


\title{
Annex 3 - Opening statement
}

\author{
Opening address by Árni Matbiesen, ADG Fisheries and Aquaculture \\ Department, FAO \\ Ladies and Gentlemen, Good Morning!
}

I would like to welcome all of you to Rome and to thank you for having kindly accepted to provide your expertise to this "Workshop on improving our knowledge on small-scale fisheries: data needs and methodologies".

As you are aware, small-scale fisheries play an important role in contributing to food security, nutrition, livelihoods, and local and national economies. However, there is limited data and information available on this contribution and hence smallscale fisheries tend to be overlooked and marginalized in policy processes, leading to low levels of investment in the sector. This workshop constitutes an important step towards improving our knowledge on small-scale fisheries and communicating this information, something I believe you all have an interest in doing, and I see this as a great collaborative effort.

The Hidden Harvest report, published in 2012, was achieved through collaboration by the World Bank, FAO and WorldFish as well as by those involved in the many case studies that underpinned the study. The 2012 Hidden Harvest was a review of the economic importance of fisheries, focusing in particular on employment, catches and GDP, and distinguishing between small- and large-scale fisheries, and marine and inland fisheries. In addition, it also included a separate analysis of recreational fisheries.

The Hidden Harvest report has until now remained the only source of quantitative information on small-scale fisheries at an aggregate level, and its estimates and information are still valid. Nevertheless, it would benefit from being refined and updated with new data and also from including additional dimensions of the contribution of small-scale fisheries to food security and nutrition, poverty reduction, and the three pillars of sustainable development more broadly.

Moreover, since the Hidden Harvest was published, new relevant policy frameworks have become available: first, the Voluntary Guidelines for Securing Sustainable SmallScale Fisheries in the Context of Food Security and Poverty Eradication (the SSF Guidelines). The SSF Guidelines were adopted by the FAO Committee on Fisheries (COFI) in 2014 and represent a consensus on how to move small-scale fisheries into sustainability through a holistic and integrated approach based on human rights.

Second are the Sustainable Development Goals (SDGs). Small-scale fisheries make important contributions to many of the 17 SDGs adopted by the United Nations General Assembly (UNGA) in 2015, in particular to SDG 14 on the sustainable use of our oceans, but also several other targets including under SDG 1 (No poverty), SDG 2 (Zero hunger) and SDG 5 (Gender equality), to name but a few.

And there are many more global agreements and targets, to the achievement of which small-scale fisheries can make a contribution.

To allow for the application of the SSF Guidelines principles and provisions and to understand and promote the contribution of small-scale fisheries to the various targets, including the SDGs, better information and accuracy on small-scale fisheries activities and their environmental and socio-economic dimensions are needed.

This is why we, FAO together with WorldFish, are now initiating this work on improving small-scale fisheries data and knowledge. We hope that by providing a 
fuller and more accurate picture of the sector, it will receive more support from policyand decision-makers than what has been the case until now. I believe that we have a common interest in such support and hope that you will join us in the efforts to ensure that small-scale fishers, fishworkers and their communities receive the attention they deserve. We need broad collaboration to achieve this from all different stakeholder groups, including governments, regional and international organizations, small-scale fisheries organizations and civil society, academia, and NGOs.

We see this workshop as a very important stepping stone and expect that, at the end of the three days, we will have a clear view of the scope and contents of the new Hidden Harvest study and what methodologies to use.

But we will also need strong partnerships because the work really starts after the workshop and we, FAO and WorldFish, cannot - and should not - do this on our own. Hence, I count on your support not only for the workshop but also in what follows. I also hope others who were not able to be in Rome for this workshop will join in the efforts.

I would like to take this opportunity to thank existing partners, including Norway for its support to the implementation of the SSF Guidelines, as well as for this workshop.

Let me close these opening remarks by wishing you all a fruitful workshop that will help put the contribution of small-scale fisheries on the map for the benefit of smallscale fishing communities themselves, as well all those who depend on the fish and value created by these communities for their livelihoods and well-being. 


\section{Annex 4 - Working group distribution}

\begin{tabular}{|l|l|l|}
\hline \multicolumn{1}{|c|}{$\begin{array}{c}\text { 1 MARINE CAPTURE } \\
\text { IRAQ ROOM }\end{array}$} & \multicolumn{1}{|c|}{$\begin{array}{c}\text { 2 INLAND FISHERIES } \\
\text { INDIA ROOM A 327/9 }\end{array}$} & \multicolumn{1}{c|}{$\begin{array}{c}\text { 3 PRE- AND POST-HARVEST } \\
\text { IRAQ ROOM }\end{array}$} \\
\hline $\begin{array}{l}\text { Paul van Zwieten } \\
\text { Tony Charles }\end{array}$ & Jeppe Kolding \\
Michael Sharp & lan Cowx & Barby Badayos-Jover \\
David Gill & Mike Akester & Silvia Salas \\
Ricardo Amoroso & Bo Bunnel & Jessica Gebhart \\
Mustapha Oumarous & Yumiko Kura & Lydia Teh \\
Ana Parma & Felix Marttin/ & Patrick McConney \\
Steve Cunningham & Simon Funge-Smith & Nico Gutierrez \\
Amber Himes-Cornell & T. Yuttana & Rashid Sumaila \\
\hline
\end{tabular}




\title{
Annex 5 - Background paper
}

\author{
BACKGROUND PAPER \\ "Hidden Harvest 2": \\ Global measures of small-scale \\ fisheries
}

Prepared by John Virdin and Xavier Basurto, Duke University

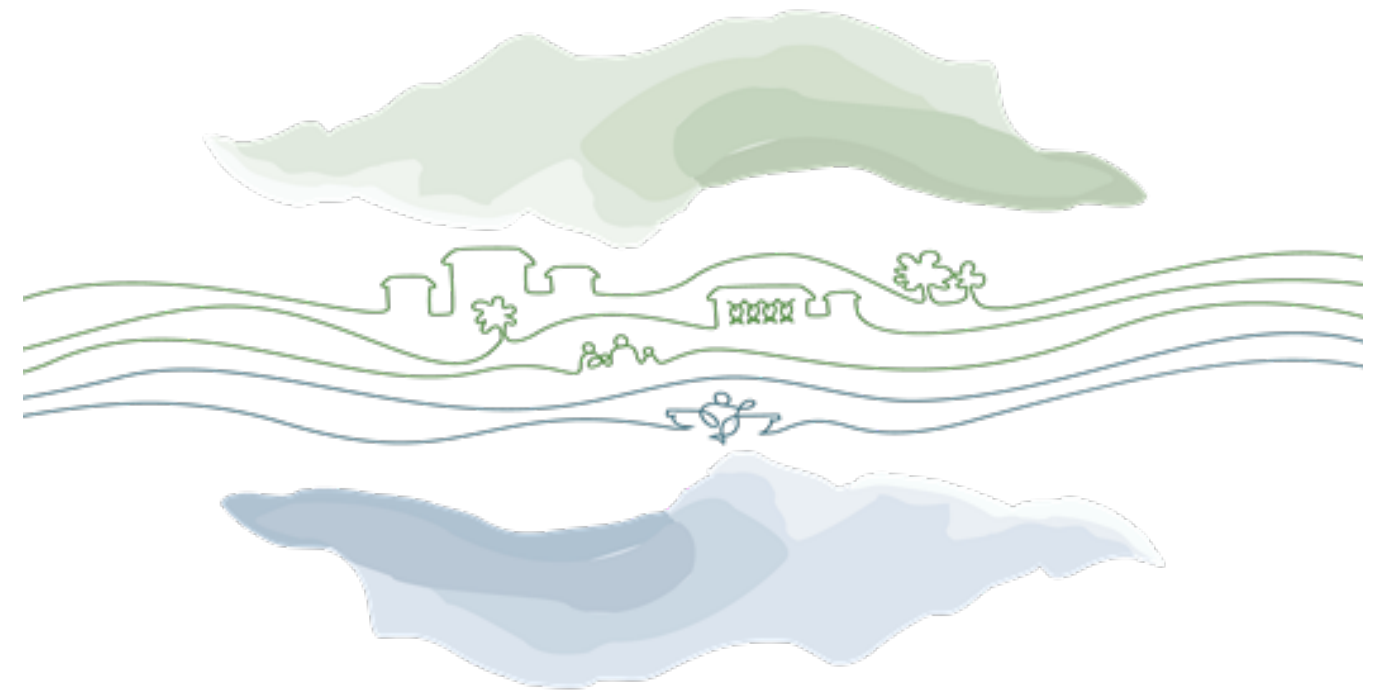

Workshop on improving our knowledge on small-scale fisheries: data needs and methodologies

27-29 June 2017

FAO, Rome 


\section{CONTENTS}

I. Introduction: What do we want to know about small-scale fisheries and why?

60

II. Objective and methodology of this background paper 65

III. Results: Inventory of available data 68

IV. Results: Proposed available indicators and data collection methods $\quad 73$

V. Discussion: Proposed approach and case studies 83

$\begin{array}{ll}\text { References } & 87\end{array}$

Appendix 1. Summary of measures estimated in Hidden Harvest 90

Appendix 2. Synthesis of measures submitted to TBTI's ISSF since $2010 \quad 91$

Appendix 3. Full list of indicators searched in the scientific literature 93

Appendix 4. Synthesis of measures recorded in scientific literature since 201198 


\section{ABBREVIATIONS AND ACRONYMS}

ABNJ

AIDS

AU IBAR

BNF

CIPA

COFI

CONMECOOP

CPUE

CRODT

CSRP

EEZ

FAO

FAOSTAT

FBS

FCWC

GDP

GFCM

GPS

HDR

$\mathrm{HH} 1$

HIV

HLPE

ICSF

IMARPE

IMAS

IMBO

IMROP

INDP

ISSF

ITQ

MPA

ODA

OECD

SAUP

SDG

SEAFDEC

SPC

SSF

STD

TBTI

TNC

TURF

UN

UNVI

WCA
Areas Beyond National Jurisdiction

Acquired Immunodeficiency Syndrome

African Union InterAfrican Bureau for Animal Resources

Bureau for National Fisheries in Liberia

Center for Industrial and Artisanal Fisheries in Guinea-Bissau

Committee on Fisheries

Mexican Confederation of fisheries and aquaculture cooperatives

Catch per unit effort

Center for Oceanographic Research Dakar-Thiaroye in Senegal

Sub-Regional Fisheries Commission in West Africa

Exclusive Economic Zone

Food and Agriculture Organization of the United Nations

Food and Agriculture Organization Statistics Division

Food Balance Sheet

Fishery Committee of the West Central Gulf of Guinea

Gross domestic product

General Fisheries Commission for the Mediterranean

Global positioning satellite

Human Development Report

2012 Hidden Harvest

Human immunodeficiency virus

High Level Panel of Experts

International Collective in Support of Fishworkers

Institute of the Ocean in Peru

Institute for Marine and Antarctic Studies at the University of Tasmania

Institute for Marine Biology and Oceanography in Sierra Leone

Mauritania Institute for Oceanographic and Fisheries Research

National Institute for Fisheries Development in Cabo Verde

Information System on Small-Scale Fisheries

Individual transferable quota

Marine protected area

Official development assistance

Organisation for Economic Co-operation and Development

Sea Around Us Project at the University of British Columbia

Sustainable Development Goal

Southeast Asian Fisheries Development Centre

Pacific Community

Small-scale fisheries

Sexually transmitted disease

Too Big To Ignore

The Nature Conservancy

Territorial use rights for fishing

United Nations

United States Virgin Islands

World Program for the Census of Agriculture 
Workshop Session 1: What do we want to know about small-scale fisheries and why?

The following section of this paper, entitled "Introduction," corresponds to the first session of the workshop.

\section{Introduction: What do we want to know about small-scale fisheries and why?}

\section{The estimated socio-economic contributions of global small-scale fisheries}

Fisheries described as "small-scale" contribute significantly to food security, nutrition, livelihoods and local and national economies throughout the world (FAO, 2016a). Such small-scale fisheries (SSF) have been estimated to account for over 50 percent of animal protein intake in many of the least developed countries of Africa and Asia, with potentially one billion people in southeast Asia relying predominantly on fish for animal protein (FAO 2008-2016). These fisheries have also been identified as helping to prevent poverty in many regions, functioning as a "bank in the water" that provides savings and a safety net for periods of vulnerability (Béné, 2006). Although perhaps even more difficult to measure, these fisheries often have strong cultural importance, and many social scientists who study SSF note that fishing is also a particular "way of living", where fishing communities are characterized by a very distinct and very strong sense of cultural identity and social bonds (Mills et al., 2011).

The challenge of measuring the socio-economic contributions of small-scale fisheries Despite the reported importance of SSF to so many populations worldwide, there is relatively little reliable and accessible information available on their socio-economic contributions, and hence SSF have been historically ignored in both national and international policy dialogues (de Graaf et al., 2011). In particular, SSF are masked in the global fisheries production statistics, which are based on aggregated catch statistics reported by governments to FAO (de Graaf et al., 2011). These hidden or unrecognized socio-economic contributions of SSF around the world - often to some of the poorest and most vulnerable populations - reinforce perceptions of their lack of value and significance in national economies. As a result, a number of efforts to increase measures of SSF have been undertaken, with the theory that better information on the size and socio-economic importance of these fisheries could enhance the political voice of fishers and fishing communities, and better inform policy-makers about the roles they play (FAO, WorldFish and World Bank, 2008).

\section{The 2012 Hidden Harvest study attempted to address this challenge}

First conceived at a FAO/WorldFish Center workshop on interdisciplinary approaches to assessment of SSF in Rome in 2005, the two organizations launched a "Big Numbers Project" that produced a preliminary report trying to measure the size of SSF activity worldwide (FAO, WorldFish and World Bank, 2008). This report focused largely on updating the 1980 Thomson table and particularly household-level information on food security, using a case study approach to disaggregate FAO data, where catch rates per fisher were estimated and multiplied by estimates of fishers (including comparing case study estimates to official reports to get a ratio of under-reporting (FAO, WorldFish and World Bank, 2008). Preliminary results suggested that, among others, the catch 
from inland fisheries was heavily under-reported, with a large percentage likely consumed locally within the community (FAO, WorldFish and World Bank, 2008).

Building upon the early work of the Big Numbers Project, in 2012 the World Bank, FAO and the WorldFish Center published the Hidden Harvest: the Global Contribution of Capture Fisheries, as the only global reference for quantitative information that disaggregated large-scale from SSF and their likely production and employment. The objective of this report was to collate and synthesize data from developing countries highlighting the relative importance of SSF in comparison with large-scale fisheries, identifying critical data gaps and possible solutions for these, and providing insights into the design of a platform for future data collection (Mills et al., 2011). While not directly replicating the outputs of the Thomson Table, the report updated many of the indicators in a snapshot in time (generally from 2004 to 2007), and further disaggregated marine and inland fisheries (Mills et al., 2011). The methodology for the Hidden Harvest report relied on extrapolating from case studies, focusing on the economic importance of fisheries and particularly employment, catches and GDP, distinguishing between small- and large-scale in each case. However, the report did have limitations, as it did not include a number of measures such as contribution of nutrition, ecosystem services, and other less tangible goods delivered by SSF. A summary of the measures estimated in Hidden Harvest is provided in Appendix 1.

There is a need to update and expand the Hidden Harvest study with more information on SSF, to support evidence-based policies to assist these fisheries to achieve their potential contributions to sustainable development, particularly given the global agreement in 2015 on Sustainable Development Goals (SDGs).

While Hidden Harvest provided a first effort to measure small-scale fishing activity globally, it provided only a limited picture and would benefit from being refined and updated to include additional aspects of the contribution of SSF to food security and nutrition, poverty reduction, and the three dimensions of sustainable development more broadly. Indeed the contributions of SSF are still generally considered to be underestimated, if not overlooked. Additionally, since 2012, the need for accurate and comprehensive measures of the socio-economic contributions of SSF has only grown, as the United Nations General Assembly adopted a set of 17 Sustainable Development Goals (SDGs) with targets to be achieved by 2030, the first two of which aim to end poverty and hunger respectively (United Nations General Assembly, 2015). ${ }^{27}$ Given the level of employment and food provided by SSF in developing countries, better measures of SSF activity and targeted policies are expected to be integral to achieving these SDGs, not just in terms of production but also broader socio-economic dimensions and particularly contributions to food security (Gee, 2015). Additionally, in 2014 the Voluntary Guidelines for Securing Sustainable Small-Scale Fisheries in the Context of Food Security and Poverty Eradication were adopted as the only international policy instrument specifically designed for SSF (Basurto et al., 2017). The SSF Guidelines promote an approach to SSF governance focused on the principle of respect for human rights, and particularly poverty eradication and food security (FAO, 2015). The application of the SSF Guidelines to fisheries governance systems will also require greater information and accuracy on SSF activity and socio-economic contributions,

27 SDG 1 includes targets based on measures of poverty using income (USD 1.25/day), and explicitly aiming to reduce people living in poverty while increasing the resilience of the poor and the social protection systems available to them. SDG 2 includes targets aiming to expand access to safe, nutritious and sufficient food all year round, and to end all forms of malnutrition, including targets on stunting and wasting of children under 5. See https://sustainabledevelopment.un.org/. 
particularly since a monitoring system for application of the SSF Guidelines based on a set of indicators is envisaged.

The objective of a Hidden Harvest 2 report would be to increase the knowledge base on the global socio-economic contributions of SSF, with a focus on their role in ending poverty (SDG1) and bunger (SDG2) and sustainable development more broadly.

While the first Hidden Harvest focused on disaggregating global fishing statistics to show the split between small- and large-scale fishing, Hidden Harvest 2 would focus on expanding the global knowledge base on SSF, given their prevalence in developing countries. Additionally, within SSF the study would aim to the extent possible to better measure the level of subsistence fishing worldwide, perhaps the most hidden of fishing harvests.

Essentially, Hidden Harvest 2 would aim to build upon the first study to capture a more detailed picture or snapshot of SSF and their role in the different dimensions of sustainable development, increasing the number of variables measured and countries covered, in order to provide a comprehensive and authoritative baseline that will draw the attention of policy- and decision-makers to the importance of SSF and support the tracking of progress. Or in different terms, Hidden Harvest 2 would make the case for greater public and private investment in SSF in the context of food security and poverty eradication, based on the SSF Guidelines. This would include increased public investment allocated through governments' domestic budgets as well as increased aid.

The hypothesis upon which this objective rests is that more data has been collected by governments, scientists and researchers, etc. since the first Hidden Harvest study, so that analyses can be refined and updated to include additional dimensions of the contributions of SSF to poverty reduction, food security and nutrition, among others. This data and analysis would allow for a clearer picture of the socio-economic contributions of SSF and their environmental impacts, as well as the challenges that they are facing and the potential results from increased investment. Additionally, such data and analysis would help inform international policy dialogues.

The audience for this report would be policy-and decision-makers, notably those involved in broader social, environmental and economic policy-making.

Even given the dearth of global measurements, SSF have frequently been described by scientists as facing significant social or shared problems, requiring collective action solutions and in many cases policy responses from the state (Basurto et al., 2017). As mentioned previously, lack of measures and information on SSF and their socioeconomic contributions has hindered such responses in the past, and this report aims to call policy-makers' attention to the roles and needs of SSF - particularly in the context of states' efforts to support achievement of national development objectives, also in the context of the SDGs and other internationally agreed targets. A secondary audience would include the civil society organizations, donors, Non-governmental Organizations, research institutes and agencies supporting SSF and/or other sectors related to fishing communities.

\section{What types of information about SSF would best inform this audience?}

As a starting point, the following table of variables/indicators (the latter defined throughout this paper as variables or concepts) is proposed for discussion, developed from consultations with experts on those variables or indicators with the potential to better measure the contributions of SSF to sustainable development (e.g. to SDGs 1 and 2 among the other SDGs related to SSF), as well as measure the alignment of 
governance with the SSF Guidelines. These variables/indicators are consistent with the core data suggested in the Guidelines to Enhance Fisheries and Aquaculture Statistics through a Census Framework and in the FAO handbook for socio-economic surveys of fishers (Pinello, Gee and Dimech, 2017). The variables/indicators include measures of poverty alleviation in terms of both poverty reduction (i.e. wealth creation) and poverty prevention (i.e. safety net).

TABLE 1. PROPOSED "WISH LIST" OF MEASURES OF SSF

\begin{tabular}{|c|c|}
\hline Variable/indicator & Description \\
\hline \multicolumn{2}{|l|}{ Production and utilization } \\
\hline SSF catch by EEZ & $\begin{array}{l}\text { Harvest in a country's EEZ by SSF, as defined in national legislation (included } \\
\text { in the first Hidden Harvest report) }\end{array}$ \\
\hline SSF catch landed value & $\begin{array}{l}\text { SSF harvest multiplied by the estimated ex-vessel price for species group and } \\
\text { market (included in the first Hidden Harvest report) }\end{array}$ \\
\hline Use & $\begin{array}{l}\text { End use of catch; for human consumption vs non-consumptive uses (reduced } \\
\text { to meals/oil, aquarium trade) (included in the first Hidden Harvest report) }\end{array}$ \\
\hline \multicolumn{2}{|c|}{ Employment (full-time and part-time) } \\
\hline SS fishers (\#) & $\begin{array}{l}\text { Total number of SS fishers engaged in harvesting activities (included in the } \\
\text { first Hidden Harvest report) }\end{array}$ \\
\hline $\begin{array}{l}\text { SSF post-harvest jobs } \\
(\#)\end{array}$ & $\begin{array}{l}\text { Total number of persons engaged full-time or part-time in post-harvest jobs } \\
\text { related to SSF (included in the first Hidden Harvest report) }\end{array}$ \\
\hline Total workforce (\#) & SS fishers + SSF post-harvest jobs (included in the first Hidden Harvest report) \\
\hline $\begin{array}{l}\text { Women as a \% of total } \\
\text { workforce }\end{array}$ & $\begin{array}{l}\text { Total number of women employed in SSF harvesting and post-harvesting jobs, } \\
\text { divided by the total workforce (included in the first Hidden Harvest report) }\end{array}$ \\
\hline $\begin{array}{l}\text { Indigenous or ethnic } \\
\text { workforce }\end{array}$ & $\begin{array}{l}\text { Indigenous persons or ethnic minorities represented in the fishing workforce, } \\
\text { by age group if possible (\%) }\end{array}$ \\
\hline Dependents & Fisher household dependents \\
\hline Disadvantaged & $\begin{array}{l}\text { Employment of disadvantaged segments of the population (elderly, widowed, } \\
\text { orphaned, disabled) }\end{array}$ \\
\hline Labour exploitation & $\begin{array}{l}\text { "Labour exploitation" (average hours worked compared to the legal } \\
\text { maximum) }\end{array}$ \\
\hline \multicolumn{2}{|l|}{ Efficiency } \\
\hline $\begin{array}{l}\text { Catch per SS fisher } \\
\text { (tons) }\end{array}$ & $\begin{array}{l}\text { SSF harvest divided by the estimated number of SS fishers (included in the } \\
\text { first Hidden Harvest report) }\end{array}$ \\
\hline CPUE & Catch per unit effort \\
\hline Discards & $\begin{array}{l}\text { Measuring discards in a fishery: discards of undesirable species, or regulatory } \\
\text { discards (required to discard based on size, species, etc.); estimated volume of } \\
\text { fish caught and discarded at sea by SSF, divided by the total SSF catch }\end{array}$ \\
\hline $\begin{array}{l}\text { SSF catch per ton of } \\
\text { fuel }\end{array}$ & $\begin{array}{l}\text { SSF harvest divided by estimated fuel consumption of harvesting activities } \\
\text { (included in the first Hidden Harvest report) }\end{array}$ \\
\hline Food waste & $\begin{array}{l}\text { Food waste (food loss) that occurs on land - could occur in the market, } \\
\text { processing, end user, etc. }\end{array}$ \\
\hline Subsidy & Subsidizing fishing or subsidies to not fish \\
\hline \multicolumn{2}{|l|}{ Economic contribution } \\
\hline Household economy & Economic contribution to household economy (\% related to other incomes) \\
\hline \multicolumn{2}{|c|}{ Food security and nutrition } \\
\hline Protein contribution & $\begin{array}{l}\text { Contribution to animal protein intake in developing states ( } \% \text { animal protein } \\
\text { from fish, where feasible at the level of rural and urban areas) }\end{array}$ \\
\hline Micronutrients & $\begin{array}{l}\text { Contribution to nutrition in developing states (\% vitamin A, zinc and iron } \\
\text { derived from fish) }\end{array}$ \\
\hline Nutrition substitute & $\begin{array}{l}\text { Nutrition replacement costs (cost of next cheapest alternative source of } \\
\text { protein, vitamin A, zinc and iron) }\end{array}$ \\
\hline
\end{tabular}




\begin{tabular}{|c|c|}
\hline Variable/indicator & Description \\
\hline \multicolumn{2}{|l|}{ Trade } \\
\hline Exports & Catch exported ( $\%$ and value) at the smallest political scale possible \\
\hline Consumption market & Consumption market (local, non-local, size), end consumer \\
\hline Traceability & $\begin{array}{l}\text { Traceability of market/value/commercialization chain (\# of intermediaries } \\
\text { before reaching final consumer, etc.) }\end{array}$ \\
\hline \multicolumn{2}{|l|}{ Social development } \\
\hline Literacy & $\begin{array}{l}\text { Literacy in fishing communities (\% workforce), at the smallest political scale } \\
\text { possible }\end{array}$ \\
\hline Health services & $\begin{array}{l}\text { Access to health services (hospitals, clinics, medication, vaccines) provided by } \\
\text { government institutions }\end{array}$ \\
\hline Social security & Access to social security (retirement) provided by government institutions \\
\hline STDs & $\begin{array}{l}\text { Prevalence of HIVIAIDS and other STDs in fishing populations, as a measure of } \\
\text { health outcomes }\end{array}$ \\
\hline Substance abuse & Prevalence of addiction and dependence on alcohol/illegal stimulants \\
\hline Clean water & Access to water and sanitation \\
\hline Land tenure & Security of land tenure to home/property in coastal population \\
\hline Disaster loss & $\begin{array}{l}\text { Damages, losses, and impacts from natural or manmade disasters or conflicts. } \\
\text { Specify if it is loss to property (houses, fishing gear, boats), lives, fishing } \\
\text { infrastructure (ports, processing facilities, aquaculture equipment), or impacts } \\
\text { on fishing practices/satisfaction. }\end{array}$ \\
\hline Disaster recovery & $\begin{array}{l}\text { Disaster recovery from natural or manmade disasters or conflicts. Examples } \\
\text { include types of government help (purchase of equipment, rebuilding } \\
\text { ports, direct assistance to fishers), and fishers' recovery efforts (forming } \\
\text { new organizations, clean-up efforts, rebuilding infrastructure, purchasing } \\
\text { equipment). }\end{array}$ \\
\hline Age & Average age of fishers, with a focus on youth \\
\hline Offspring employment & $\begin{array}{l}\text { Economic activity of offspring (to measure intragenerational greying of } \\
\text { fishery) }\end{array}$ \\
\hline Urban proximity & Proximity of fishing communities or landing points to urban centres \\
\hline \multicolumn{2}{|l|}{ Environmental impacts } \\
\hline Production emissions & $\begin{array}{l}\text { Catch per unit of measure (e.g. ton, boat, effort) of carbon dioxide emissions, } \\
\text { emissions from post-harvest activities (e.g. wood burning for smoking fish) }\end{array}$ \\
\hline Stock assessment & Stock assessment available for stocks targeted by SSF (yes/no) \\
\hline $\begin{array}{l}\text { Conservation } \\
\text { participation }\end{array}$ & $\begin{array}{l}\text { Participation by fishers in environmental issues or conservation measures (i.e. } \\
\text { creation of fisheries refuges, fishing closures, no-fishing recovery zones, MPAs) }\end{array}$ \\
\hline \multicolumn{2}{|c|}{ Institutional arrangements } \\
\hline Governance structure & Self-governance structure (cooperative/associations or non-cooperative forms) \\
\hline Accountability & Accountability of fishers and the state (towards other fishers, the state) \\
\hline $\begin{array}{l}\text { Non-governmental } \\
\text { social services }\end{array}$ & Provision of social services ${ }^{28}$ by their fishing form of organization (yes/no) \\
\hline Regulatory structure & $\begin{array}{l}\text { Formal regulatory structure (permitting/TURFs/ITQs/etc.) with a focus on } \\
\text { regulations specifically targeted at SSF (e.g. SSF zones where industrial fishing } \\
\text { is prohibited) }\end{array}$ \\
\hline $\begin{array}{l}\text { Governance } \\
\text { participation }\end{array}$ & $\begin{array}{l}\text { Participation in decision-making processes related to fisheries governance } \\
\text { (regulatory, operational, etc.) }\end{array}$ \\
\hline \multicolumn{2}{|l|}{ Type of fishery involved } \\
\hline Gear change & Changes of fishing gear used by fishers in a community throughout the year \\
\hline Gear ownership & $\begin{array}{l}\text { Ownership of fishing means of production (\% or items: motor, boat, fishing } \\
\text { gear) }\end{array}$ \\
\hline
\end{tabular}

28 E.g. heath services, retirement security, etc. 


\section{Objective and methodology of this background paper}

\section{Objective of this paper}

To inform the design of the Hidden Harvest 2 study, this paper aims to provide an inventory of available data and information on SSF produced since 2011, and various methodologies employed to collect that data. Essentially, the paper aims to help identify the data needed and available to expand the arguments for policy investment and support to SSF.

\section{Methodology used}

To conduct an inventory of available data and information, the following steps were completed:

1. Global data sets were synthesized, including:

a. FAO global fisheries production statistics recorded in the FISHSTAT database;

b. FAO food balance sheets recorded in the FAOSTAT FBS database (the Organization's new Global Food Composition Database for Fish and Shellfish is also noted for further review);

c. Sea Around Us Project (SAUP) reconstructions of global fishing catch recorded in the SAUP database at the University of British Columbia;

d. Prof. Reg Watson's database of global marine fisheries catch at the Institute for Marine and Antarctic Studies (IMAS) at the University of Tasmania; and

e. The Too Big To Ignore (TBTI) network's Information System on Small-Scale Fisheries (ISSF).

2. Scientific literature published since 2011 was searched for a list of indicators (i.e. variables, concepts) measured empirically in SSF, based upon the Basurto library and database of all journal publications in English on SSF from 1960 to 2016 (ongoing at $\mathrm{n}=2$ 693). This search recorded examples where indicators have been empirically measured since 2011 and published in the scientific literature, and the spatial scale at which they were measured. See Appendix 2 for more details on the methodology used.

3. Grey literature published since 2011 was reviewed ad hoc, with a focus on publications from FAO and WorldFish Center, to capture additional examples of empirical measures of SSF activity and socio-economic contributions, as well as emerging global data collection efforts.

On the basis of these sources of information, the table of indicators proposed in the Introduction has been divided into three tiers of indicators based on data availability (see Chapter IV):

1. Tier 1 being those same indicators estimated in the first Hidden Harvest report;

2. Tier 2 being those indicators where the inventory suggests data is likely available; and

3. Tier 3 being those indicators where data is considered scarce.

Given the diversity of types of indicators, and the availability and reliability of data across different contexts, no one methodology or data collection instrument is likely to be feasible. Rather, mixed methods from multiple data sources will be required to clarify the global picture of SSF activity and socio-economic contributions. For this reason, a range of methods for measuring the different indicators has been employed in examples and scientific literature to date. 


\section{Defining small-scale fisheries as units of analysis}

The world's capture fisheries are incredibly diverse, with the term encompassing a wide range of activities, from catching fish with a spear, to operating nets from large fishing vessels containing on-board freezers and helicopter pads, to handling and processing tuna for canning (World Bank, FAO and WorldFish, 2012). As an economic activity, these fisheries are often characterized by their operational scale, from smallto large-scale activity, though on a continuum rather than a clear differentiation (a small-scale fishery in one country may be considered a medium-scale fishery in another) (HLPE, 2014). While the term first gained attention with Thomson's (1980) Table comparing measures of small- and large-scale fisheries, some 37 years later no single, agreed definition exists (FAO, 2015). Rather, SSF have often been categorized according to a range of characteristics such as location, resource targeted or purpose (i.e. commercial, subsistence or recreational), or often by the scale of technology used (FAO, 2016b). Based in part on the scale of technology used, the world's capture fisheries are frequently divided into "small-scale fisheries" and "large-scale fisheries", or alternatively, "subsistence fisheries", "artisanal fisheries" and "industrial fisheries" (Berkes et al., 2001; FAO, 2016c; World Bank, FAO and WorldFish, 2012).

Perhaps most definitively, small-scale fisheries have been described or characterized by the FAO Working Party on Small-Scale Fisheries as follows:

"Small-scale fisheries can be broadly characterized as a dynamic and evolving sector employing labour-intensive harvesting, processing and distribution technologies to exploit marine and inland water fishery resources. The activities of this subsector, conducted full time or part time, or just seasonally, are often targeted on supplying fish and fishery products to local and domestic markets, and for subsistence consumption. Export-oriented production, however, has increased in many small-scale fisheries during the last one to two decades because of greater market integration and globalization. While typically men are engaged in fishing and women in fish processing and marketing, women are also known to engage in near-shore harvesting activities and men are known to engage in fish marketing and distribution. Other ancillary activities such as net-making, boatbuilding, engine repair and maintenance, etc. can provide additional fishery-related employment and income opportunities in marine and inland fishing communities. Small-scale fisheries operate at widely differing organizational levels ranging from self-employed single operators through informal microenterprises to formal sector businesses. This subsector, therefore, is not homogenous within and across countries and regions, and attention to this fact is warranted when formulating strategies and policies for enhancing its contribution to food security and poverty alleviation" (FAO, 2003).

Similarly, in 2014 the SSF Guidelines were adopted and describe SSF as follows: "Small-scale and artisanal fisheries, encompassing all activities along the value chain - pre-harvest, harvest and post-harvest - undertaken by men and women play an important role in food security and nutrition, poverty eradication, equitable development and resource utilization ... Small-scale fisheries represent a diverse and dynamic subsector, often characterized by seasonal migration. The precise characteristics of the subsector vary depending on the location; indeed small-scale fisheries tend to be strongly anchored in local communities, reflecting often historic links to adjacent fishery resources, traditions and values, and supporting social cohesion" (FAO, 2015). 


\section{Shared global characteristics of SSF according to FAO}

- Highly dynamic

- Labour-intensive (with labour often the largest component of operating costs)

- Require a relatively low capital investment in boats and equipment per fisher on board compared with more industrialized operations

- Employ a wide range of low-level fishing technology with low catch per fishing craft and productivity per fisher (using relatively smaller vessels in a given region or in some cases none at all, e.g. beach seines or fish traps)

- Cover a relatively short geographic range (though migration is a feature of many small-scale fishers)

- Target multiple species

- Require minimal infrastructure for landing, with catch sold at scattered landing points

Sources: FAO 2016a; FAO 2008 - 2017; Béné 2006; in Basurto et al., forthcoming.

As these descriptions suggest, globally small-scale fisheries have evolved and diversified at a breakneck pace, where the lines defining scale have been bridged in particular through the integration of markets, technology transfers and changing socio-economic contexts (Mills et al., 2011). Indeed in some if not many countries, a general evolution from small-scale toward large-scale fisheries has taken place (Berkes et al., 2001), for example modernizing wooden canoes by equipping them with outboard engines (Chuenpagdee et al., 2006). Given this diversity and dynamism, achieving global consensus on a definition may not be possible.

\section{Results: Inventory of available data}

\section{Synthesis of the status of global data sets available}

The FAO FishStatJ database remains the backbone of any efforts to measure fisheries production, and since 2011 has formed the basis of two additional databases: the SAUP database and Prof. Watson's database at IMAS. Additionally, in 2016 TBTI created the ISSF to crowdsource research and measurements on SSF activity and contributions, captured in a database of SSF profiles. These and other relevant global efforts or data sets are described in more detail below.

The FishStatJ database contains statistics for fish catch (in live weight) by country, from the early 1950s to the present, based on standardized questionnaires completed each year by member countries and submitted to FAO (FAO, 1990-2017). As such, each national fishery statistical programme around the world functions as a component of an international data set maintained at FAO (FAO, 1990-2017). From this data set, FAO calculates global fish production and maintains the FishStatJ database with production volumes from 1950 to 2015 (FAO, 1990-2017). This database is a global and publicly available data set on fish catch reported when vessels offload (i.e. "fishery landings"), containing information on 2076 statistical taxonomic categories 
corresponding to the species, genus, family or higher taxonomic level, as well as trade statistics and market data where available (Garcia, 2009; FAO, 2017).

Aggregating statistics of the locations, timing and volumes of fish caught, as well as the identity of the harvester, is not without challenges. Since 1954 FAO has agreed that fish catches would be assigned to the country of the flag flown by the fishing vessel, or if not flying a flag, the country in which the vessel is registered (FAO, 1990-2017). The challenges that stem from organizing fish catch data by the flag States of fishing vessels are (among others) that vessels may fly "flags of convenience" that are issued by a country as a third party but indicate little of the origin of the vessel; vessels may then transfer the catch to another vessel of a different flag (either at sea or at port), and/ or when a fishing vessel lands its catch in a foreign port (FAO, 1990-2017). Additional challenges include under-reporting by vessels, illegal catches that are not recorded, and catches that are discarded at sea and never recorded upon landing (FAO, 1990-2017; Garcia, 2009). The reporting parameters were established long before countries' jurisdiction over the ocean extended to 200 nautical miles from the coastline, so countries' reports on landings from vessels flying their flag do not distinguish where the fish was caught, but rather report the origin of the catch landed with reference to the FAO main fishing $\operatorname{area}^{29}$ (Garcia, 2009). Additionally, for purposes of Hidden Harvest 2, countries reporting to FAO do not disaggregate catches by operational scale, i.e. by small- or large-scale operators, and often may not capture SSF catches in national statistical systems (Garcia, 2009; de Graaf et al., 2011). In summary, FishStatJ provides the official records of the live weight of catches of fish species groups by: (i) country to which the harvester is flagged, and (ii) the FAO main fishing area of origin. Finally, FishStatJ contains statistics on the annual imports and exports of fishery commodities by country in terms of volume and value since 1976 (FAO, 2017).

FAO food balance sheets measure the supply of fish available for consumption by a population during a specified reference period, by calculating the available supply based on production plus imports minus exports, in liveweight equivalents that are contained in the FAOSTAT database (FAO, 2008; Needham and Funge-Smith, 2015). This database provides the only global source of standardized apparent consumption data, which allows time series to be made - however, the data reflect apparent consumption, which often results in overestimation where there are for example high cross-border trades not captured in export statistics (Needham and Funge-Smith, 2015), or high rates of loss due to spoilage. These food balance sheets cannot provide information on variability within country or between subpopulations and groups, which would come from household food consumption surveys (typically estimating edible quantities consumed as opposed to apparent consumption of liveweight equivalents in food balance sheets) (FAO, 2008; Needham and Funge-Smith, 2015).

Additionally, FAO has recently launched a Global Food Composition Database for Fish and Shellfish, providing nutrient values for selected fish, crustaceans and molluscs in raw, cooked and processed form, covering data on proximates, minerals, vitamins, amino acids and fatty acids (FAO, 2016d). This database has not yet been synthesized for this paper, but may likely provide an important source of information for SSF.

The Sea Around Us Project (SAUP) at the University of British Columbia has aimed to address some of the previously mentioned challenges in the FAO marine fisheries data set as a result of under-reporting, discards and illegal fishing, by reviewing

$29 \mathrm{FAO}$ has classified eight major inland fishing areas and 19 major marine fishing areas, internationally established for fishery statistical purposes (FAO, 2017). 
additional information from regional organizations, national data sets, foreign fishing agreements, spatial distribution of species, and estimates from literature and other data sources (Watson et al., 2004). Building on the Organization's data set and supplementing it with this additional information, the SAUP has "reconstructed" fish catches by EEZs, large marine ecosystems and FAO main fishing areas from 1950 to 2010 (using taxa known to be found in a given location), and disaggregated these catches by scale (large-scale, small-scale, subsistence and recreational) (Zeller and Pauly, 2016). The catch reconstructions were developed based on the following seven steps:

- Identification, sourcing and comparison of baseline reported catch, based on a comparison of the FAO data set to nationally reported data in order to identify catches taken "elsewhere" in other EEZs or in areas beyond national jurisdiction (ABNJ), as many national data sets do not necessarily include catches by fleets flagged to that country but fishing and/or landing catches in other EEZs;

- Identification of missing data components based on extensive literature searches and consultations with local experts - disaggregating catches by scale, and into those landed or discarded;

- Sourcing of available alternative information sources on missing data identified in the previous step from expert consultations, scientific and grey literature, etc.;

- Development of data "anchor points" in time for each missing data component, and expansion of this data to estimates for the EEZ;

- Interpolation for time periods between data anchor points, generally via per capita (or per fisher) catch rates for non-commercial sectors;

- Estimation of total catch time series; and

- Quantifying the uncertainty associated with each reconstruction (Zeller and Pauly, 2016)

Prof. Reg Watson's database at IMAS at the University of Tasmania also estimates disaggregated marine catch data according to location in the ocean, based on a data set collected since 1999 and following methods somewhat similar to the SAUP database (Watson, 2017). The data was collected from a range of the best public sources (the FAO data set, the SAUP database and grey literature/public reports), harmonized into a single data set with common coding and overlapping data removed, and mapped to 30-min. spatial cells using information on the reported fished taxon's distribution, the behaviour and access of the reported fishing fleets, and any area description provided (Watson, 2017). The result was a mapped data set of catch rates (tonnes per square kilometre of ocean) for each spatial cell separated by year (from 1950 to 2014), fishing nation and fished taxa (Watson, 2017). This data set was further broken down by fishing gear type used, based on associations with the year/country/taxa, and subsequently the catch rate of illegal and unreported landings was estimated for each data record (Watson, 2017). Last, and particularly relevant for Hidden Harvest 2, total catches were disaggregated to small- and large-scale catches by: (i) applying the estimated small-scale fishing rates from Chuenpagdee et al. (2006) to each cell within 200 kilometres of the shore and with depths of 50 metres or less, (ii) subtracting this estimate from the total catch, and (iii) assuming the remainder as large-scale (Watson, 2017). In summary, using the FAO data set as the backbone, public sources of reported fisheries landings were harmonized and mapped to spatial cells based on taxonomic and fishing fleet considerations, associated with fishing gear, supplemented with estimates of illegal and unreported catches as well as discards, and disaggregated 
between small- and large-scale (Watson, 2017). Of note, mapping catch to location at this smaller resolution allows for better estimates of fuel usage and greenhouse gas emissions (Watson, 2017).

TBTI's Information System on Small-Scale Fisheries (ISSF) crowdsources information on various aspects of SSF from researchers around the world, including "SSF profiles" reporting measures for a standard set of 30 indicators of the characteristics of a given fishery. ${ }^{30}$ Of the 165 SSF profiles included in the ISSF database, 49 were entered in 2010 or after with data for at least half of the indicators, excluding high-income countries. These 49 SSF profiles were located in 24 countries, representing at least 67 353 households (based on those profiles where the total number of households in the location was recorded). Roughly two-thirds of these SSF profiles described fisheries at a substate spatial scale equivalent to a village or group of villages. See Appendix 2 for more detail.

Global and national census, and HIES data sets can potentially provide a snapshot of the demographics of SSF communities and activity. The UN Statistics Division collects population census data sets from national statistical offices of member countries via questionnaires, from 1995 to the present. ${ }^{31}$ More specifically, some 15-20 countries have included items on fisheries in the FAO World Programme for the Census of Agriculture (WCA) 2010 round (Srivastava and Tsuji, 2016). Since that time, guidelines for census/surveys of SSF have been discussed (Srivastava and Tsuji, 2016), and in 2015 FAO published the Guidelines to Enhance Fisheries and Aquaculture Statistics through a Census Framework (Gee, 2015). These Guidelines suggest a core set of measures of SSF activities and socio-economic contributions that should be collected in order to monitor SSF performance and sustainability, defined on the basis of the core data items included in the 2012 Global Strategy to improve Agricultural and Rural Statistics (Gee, 2015).

A global database of aid to ocean fisheries has been created to record grants and concessional loans active in the year 2015 provided by philanthropies, government aid agencies, regional development banks and multilateral aid agencies, based on the Foundation Center Database and publicly available databases, grey literature, websites, and verification with the agencies' staff where possible (Basurto et al., 2017). Additionally, a broader global ocean aid database has been launched by the Foundation Center, drawing upon its philanthropy grant data and official development assistance (ODA) data from the Organisation for Economic Co-operation and Development $(\mathrm{OECD})^{3.32}$

\section{Synthesis of additional SSF measures recorded in the scientific literature since 2011}

In order to assess potential measures of SSF activity and socio-economic contributions in addition to those estimated in the first Hidden Harvest, a global library and database of the scientific literature on SSF since $1960(\mathrm{n}=2$ 693) was reviewed. All articles published since 2011 were reviewed to determine if a set of indicators drawn from the table proposed in the Introduction were measured empirically in any cases, and if so at what spatial scale (note - only those indicators additional to the ones estimated in Hidden Harvest were searched).

30 See http://toobigtoignore.net/e-book-ismall-scale fisheries -small-scale-fisheries-profiles/. 31 See https://unstats.un.org/unsd/demographic/products/dyb/dybcensusdata.htm. 32 See http://fundingtheocean.org/. 
The categories for these 36 indicators included the following (see Appendix 3 for the list of the 36 indicators searched):

- Production and utilization

- Employment

- Efficiency

- Economic contribution

- Food security and nutrition

- Trade

- Social development

- Environmental impacts

- Institutional arrangements

- Type of fishery involved

Within the scientific literature on SSF from 2011 until the end of 2016, 152 measures of one of the 36 indicators was found in at least a total of 54 countries, with theory, methods and proofs of concept available for most indicators. Similar to the SSF profiles in the ISSF, most studies have been conducted at a relatively small spatial scale (i.e. a very limited geographical coverage), and in some cases do not make a clear distinction between small- and large-scale fisheries. Roughly 20 percent of these indicators have been studied at all scales - substate, state and national - and a smaller number have been studied at the global level: literacy, protein intake, sexually transmitted diseases (STDs) and regulatory structure variables. If only these indicators were added to those collected in the first Hidden Harvest, already a more detailed global picture would be expected to emerge of SSF.

\section{Synthesis of selected grey literature}

Given the absence of any one library of grey literature on SSF, an ad hoc review was undertaken based on consultations with experts at FAO and WorldFish Center. Key studies conducted since the first Hidden Harvest include:

- FAO report on housebold consumption of fish and fish products in Asia-Pacific (Needham and Funge-Smith, 2015), which synthesized national household consumption surveys across the region to present per capita fish consumption by country (including disaggregating between urban and rural), including: Bangladesh, Bhutan, Cambodia, China, Cook Islands, Federated States of Micronesia, Fiji, French Polynesia, India, Indonesia, Kiribati, Lao People's Democratic Republic, Mongolia, Myanmar, Nauru, New Caledonia, Niue, Pakistan, Palau, Papua New Guinea, Philippines, Samoa, Solomon Islands, Sri Lanka, Thailand, Timor-Leste, Tonga, Tuvalu, Vanuatu, Viet Nam, and Wallis and Futuna Islands;

- FAO report on fisheries in the drylands of sub-Sabaran Africa (Kolding et al., 2016), synthesizing estimates of inland fisheries catch in Africa in comparison with official records, and the relationship of this catch and productivity to unpredictable rainfall;

- FAO report on the value of African fisheries (de Graaf and Garibaldi, 2014), calculating the contribution of African fisheries to GDP by country from the system of national accounts, though not disaggregated by small- or large-scale; and

- WorldFish report on fisheries, poverty and food security (Allison, 2011), including an index of fisheries dependency, based on the proportion of animal protein consumption provided by fish (nutrition indicator), the labour force 
involved in fisheries and aquaculture (employment) and the contribution to GDP (macroeconomic indicator), as well as illustrating trends in per capita fish protein supply alongside trends in export.

\section{Workshop Session 2: Where or how can we find the data, and what} methodologies should we use for data collection and analysis/extrapolation? The following section of this paper, entitled "Results: Proposed available indicators and data collection methods," corresponds to the second session of the workshop.

\section{Results: Proposed available indicators and data collection methods}

\section{Proposed tier 1 of indicators to be measured in Hidden Harvest 2}

Based on the various data sets, articles and case studies referenced previously, the first tier of indicators proposed for measurement in Hidden Harvest 2 are the same basic measures taken in the first study, focusing largely on production and utilization, employment, and efficiency. With the exception of production data, and possibly available census data, the majority of this data would still be expected to be collected through case studies at the national level.

\begin{tabular}{|c|c|c|}
\hline Indicator & Data source & Methodology \\
\hline \multicolumn{3}{|c|}{ Production and utilization } \\
\hline $\begin{array}{l}\text { SSF catch by national } \\
\text { jurisdiction (tonnes) }\end{array}$ & $\begin{array}{l}\text { SAUP database, Watson database } \\
\text { National statistics and reports }\end{array}$ & $\begin{array}{l}\text { Case studies to access national and } \\
\text { subnational statistics and reports, } \\
\text { compared with global databases }\end{array}$ \\
\hline $\begin{array}{l}\text { SSF catch landed } \\
\text { value }\end{array}$ & $\begin{array}{l}\text { Swartz, Sumaila and Watson (2013) } \\
\text { expanded work begun by Sumaila } \\
\text { et al. (2007) to construct a global } \\
\text { database of ex-vessel prices to } \\
\text { multiply by the catch to calculate } \\
\text { landed value, as did Melnychuk et al. } \\
\text { (2016). Both predominantly record } \\
\text { prices from large-scale catch, but may } \\
\text { be applicable for some species or } \\
\text { species group. }\end{array}$ & $\begin{array}{l}\text { Where case studies are not able to } \\
\text { provide locally appropriate ex-vessel } \\
\text { prices based on markets and } \\
\text { consumption, global databases could } \\
\text { be used in some cases. }\end{array}$ \\
\hline $\begin{array}{l}\text { Discards as \% of total } \\
\text { catch }\end{array}$ & $\begin{array}{l}\text { Watson database National reports, } \\
\text { consultations }\end{array}$ & $\begin{array}{l}\text { Case studies to access national } \\
\text { statistics and reports, expert } \\
\text { consultations }\end{array}$ \\
\hline \multicolumn{3}{|l|}{ Employment } \\
\hline SSF fishers (\#) & $\begin{array}{l}\text { National statistics and reports, } \\
\text { consultations } \\
\text { National SSF vessel registries, e.g. } \\
\text { West Africa national canoe registries } \\
\text { created since } 2011 \text { with support } \\
\text { of West Africa Regional Fisheries } \\
\text { Program (World Bank, 2009) }\end{array}$ & $\begin{array}{l}\text { Case studies to access national } \\
\text { statistics and reports }\end{array}$ \\
\hline $\begin{array}{l}\text { SSF post-harvest jobs } \\
(\#)\end{array}$ & $\begin{array}{l}\text { National statistics and reports, } \\
\text { consultations }\end{array}$ & $\begin{array}{l}\text { Case studies to access national } \\
\text { statistics and reports }\end{array}$ \\
\hline Total workforce (\#) & $\begin{array}{l}\text { National statistics and reports, } \\
\text { consultations } \\
\text { Possibly census data }\end{array}$ & $\begin{array}{l}\text { Sum of fishers and post-harvest jobs } \\
\text { For illustration, compare total \# of } \\
\text { ocean SSF jobs to all other sectors of } \\
\text { ocean economy (OECD, 2016) }\end{array}$ \\
\hline
\end{tabular}




\begin{tabular}{|c|c|c|}
\hline Indicator & Data source & Methodology \\
\hline $\begin{array}{l}\text { Women as a } \% \text { of } \\
\text { total workforce }\end{array}$ & $\begin{array}{l}\text { National statistics and reports, } \\
\text { consultations } \\
\text { ISSF SSF Profiles } \\
\text { Possibly census data, e.g. Harper et } \\
\text { al. (2017) }\end{array}$ & $\begin{array}{l}\text { Case studies } \\
\text { See Harper et al. (2017) example of } \\
\text { gender dimensions of fisheries from } \\
\text { national level statistics in Mexico, } \\
\text { Peru, Senegal, South Africa and Viet } \\
\text { Nam }\end{array}$ \\
\hline \multicolumn{3}{|l|}{ Efficiency } \\
\hline $\begin{array}{l}\text { Catch per SS fisher } \\
\text { (tonnes) }\end{array}$ & National statistics and reports & $\begin{array}{l}\text { Case studies to estimate catch rates } \\
\text { based on national reports and } \\
\text { statistics of SSF effort }\end{array}$ \\
\hline $\begin{array}{l}\text { SSF catch per ton of } \\
\text { fuel }\end{array}$ & & Case studies \\
\hline
\end{tabular}

\section{Proposed tier 2 of indicators to be measured in Hidden Harvest 2}

This tier includes indicators additional to those collected systematically in the first Hidden Harvest study, that are considered likely to be available at the global level based on studies conducted since 2011, or at the national level in many of the case studies given the recent scientific literature. Additionally, based on the number of case studies available in the literature at a smaller spatial scale, a larger number of indicators are suggested to likely be available in national case studies.

Those indicators considered likely to be available at the national or global level based on recent literature include the following:

\begin{tabular}{|c|c|c|c|}
\hline Indicator & Methodology & $\begin{array}{l}\text { Potential data collection } \\
\text { strategies }\end{array}$ & $\begin{array}{l}\text { Some useful illustrative } \\
\text { studies }\end{array}$ \\
\hline \multicolumn{4}{|c|}{ Food security and nutrition } \\
\hline $\begin{array}{l}\text { Protein } \\
\text { Contribution }\end{array}$ & $\begin{array}{l}\text { Calculate the } \\
\text { contribution of SSF } \\
\text { products to the overall } \\
\text { protein intake by } \\
\text { targeted populations } \\
\text { ( } \% \text { animal protein } \\
\text { originating from fish } \\
\text { products from SSF), } \\
\text { through national food } \\
\text { balance sheets to } \\
\text { indirectly estimate fish } \\
\text { availability, household } \\
\text { surveys for indirect } \\
\text { estimation, and } \\
\text { short- or long-term } \\
\text { consumption surveys. }\end{array}$ & $\begin{array}{l}\text { Compile worldwide } \\
\text { production of the main } \\
\text { sources of animal protein } \\
\text { over the period 1960- } \\
\text { 2010. Source: FAOSTAT } \\
\text { and Food Balance Sheets } \\
\text { (Béné et al., 2015) } \\
\text { Needham and Funge- } \\
\text { Smith (2015) per capita } \\
\text { consumption in Asia- } \\
\text { Pacific }\end{array}$ & $\begin{array}{l}\text { Other illustrative } \\
\text { citations: } \\
\text { Bell et al. (2015) - Papua } \\
\text { New Guinea } \\
\text { Coetzee et al. (2015) - } \\
\text { South Africa } \\
\text { Teh, Teh and Sumaila } \\
\text { (2011) - Sabah, Malaysia } \\
\text { Barnes-Mauthe (2013) - } \\
\text { Madagascar } \\
\text { Note: Fishing for a Future } \\
\text { (2016) suggest that an } \\
\text { ideal diet includes a } \\
\text { contribution by fish of } \\
\text { 20\% protein intake }\end{array}$ \\
\hline \multicolumn{4}{|c|}{ Social development } \\
\hline Age & $\begin{array}{l}\text { Survey average age of } \\
\text { fishers for a particular } \\
\text { area }\end{array}$ & $\begin{array}{l}\text { Case studies to mine } \\
\text { survey data for coastal } \\
\text { residents where SSF } \\
\text { activities predominate } \\
\text { Census data potentially } \\
\text { available }\end{array}$ & $\begin{array}{l}\text { Carr and Heyman (2012) } \\
\text { - United States Virgin } \\
\text { Islands } \\
\text { Begossi et al. (2012) - } \\
\text { Brazil } \\
\text { Le Xuan (2012) - Viet } \\
\text { Nam } \\
\text { Fernandes (2012) - } \\
\text { Guinea-Bissau } \\
\text { Percin et al. (2012) - } \\
\text { Turkey }\end{array}$ \\
\hline
\end{tabular}




\begin{tabular}{|c|c|c|c|}
\hline Indicator & Methodology & $\begin{array}{l}\text { Potential data collection } \\
\text { strategies }\end{array}$ & $\begin{array}{l}\text { Some useful illustrative } \\
\text { studies }\end{array}$ \\
\hline STDS & $\begin{array}{l}\text { Prevalence of HIVIAIDS } \\
\text { and other STDs in SSF } \\
\text { populations }\end{array}$ & $\begin{array}{l}\text { Case studies to obtain } \\
\text { information from } \\
\text { national health offices } \\
\text { and restricted to areas } \\
\text { where SSF activities } \\
\text { predominate }\end{array}$ & $\begin{array}{l}\text { Illustrative citations: } \\
\text { Béné et al. (2015) - global } \\
\text { Robles-Zavala (2014) - } \\
\text { Mexico }\end{array}$ \\
\hline \multicolumn{4}{|c|}{ Institutional arrangements } \\
\hline $\begin{array}{l}\text { Regulatory } \\
\text { structures }\end{array}$ & $\begin{array}{l}\text { Account for the formal } \\
\text { regulatory structure in } \\
\text { place (e.g. permitting/ } \\
\text { TURFs/ITQs, etc.) }\end{array}$ & $\begin{array}{l}\text { Case studies to obtain } \\
\text { information from } \\
\text { national fisheries offices } \\
\text { (Purcel et al., 2013) } \\
\text { ISSF SSF Profiles }\end{array}$ & $\begin{array}{l}\text { Other illustrative } \\
\text { citations: } \\
\text { Fernandez-Boan et al. } \\
\text { (2012) - Spain } \\
\text { Arceo et al. (2013) - } \\
\text { France }\end{array}$ \\
\hline Aid & $\begin{array}{l}\text { Measure financial flows } \\
\text { of aid explicitly targeted } \\
\text { to support SSF }\end{array}$ & $\begin{array}{l}\text { Fisheries aid database } \\
\text { (Basurto et al., } \\
\text { forthcoming); Funding } \\
\text { the Ocean database }\end{array}$ & \\
\hline
\end{tabular}

Additionally, a range of other indicators may likely be available in case studies but at a smaller spatial scale (e.g. substate or state level within a country) based on the inventory of literature, as shown in the following table:

\begin{tabular}{|c|c|c|c|}
\hline Indicator & Methodology & $\begin{array}{l}\text { Potential data } \\
\text { collection strategies }\end{array}$ & $\begin{array}{l}\text { Some useful } \\
\text { illustrative studies }\end{array}$ \\
\hline \multicolumn{4}{|c|}{ Production and utilization } \\
\hline Use & $\begin{array}{l}\text { Measures of end use of } \\
\text { catch (consumption vs non- } \\
\text { consumption) }\end{array}$ & $\begin{array}{l}\text { Case studies to } \\
\text { synthesize national } \\
\text { reports and/or local } \\
\text { measurements }\end{array}$ & $\begin{array}{l}\text { Illustrative citations: } \\
\text { Tesfamichael and } \\
\text { Mohamud (2016), } \\
\text { Eritrea; Pinto et al. } \\
\text { (2015), Brazil }\end{array}$ \\
\hline \multicolumn{4}{|l|}{ Employment } \\
\hline $\begin{array}{l}\text { Indigenous } \\
\text { or ethnic } \\
\text { workforce }\end{array}$ & $\begin{array}{l}\text { Indigenous persons or ethnic } \\
\text { minorities represented in the } \\
\text { fishing workforce }(\%)\end{array}$ & $\begin{array}{l}\text { Case studies } \\
\text { synthesizing available } \\
\text { questionnaires, } \\
\text { empirical study }\end{array}$ & $\begin{array}{l}\text { Illustrative citations: } \\
\text { Paudel et al. (2016), } \\
\text { Nepal; Basurto et al. } \\
\text { (2012), Mexico }\end{array}$ \\
\hline Dependents & Fisher household dependents & $\begin{array}{l}\text { Case studies to } \\
\text { estimate multipliers } \\
\text { for SS fishers } \\
\text { Household surveys, } \\
\text { potentially drawing } \\
\text { from census data }\end{array}$ & $\begin{array}{l}\text { Illustrative citations: } \\
\text { Gilbert et al. (2014), } \\
\text { Malaysia (national } \\
\text { scale); } \\
\text { Hill et al. (2012), } \\
\text { Philippines (national } \\
\text { scale) }\end{array}$ \\
\hline Disadvantaged & $\begin{array}{l}\text { Employment of disadvantaged } \\
\text { segments of the population } \\
\text { (elderly, widowed, orphaned, } \\
\text { disabled) }\end{array}$ & $\begin{array}{l}\text { Case studies to } \\
\text { collect available data } \\
\text { from surveys and } \\
\text { interviews }\end{array}$ & $\begin{array}{l}\text { Illustrative citations: } \\
\text { Dresdner et al. } \\
\text { (2015), Chile; Muller } \\
\text { et al. (2016), Brazil; } \\
\text { Coetzee et al. (2015), } \\
\text { South Africa }\end{array}$ \\
\hline
\end{tabular}




\begin{tabular}{|c|c|c|c|}
\hline Indicator & Methodology & $\begin{array}{l}\text { Potential data } \\
\text { collection strategies }\end{array}$ & $\begin{array}{l}\text { Some useful } \\
\text { illustrative studies }\end{array}$ \\
\hline \multicolumn{4}{|l|}{ Efficiency } \\
\hline CPUE & $\begin{array}{l}\text { CPUE or catch rate is frequently } \\
\text { the most useful index for long- } \\
\text { term monitoring of a fishery, } \\
\text { and often used as an index of } \\
\text { stock abundance - though care } \\
\text { should be taken in relying solely } \\
\text { on it for assumptions about } \\
\text { trends in stock size. In general, } \\
\text { by maintaining a time series of } \\
\text { CPUE and total landings by fleets } \\
\text { (e.g. gear or boat category), } \\
\text { commercial species group, } \\
\text { fishing area and fishing season, } \\
\text { overfishing should be detectable } \\
\text { (Bartley et al., 2015). } \\
\text { However, calculating for a } \\
\text { standard unit of effort may be } \\
\text { challenging (e.g. fishing days). }\end{array}$ & $\begin{array}{l}\text { Case studies to } \\
\text { compile catch rates } \\
\text { for a standard unit } \\
\text { of effort } \\
\text { Watson database } \\
\text { uses catch rates } \\
\text { estimated in } \\
\text { Chuenpagdee et al. } \\
\text { (2006) }\end{array}$ & $\begin{array}{l}\text { Illustrative citations: } \\
\text { Damasio et al. (2015), } \\
\text { Brazil; Beitl (2014), } \\
\text { Ecuador }\end{array}$ \\
\hline \multicolumn{4}{|l|}{ Trade } \\
\hline Exports & $\begin{array}{l}\text { Disaggregate FAO fish } \\
\text { commodity trade statistics } \\
\text { based on case studies to obtain } \\
\text { national export data }\end{array}$ & $\begin{array}{l}\text { FishStatJ contains } \\
\text { aggregated } \\
\text { statistics on the } \\
\text { annual imports and } \\
\text { exports of fishery } \\
\text { commodities by } \\
\text { country in terms of } \\
\text { volume and value } \\
\text { since } 1976 . \\
\text { Case studies to } \\
\text { obtain national data, } \\
\text { as well as interviews/ } \\
\text { surveys }\end{array}$ & $\begin{array}{l}\text { Illustrative citations: } \\
\text { Baigun et al. (2013), } \\
\text { Argentina; } \\
\text { Lakasanawimol et al. } \\
\text { (2013), Thailand }\end{array}$ \\
\hline $\begin{array}{l}\text { Consumption } \\
\text { market }\end{array}$ & $\begin{array}{l}\text { Consumption market (local, } \\
\text { non-local, size), end consumer, } \\
\text { identified through case studies } \\
\text { that provide descriptions of } \\
\text { specific fisheries, interviews and } \\
\text { questionnaires }\end{array}$ & $\begin{array}{l}\text { Case studies, often } \\
\text { based on surveys and } \\
\text { interviews }\end{array}$ & $\begin{array}{l}\text { Illustrative citations: } \\
\text { Aheto et al. (2012), } \\
\text { Ghana; } \\
\text { Bos et al. (2012), } \\
\text { Philippines; } \\
\text { Adhuri et al. (2016), } \\
\text { Indonesia }\end{array}$ \\
\hline \multicolumn{4}{|c|}{ Social development } \\
\hline $\begin{array}{l}\text { Access to } \\
\text { health services } \\
\text { provided by } \\
\text { government } \\
\text { institutions }\end{array}$ & $\begin{array}{l}\text { Case studies to collect census } \\
\text { data or available surveys and } \\
\text { information on households in } \\
\text { fishing communities with access } \\
\text { to services }\end{array}$ & $\begin{array}{l}\text { Census data on } \% \text { of } \\
\text { households within } \\
\text { a given area with } \\
\text { access to health } \\
\text { services }\end{array}$ & $\begin{array}{l}\text { Illustrative citations: } \\
\text { Kalikoski et al. } \\
\text { (2012), Brazil; Tran } \\
\text { Thi Phung et al. } \\
\text { (2013), Viet Nam; } \\
\text { Aida Marin-Monroy } \\
\text { et al. (2016), Mexico }\end{array}$ \\
\hline Land tenure & $\begin{array}{l}\text { Case studies with surveys to } \\
\text { assess formal ownership of } \\
\text { homes in fishing communities, } \\
\text { or at a national level to assess } \\
\text { formal recognition of land } \\
\text { tenure in fishing communities, } \\
\text { based on legal frameworks }\end{array}$ & $\begin{array}{l}\text { National laws, } \\
\text { regulations } \\
\text { Surveys, } \\
\text { questionnaires }\end{array}$ & $\begin{array}{l}\text { Illustrative citations: } \\
\text { Islam, Yew, and } \\
\text { Viswanathan (2014), } \\
\text { Bangladesh; Perret } \\
\text { and Yuerlita (2014), } \\
\text { Indonesia; Bennett et } \\
\text { al. (2014), Thailand }\end{array}$ \\
\hline Social security & $\begin{array}{l}\text { Case studies with questionnaires } \\
\text { to fishing households concerning } \\
\text { access to social security } \\
\text { (retirement) provided by } \\
\text { government institutions }\end{array}$ & $\begin{array}{l}\text { Case studies } \\
\text { with surveys, } \\
\text { questionnaires }\end{array}$ & $\begin{array}{l}\text { Illustrative citations: } \\
\text { Leticia Bravo-Olivas } \\
\text { (2015), Turkey }\end{array}$ \\
\hline Disaster loss & $\begin{array}{l}\text { Damages, losses, and impacts } \\
\text { from natural or manmade } \\
\text { disasters or conflicts, captured } \\
\text { through surveys, questionnaires } \\
\text { and interviews }\end{array}$ & $\begin{array}{l}\text { Case studies } \\
\text { synthesizing survey, } \\
\text { interview and } \\
\text { questionnaire results }\end{array}$ & $\begin{array}{l}\text { Illustrative citations: } \\
\text { Pollnac and Kotowicz } \\
\text { (2012), Thailand; } \\
\text { Ernst et al. (2013), } \\
\text { Chile }\end{array}$ \\
\hline
\end{tabular}




\begin{tabular}{|c|c|c|c|}
\hline Indicator & Methodology & $\begin{array}{l}\text { Potential data } \\
\text { collection strategies }\end{array}$ & $\begin{array}{l}\text { Some useful } \\
\text { illustrative studies }\end{array}$ \\
\hline $\begin{array}{l}\text { Disaster } \\
\text { recovery }\end{array}$ & $\begin{array}{l}\text { Disaster recovery from natural or } \\
\text { manmade disasters or conflicts } \\
\text { based on surveys, questionnaires } \\
\text { and interviews }\end{array}$ & $\begin{array}{l}\text { Case studies } \\
\text { synthesizing survey, } \\
\text { interview and } \\
\text { questionnaire results }\end{array}$ & $\begin{array}{l}\text { Illustrative citations: } \\
\text { Munas and Lokuge } \\
\text { (2016), Sri Lanka }\end{array}$ \\
\hline $\begin{array}{l}\text { Urban } \\
\text { proximity }\end{array}$ & $\begin{array}{l}\text { Measure of landings and/or catch } \\
\text { within a given distance of urban } \\
\text { centres }\end{array}$ & $\begin{array}{l}\text { Case studies to } \\
\text { collect national } \\
\text { landings data; also } \\
\text { Watson databases } \\
\text { on catch by spatial } \\
\text { cell, within a given } \\
\text { distance from urban } \\
\text { centres }\end{array}$ & $\begin{array}{l}\text { Illustrative citations: } \\
\text { Marin et al. (2015), } \\
\text { Chile; Muallil et al. } \\
\text { (2013), Philippines }\end{array}$ \\
\hline \multicolumn{4}{|c|}{ Environmental impacts } \\
\hline $\begin{array}{l}\text { Stock } \\
\text { assessment }\end{array}$ & $\begin{array}{l}\text { Available stock assessments for } \\
\text { stocks targeted by SSF }\end{array}$ & $\begin{array}{l}\text { Case studies to } \\
\text { synthesize available } \\
\text { assessments }\end{array}$ & $\begin{array}{l}\text { Illustrative citations: } \\
\text { Tesfaye et al. (2015), } \\
\text { Ethiopia }\end{array}$ \\
\hline \multicolumn{4}{|c|}{ Institutional arrangements } \\
\hline $\begin{array}{l}\text { Governance } \\
\text { structure }\end{array}$ & $\begin{array}{l}\text { Description of self-governance } \\
\text { structures for SSF, based on a } \\
\text { range of empirical measures in } \\
\text { communities }\end{array}$ & $\begin{array}{l}\text { Case studies to } \\
\text { synthesize empirical } \\
\text { measures, including } \\
\text { from ISSF SSF profiles }\end{array}$ & $\begin{array}{l}\text { Illustrative citations: } \\
\text { Basurto et al. (2012), } \\
\text { Mexico; Cinner et al. } \\
\text { (2015), Kenya }\end{array}$ \\
\hline $\begin{array}{l}\text { Governance } \\
\text { participation }\end{array}$ & $\begin{array}{l}\text { Descriptions of decision-making } \\
\text { processes in SSF communities }\end{array}$ & $\begin{array}{l}\text { Case studies to } \\
\text { synthesize examples, } \\
\text { including from ISSF } \\
\text { SSF profiles }\end{array}$ & $\begin{array}{l}\text { Illustrative citations: } \\
\text { Fargier et al. (2014), } \\
\text { Costa Rica; Trimble, } \\
\text { Araujo, and Seixas } \\
\text { (2014), Brazil }\end{array}$ \\
\hline \multicolumn{4}{|c|}{ Type of fishery } \\
\hline Gear change & $\begin{array}{l}\text { Empirical measures of change of } \\
\text { fishing gear used by SS fishers } \\
\text { throughout the year }\end{array}$ & $\begin{array}{l}\text { Case studies to } \\
\text { synthesize surveys, } \\
\text { questionnaires, etc. }\end{array}$ & $\begin{array}{l}\text { Illustrative citations: } \\
\text { Vieira et al. (2013), } \\
\text { Brazil }\end{array}$ \\
\hline $\begin{array}{l}\text { Gear } \\
\text { ownership }\end{array}$ & Empirical measures of ownership & $\begin{array}{l}\text { Case studies to } \\
\text { synthesize empirical } \\
\text { measures }\end{array}$ & $\begin{array}{l}\text { Illustrative citations: } \\
\text { Wilson et al. (2016), } \\
\text { Dominican Republic }\end{array}$ \\
\hline
\end{tabular}

Of note, relatively few examples of measures of SSF economic impact were found (total output in the economy due to the output from SSF, such as boatbuilding, supplies, etc.). However in Malaysia, Teh, Teh and Sumaila (2011) used a fisheries output multiplier developed by Dyck and Sumaila (2010) to account for direct, indirect and induced economic effects of fishing - essentially tracking the flow of dollars from one industry to the next, in order to quantify how much output from industry $\mathrm{x}$ is required to produce a unit of output for industry $y$. 


\section{Proposed tier 3 of indicators to be measured in Hidden Harvest 2}

These indicators had relatively little data collected in the scientific literature, though they may be priorities for future data collection.

\begin{tabular}{|c|c|c|c|}
\hline Indicator & Methodology & Rationale & $\begin{array}{l}\text { Potential data } \\
\text { collection strategies }\end{array}$ \\
\hline Accountability & $\begin{array}{l}\text { Measured in three directions: } \\
\text { upward (towards higher-level } \\
\text { authorities), horizontal (toward } \\
\text { stakeholders in other sectors } \\
\text { or localities), and downward } \\
\text { (toward resource users and other } \\
\text { community members) (Ratner } \\
\text { and Allison, 2012) }\end{array}$ & $\begin{array}{l}\text { Questions of } \\
\text { accountability apply } \\
\text { equally to the } \\
\text { exercise of public and } \\
\text { private authority. } \\
\text { Issues of concern } \\
\text { include the degree } \\
\text { to which actors are } \\
\text { held accountable } \\
\text { in practice; the } \\
\text { relative strength of } \\
\text { upward, horizontal } \\
\text { and downward } \\
\text { accountabilities; and } \\
\text { the transaction costs } \\
\text { involved in keeping } \\
\text { decision-makers } \\
\text { accountable. }\end{array}$ & $\begin{array}{l}\text { Interviews and } \\
\text { surveys. Can } \\
\text { be measured } \\
\text { for different } \\
\text { mechanisms: } \\
\text { enforcement by } \\
\text { state agencies; rights } \\
\text { to legal recourse; } \\
\text { judicial process; } \\
\text { legal protections } \\
\text { for freedoms } \\
\text { of expression, } \\
\text { organizing, etc.; } \\
\text { enforcement } \\
\text { \& arbitration } \\
\text { mechanisms in } \\
\text { international accords. } \\
\text { (Stanford et al., } \\
\text { 2014) }\end{array}$ \\
\hline $\begin{array}{l}\text { Catch } \\
\text { emissions }\end{array}$ & $\begin{array}{l}\text { Estimate fuel use (relative } \\
\text { consumption) in relation to } \\
\text { landed fish (kg fuel.(t fish } \\
\text { landed)-1) (Freon et al., 2014) }\end{array}$ & & $\begin{array}{l}\text { In Peru, fuel use } \\
\text { estimates were } \\
\text { calculated from } \\
\text { thousands of } \\
\text { recorded trips } \\
\text { (data from IMARPE } \\
\text { surveys, 2005- } \\
\text { 2010), thousands } \\
\text { of recorded trip } \\
\text { durations and mean } \\
\text { engine fuel demand } \\
\text { (IMARPE surveys, } \\
\text { 2005-2010), and by } \\
\text { applying the speed } \\
\text { ratios from GPS data. } \\
\text { (Freon et al., 2014) }\end{array}$ \\
\hline $\begin{array}{l}\text { Access to clean } \\
\text { water }\end{array}$ & $\begin{array}{l}\text { Reports the } \% \text { of the population } \\
\text { of a municipality and a province } \\
\text { with access to safe water and } \\
\text { sanitation (Fabinyi et al., 2014) }\end{array}$ & & $\begin{array}{l}\text { In the Philippines, } \\
\text { study data source } \\
\text { was the Human } \\
\text { Development Report } \\
\text { of Palawan (HDR) } \\
\text { from 2005, based } \\
\text { on data from a } \\
\text { community-based } \\
\text { monitoring system } \\
\text { and complemented } \\
\text { with figures from the } \\
\text { National Statistics } \\
\text { Office. (Fabinyi et al., } \\
\text { 2014) }\end{array}$ \\
\hline $\begin{array}{l}\text { Household } \\
\text { economy }\end{array}$ & $\begin{array}{l}\text { Compare median incomes from } \\
\text { fishing and non-fishing activities } \\
\text { by women and men in fisher } \\
\text { families. (Thorpe et al., 2014) }\end{array}$ & & $\begin{array}{l}\text { Household income } \\
\text { surveys (Thorpe et } \\
\text { al., 2014) Possibly } \\
\text { census data }\end{array}$ \\
\hline $\begin{array}{l}\text { Offspring } \\
\text { employment }\end{array}$ & $\begin{array}{l}\text { Understand years of schooling } \\
\text { and years participating in } \\
\text { fishing to determine overlap or } \\
\text { substitution. (Broch, 2013) }\end{array}$ & & $\begin{array}{l}\text { Interviews with 7-18 } \\
\text { year-olds (Broch, } \\
\text { 2013) }\end{array}$ \\
\hline Subsidies & $\begin{array}{l}\text { Subsidy reliance as proportion of } \\
\text { capital from subsidies invested in } \\
\text { fleet/boats (Guyader et al., 2013) }\end{array}$ & & $\begin{array}{l}\text { Direct sample and } \\
\text { survey of small- } \\
\text { scale vessel owners } \\
\text { (Guyader et al., 2013) }\end{array}$ \\
\hline
\end{tabular}




\begin{tabular}{|c|c|c|c|}
\hline Indicator & Methodology & Rationale & $\begin{array}{l}\text { Potential data } \\
\text { collection strategies }\end{array}$ \\
\hline $\begin{array}{l}\text { Substance } \\
\text { abuse }\end{array}$ & $\begin{array}{l}\text { Investigate daily internal and } \\
\text { external routines and activities } \\
\text { of selected households. Also } \\
\text { count number of medical records } \\
\text { of addictions and family violence } \\
\text { within households to infer } \\
\text { impact of drug addiction on } \\
\text { community (Robles-Zavala, 2014). }\end{array}$ & & $\begin{array}{l}\text { Combination of } \\
\text { qualitative and } \\
\text { quantitative } \\
\text { methods: 1) key } \\
\text { informant interviews; } \\
\text { 2) participant } \\
\text { observations; } 3 \text { ) } \\
\text { records from health } \\
\text { centres (Robles- } \\
\text { Zavala, 2014) }\end{array}$ \\
\hline Traceability & $\begin{array}{l}\text { Trace flows of SSF products and } \\
\text { value. Conduct price analysis to } \\
\text { determine where value-added } \\
\text { activities and the distribution of } \\
\text { benefits occur along the value } \\
\text { chain using price data from } \\
\text { fishers, fish farmers, wholesalers, } \\
\text { processors, exporters and } \\
\text { retailers. }\end{array}$ & & $\begin{array}{l}\text { National level } \\
\text { statistics, surveys and } \\
\text { interviews }\end{array}$ \\
\hline
\end{tabular}

Several indicators were not found at all in the scientific literature since 2011, including:

- micronutrients;

- food waste - where the global data set for fish is weak (Fishing for a Future, 2016), while FAO estimates that roughly one-third of food produced for human consumption is lost or wasted globally - about 1.3 billion metric tonnes per year (FAO, 2011);

- nutrition substitutes; and

- non-governmental social services.

Given the proposed objective of Hidden Harvest 2 to provide policy-makers and supporters with reliable, validated data and information on SSF, the absence of data and case studies on the majority of the proposed indicators is disappointing: only one of the proposed indicators for food security and nutrition seems feasible. Essentially the contribution of fish to protein intake remains a viable indicator to measure in case studies and to extrapolate globally, but measures of micronutrient intake, availability and cost of nutrition substitutes, and levels of food waste, remain largely absent from global data sets and scientific literature. 
Summary of proposed indicators for Hidden Harvest 2, based on data availability

\begin{tabular}{|c|c|c|c|c|}
\hline & $\begin{array}{l}\text { Tier } 1 \\
\text { Measured in } \\
\text { Hidden Harvest } 1\end{array}$ & $\begin{array}{l}\text { Tier } 2 \\
\text { Data likely } \\
\text { available, in some } \\
\text { cases at national } \\
\text { or global level }\end{array}$ & $\begin{array}{l}\text { Tier } 3 \\
\text { Data scarce } \\
\text { and not likely } \\
\text { available }\end{array}$ & $\begin{array}{l}\text { No examples } \\
\text { found }\end{array}$ \\
\hline $\begin{array}{l}\text { Production and } \\
\text { utilization }\end{array}$ & $\begin{array}{l}\text { SSF catch by EEZ } \\
\text { SSF catch landed } \\
\text { value } \\
\text { Discards as a \% } \\
\text { of total catch }\end{array}$ & Use & & \\
\hline Employment & $\begin{array}{l}\text { SSF fishers } \\
\text { SSF post-harvest } \\
\text { jobs } \\
\text { Total workforce } \\
\text { Women as \% of } \\
\text { total workforce }\end{array}$ & $\begin{array}{l}\text { Indigenous or } \\
\text { ethnic workforce } \\
\text { Dependents } \\
\text { Disadvantaged } \\
\text { Women as \% of } \\
\text { fishers } \\
\text { Women as \% of } \\
\text { post-harvest }\end{array}$ & & \\
\hline Efficiency & $\begin{array}{l}\text { Catch per SS } \\
\text { fisher } \\
\text { SSF catch per ton } \\
\text { of fuel }\end{array}$ & CPUE & Catch emissions & Food waste \\
\hline $\begin{array}{l}\text { Economic } \\
\text { contribution }\end{array}$ & & & $\begin{array}{l}\text { Household } \\
\text { economy }\end{array}$ & \\
\hline $\begin{array}{l}\text { Food security } \\
\text { and nutrition }\end{array}$ & & $\begin{array}{l}\text { Protein } \\
\text { contribution* }\end{array}$ & & $\begin{array}{l}\text { Micronutrients } \\
\text { Nutrition } \\
\text { substitutes }\end{array}$ \\
\hline Trade & & $\begin{array}{l}\text { Exports } \\
\text { Consumption } \\
\text { markets }\end{array}$ & $\begin{array}{l}\text { Traceability } \\
\text { Subsidies }\end{array}$ & \\
\hline $\begin{array}{l}\text { Social } \\
\text { development }\end{array}$ & & $\begin{array}{l}\text { Age of SS fishers* } \\
\text { Prevalence of } \\
\text { STDs* } \\
\text { Access to health } \\
\text { services } \\
\text { Disaster loss } \\
\text { Disaster recovery } \\
\text { Land tenure } \\
\text { Social security } \\
\text { Urban proximity }\end{array}$ & $\begin{array}{l}\text { Access to clean } \\
\text { water } \\
\text { Offspring } \\
\text { employment } \\
\text { Substance abuse }\end{array}$ & \\
\hline $\begin{array}{l}\text { Environmental } \\
\text { impacts }\end{array}$ & & Stock assessment & & \\
\hline $\begin{array}{l}\text { Institutional } \\
\text { arrangements }\end{array}$ & & $\begin{array}{l}\text { Regulatory } \\
\text { structures* } \\
\text { Aid* } \\
\text { Governance } \\
\text { structure } \\
\text { Governance } \\
\text { participation }\end{array}$ & Accountability & $\begin{array}{l}\text { Non- } \\
\text { governmental } \\
\text { social services }\end{array}$ \\
\hline $\begin{array}{l}\text { Type of fishery } \\
\text { involved }\end{array}$ & & $\begin{array}{l}\text { Gear change } \\
\text { Gear ownership }\end{array}$ & & \\
\hline
\end{tabular}

*Likely available at the national or global level (all other second-tier indicators more likely available at smaller scales) 


\section{Workshop Session 3: How do we collect data and with whom?}

The following section, entitled "Discussion: Proposed approach and case studies", corresponds to the third session of the workshop.

\section{Discussion: Proposed approach and case studies}

\section{Proposed approach for carrying out a Hidden Harvest 2 study}

Although progress has been made in the development of global data sets of fisheries catch disaggregated by small- and large-scale, and assigned to locations, the majority of other indicators suggested that in order to provide a clearer picture of SSF activity and achieve the study's objective, they are only likely to be available at the national level or below, via a "case study approach". As with the first Hidden Harvest (Mills et al., 2011), a case study approach would not likely be able to prescribe a single methodology to all case study countries, but rather would assign study leaders to estimate the agreed indicators using the best available means in each country (e.g. national statistics, grey literature, interviews with local experts and focus group discussions). Data availability and reliability will of course vary significantly between countries, and as with the ISSF and scientific literature, measures of the indicators will not be available in each case.

\section{Proposed case studies}

Case studies are proposed at the scale of countries where feasible, and based on data availability and likely coverage of SSF activity rather than as a random or representative sample. More specifically, the three basic criteria for recommending case studies were:

1. Geographic coverage

2. Proportion of estimated SSF

3. Data availability

Case studies would be carried out by a study leader/organization in collaboration with national authorities and academic/research organizations, based on routine data collection, ad hoc surveys, project reports and expert knowledge, supplemented as needed by global data sets. Of course it will not be possible to measure all of the tier 2 and tier 3 indicators, but the review of existing information demonstrates that the knowledge and experience exists for collecting this data. Based on data availability, the number of case studies for at least the tier 1 indicators could potentially be expanded significantly from the first Hidden Harvest study, as follows:

\begin{tabular}{|c|c|c|}
\hline Country & In HH1? (yes/no) & Possible partners \\
\hline \multicolumn{3}{|l|}{ Asia } \\
\hline Bangladesh & Yes & SEAFDECNWorldFish \\
\hline Cambodia & Yes & WorldFish \\
\hline China & Yes & To be determined \\
\hline India & Yes & ICSF \\
\hline Indonesia & Yes & SEAFDEC \\
\hline Myanmar & Yes (partially) & WorldFish \\
\hline
\end{tabular}




\begin{tabular}{|c|c|c|}
\hline Country & In HH1? (yes/no) & Possible partners \\
\hline Philippines & Yes & SEAFDEC/WorldFish \\
\hline Thailand & Yes & SEAFDEC \\
\hline Viet Nam & Yes & SEAFDEC \\
\hline \multicolumn{3}{|l|}{ Africa } \\
\hline Cabo Verde & No & CSRP, INDP, World Bank \\
\hline Côte d'Ivoire & No & FCWC, World Bank \\
\hline Gambia & No & CSRP, World Bank \\
\hline Ghana & Yes & FCWC, World Bank \\
\hline Guinea-Bissau & No & CSRP, CIPA, World Bank \\
\hline Guinea & No & CSRP, World Bank \\
\hline Kenya & Yes & AU IBAR \\
\hline Liberia & No & FCWC, BNF, World Bank \\
\hline Madagascar & No & AU IBAR \\
\hline Mauritania & No & CSRP, IMROP, World Bank \\
\hline Morocco & No & AU IBAR \\
\hline Mozambique & Yes & AU IBAR \\
\hline Nigeria & Yes & AU IBAR \\
\hline Senegal & Yes & CSRP, CRODT, World Bank \\
\hline Sierra Leone & No & CSRP, IMBO, World Bank \\
\hline United Republic of Tanzania & Yes & AU IBAR, WFF \\
\hline Uganda & Yes & AU IBAR, WFF \\
\hline \multicolumn{3}{|l|}{ Latin America } \\
\hline Brazil & Yes & To be determined \\
\hline Chile & Yes & Universidad Pontificia \\
\hline Mexico & No & $\begin{array}{l}\text { Diagnóstico Nacional de } \\
\text { Organizaciones Pesqueras / } \\
\text { CONMECOOP }\end{array}$ \\
\hline Peru & No & TNC \\
\hline \multicolumn{3}{|l|}{ Small Island Developing States } \\
\hline Caribbean Islands & No & To be determined \\
\hline $\begin{array}{l}\text { Pacific Island Countries and } \\
\text { Territories }\end{array}$ & No & SPC, WorldFish \\
\hline \multicolumn{3}{|l|}{ Mediterranean } \\
\hline To be determined & No & GFCM \\
\hline
\end{tabular}

Proposal for Hidden Harvest 2 to recommendations for improved data collection systems

The Hidden Harvest 2 should take the opportunity to recommended improvements needed by data collection systems in order to enhance understanding and monitoring of SSF activity and socio-economic contributions, and to obviate the need for future global "one-off" studies. As suggested previously and written by numerous authors, there is an urgent need to enhance national statistical systems for monitoring SSF 
activity and socio-economic contributions, to enable them to meet the growing demand for data and information (Gee, 2015). Systems are needed because no single data collection instrument can collect all of the data needed to monitor the contributions of SSF to national development objectives and global targets such as the SDGs, and the consistency of their governance with the SSF Guidelines. For this reason, the Hidden Harvest 2 report should include recommendations to improve national data statistical systems, building upon past FAO efforts through the FishCode programme and strategies adopted by the Committee on Fisheries (COFI) for improving information on the status and trends in capture fisheries.

A key focus for SSF data collection would likely remain on sample-based surveys such as frame surveys of the number, characteristics and spatial distribution of vessels, gears, fishers, landing sites and fishing communities, or increasingly through vessel registers and license databases - though this will still likely miss subsistence fisheries where there is massive under-reporting, but perhaps could be corrected through questions included in census surveys or use of proxy indicators (de Graaf et al., 2011). Toward this end, the recent FAO Guidelines to Enhance Fisheries and Aquaculture Statistics through a Census Framework set out possible methods for establishing an integrated data collection and statistical system at least partially applicable to SSF (Gee, 2015). The Guidelines provide guidance on designing a questionnaire survey for fisheries and aquaculture that can be implemented within a census framework, i.e. within agricultural, population or rural censuses, but also specialized community and household surveys. Although using a census framework is costly, it was considered the approach that could most effectively and comprehensively illustrate the contribution made by small-scale operations (Gee, 2015).

\section{Three dimensions of data collection}

If the data is visualized in three dimensions - temporal coverage, content depth and population coverage - it becomes easier to envision how different types of data are generated (either actively or as a by-product) through different statistical instruments. Censuses and census-related surveys provide a one-time snapshot, and cover broad geographical areas and social segments with a wide range of contexts; their time interval is necessarily long, due to the substantial human and capital resources necessary to conduct censuses and census-related surveys. On the other hand, systematic and regular data collection through means such as annual statistical surveys offer time series information on the selected area, which is often located within selected geographical and social segments. These efforts can be balanced with the data that is generated through more detailed projects. Ad hoc data collection has an intermediate nature, and can provide the information required to fill the gaps ensuing from, and to draw links between, the results obtained from the census-type approach on one hand and a more focused regular data collection on the other.

Source: Gee, 2015 


\section{References}

Adhuri, D. S., Rachmawati, L., Sofyanto, H. \& Hamilton-Hart, N. 2016. Green market for small people: Markets and opportunities for upgrading in small-scale fisheries in Indonesia. Marine Policy, 63:198-205.

Aheto, D. W., Asare, N. K., Quaynor, B., Tenkorang, E. Y., Asare, C., \& Okyere, I. 2012. Profitability of Small-Scale Fisheries in Elmina, Ghana. Sustainability 4:2785-2794.

Aida Marin-Monroy, E. \& Ojeda-Ruiz de la Pena, M.A. 2016. The role of socioeconomic disaggregated indicators for fisheries management decisions: The case of Magdalena-Almejas Bay, BCS. Mexico. Fisheries Research 177:116-123.

Allison, E. 2011. Aquaculture, Fisheries, Poverty and Food Security. Working Paper 2011-65. Penang, WorldFish Center.

Arceo, H. O., Cazalet, B., Alino, L. Mangialajo, P.M. \& Francour, P. 2013. Moving beyond a top-down fisheries management approach in the northwestern Mediterranean: Some lessons from the Philippines. Marine Policy 39:29-42.

Baigun, C., Minotti, P. \& Oldani, N. 2013. Assessment of sabalo (Prochilodus lineatus) fisheries in the lower Parana River basin (Argentina) based on hydrological, biological, and fishery indicators. Neotropical Ichthyology 11:199210.

Barnes-Mauthe, M., Oleson, C.L.L. \& Zafindrasilivonona, B. 2013. The total economic value of small-scale fisheries with a characterization of post-landing trends: an application in Madagascar with global relevance. Fisheries Research, 147(2013): 175-185.

Bartley, D.M., De Graaf, G.J., ValboøJørgensen, J. and Marmulla, G., 2015. Inland capture fisheries: status and data issues. Fisheries Management and Ecology, 22(1):71-77.

Basurto, X., Bennett, A., Hudson Weaver, A., Rodriguez-Van Dyck, S. \& Aceves-Bueno, J.-S. 2013. Cooperative and Noncooperative Strategies for Small-scale Fisheries' Self-governance in the Globalization Era: Implications for Conservation. Ecology and Society 18.

Basurto, X., Cinti, A., Bourillon, L., Rojo, M., Torre, J. \& Hudson Weaver, A. 2012. The Emergence of Access Controls in Small-Scale Fishing Commons: Av Comparative Analysis of Individual Licenses and Common Property-Rights in Two Mexican Communities. Human Ecology 40:597-609. 
Basurto, X., Virdin, J., Smith, H. \& R. Juskus. 2017. Strengthening Governance of Small-Scale Fisheries: An Initial Assessment of Theory and Practice. Oak Foundation: www.oakfnd.org/environment.

Basurto, X., Virdin, J., Smith, H. \& Juskus, R. 2017. Strengthening Governance of Small-Scale Fisheries: An Initial Assessment of the Theory and Practice. Oak Foundation (available at www.oakfnd.org/environment).

Bazigos, G.P. 1974. Applied fishery statistics. FAO Fisheries Technical Papers (FAO).

Bènè, C. 2006. Small-scale fisheries: assessing their contribution to rural liveliboods in developing countries. FAO Fisheries Circular 1008. Rome, FAO.

Begossi, A., Salivonchyk, S.V., Hanazaki, N., Martins, I.M. \& Bueloni, F. 2012. Fishers (Paraty, RJ) and fish manipulation time: a variable associated to the choice for consumption and sale. Brazilian Journal of Biology 72:973-975.

Beitl, C. M. 2014. Navigating Over Space and Time: Fishing Effort Allocation and the Development of Customary Norms in an Open-Access Mangrove Estuary in Ecuador. Human Ecology 42:395-411.

Bell, J.D., Allain, V., Allison, E.H., Andréfouët, S., Andrew, N.L., Batty, M.J., Blanc, M., Dambacher, J.M., Hampton, J., Hanich, Q. \& Harley, S. 2015. Diversifying the use of tuna to improve food security and public health in Pacific Island countries and territories. Marine Policy, 51:584-591.

Bene, C., Barange, M., Subasinghe, R., Pinstrup-Andersen, P., Merino, G., Hemre, G.-I. \& Williams, M. 2015. Feeding 9 billion by 2050-Putting fish back on the menu. Food Security 7:261-274.

Bennett, N. J., Dearden, P., Murray, G. \& Kadfak, A. 2014. The capacity to adapt?: communities in a changing climate, environment, and economy on the northern Andaman coast of Thailand. Ecology and Society 19.

Bos, A. R., \& Gumanao, G.S. 2012. The lunar cycle determines availability of coralreef fishes at fish markets. Journal of Fish Biology 81:2074-2079.

Broch, H. B. 2013. Social resilience - local responses to changes in social and natural environments. Maritime Studies 12:1-17.

Berkes, F., Mahon, R., McConney, P., Pollnac, R. \& Pomeroy, R. 2001. Managing Small-Scale Fisheries: Alternative Directions and Methods. Ottawa, IDRC.

Caddy, J.F. \& Bazigos, G.P. 1985. Practical guidelines for statistical monitoring of fisheries in manpower limited situations. FAO. 
Carr, L. M. \& Heyman, W.D. 2012. “It's About Seeing What's Actually Out There": Quantifying fishers' ecological knowledge and biases in a smallscale commercial fishery as a path toward co-management. Ocean E Coastal Management 69:118-132.

Cinner, J. E. \& McClanahan, T.R. 2015. A sea change on the African coast? Preliminary social and ecological outcomes of a governance transformation in Kenyan fisheries. Global Environmental Change-Human and Policy Dimensions 30:133-139.

Chuenpagdee, R., Liguori, L., Palomares, M.L.D. \& Pauly, D. 2006. Bottom-Up, Global Estimates of Small-Scale Marine Fisheries Catches. Fisheries Center Research Report 14(8). Vancouver, University of British Columbia.

Coetzee, H. C., Nell, W., van Eeden, E. S. \& de Crom, E. P. 2015. Artisanal Fisheries in the Ndumo Area of the Lower Phongolo River Floodplain, South Africa. Koedoe 57.

Damasio, L. d. M. A., Lopes, P. F. M., Guariento, R. D. \& Carvalho, A. R. 2015. Matching Fishers' Knowledge and Landing Data to Overcome Data Missing in Small-Scale Fisheries. Plos One 10:e0133122-e0133122.

de Graaf, G., Grainger, R., Westlund, L., Willmann, R., Mills, D.J., Kelleher, K. \& Koranteng, K. 2011. The status of routine fisheries data collection in Southeast Asia, Central America, South Pacific and West Africa, with special reference to small scale fisheries. ICES Journal of Marine Science, 68: 1743-1750.

de Graaf, G. \& Garibaldi, L. 2014. The Value of African Fisheries. FAO Fisheries and Aquaculture Circular No. 1093. Rome, FAO.

Dresdner, J., Chavez, C. \& Barriga, O. 2015. Compliance in Artisanal Fisheries: Do Morality, Legitimacy, and peer Effects Matter? Marine Resource Economics 30:349-370.

Dyck, A.J. \& Sumaila, U.R. 2010. Economic impact of ocean fish populations in the global fishery. Journal of Bioeconomics, 12(3):227-243.

Ernst, B., Chamorro, J., Manriquez, P., Orensanz, J. M. L., Parma, A. M. , Porobic, J. \& Roman, C. 2013. Sustainability of the Juan Fernandez lobster fishery (Chile) and the perils of generic science-based prescriptions. Global Environmental Change-Human and Policy Dimensions 23:1381-1392.

Fabinyi, M., Pido, M., Marie Ponce de Leon, E., Aileen De las Alas, M., Buenconsejo, J., Uyami-Bitara, A., Harani, B. \& Caceres, J. 2014. Fisheries Trade and Social Development in the Philippine-Malaysia Maritime Border Zone. Development Policy Review 32:715-732.

FAO. 1990-2017. CWP Handbook of Fishery Statistical Standards. Section C: NATIONALITY. CWP Data Collection. In: FAO Fisheries and Aquaculture 
Department [online]. Available at www.fao.org/fishery/cwp/handbook/C/en.

FAO. 2008-2016. Small-scale fisheries - Web Site. People and communities. FI Institutional Websites. In: FAO Fisheries and Aquaculture Department [online]. Rome. Updated. [Cited 30 December 2016]. www.fao.org/fishery/ssf/people/en

FAO. 2008-2017. Fish harvesting. FI Institutional Websites. In: FAO Fisheries and Aquaculture Department [online]. Rome. Updated 24 September 2012. [Cited 3 January 2017]. www.fao.org/fishery/topic/16611/en

FAO. 2003. Report of the Second Session of the Working Party on Small-Scale Fisheries, 18-21 November 2003. FAO Advisory Committee on Fisheries Research (ACFR). Rome.

FAO. 2008. Food Balance Sheets: A Handbook. Rome (available at www.fao.org/3/ax9892e.pdf).

FAO. 2011. Global food losses and food waste. Rome.

FAO. 2015. Voluntary Guidelines for Securing Sustainable Small-Scale Fisheries in the Context of Food Security and Poverty Eradication. Rome.

FAO. 2016a. The State of World Fisheries and Aquaculture. Rome.

FAO. 2016b. Definition of Capture Fishery. FAO Fisheries Glossary. Entry 85841. www.fao.org/faoterm/en/?defaultCollId=21

FAO. 2016c. Definition of Small-Scale Fishery. FAO Fisheries Glossary. Entry 98107. www.fao.org/faoterm/en/?defaultCollId $=21$

FAO. 2016d. FAO/INFOODS Global Food Composition Database for Fish and Shellfish Version 1.0 - uFish1.0. Rome.

FAO. 2017. Fishery and Aquaculture Statistics. Global capture production 1950-2015 (FishstatJ). In: FAO Fisheries and Aquaculture Department [online]. Rome. Updated 2017. Available at www.fao.org/fishery/statistics/software/fishstatj/en.

FAO, WorldFish Center \& World Bank. 2008. Small-scale capture fisheries: A global overview with emphasis on developing countries. Big Numbers Project, Preliminary Report: Big Numbers Project. Washington, DC, World Bank.

Fargier, L., Hartmann, H. J. \& Molina-Urena, H. 2014. "Marine Areas of Responsible Fishing”: A Path Toward Small-Scale Fisheries Co-Management in Costa Rica? Perspectives from Golfo Dulce. Pages 155-179 in F. Amezcua and B. Bellgraph, editors. Fisheries Management of Mexican and Central American Estuaries.

Fernandes, R. M. 2012. Job satisfaction in the marine and estuarine fisheries of Guinea-Bissau. Social Indicators Research 109:11-23. 
Fernandez-Boan, M., Fernandez, L. \& Freire, J. 2012. History and management strategies of the sea urchin Paracentrotus lividus fishery in Galicia (NW Spain). Ocean E Coastal Management 69:265-272.

Freon, P., Avadi, A., Marin Soto, W. \& Negron, R. 2014. Environmentally extended comparison table of large-versus small- and medium-scale fisheries: the case of the Peruvian anchoveta fleet. Canadian Journal of Fisheries and Aquatic Sciences 71:1459-1474.

Fishing for a Future. 2016. Getting to Eden: building an ideal future for the global fish food system through collective action (available at www.fishingfuture.org).

Garcia, S.M. 2009. Rising to Depletion? Towards a dialogue on the state of national marine fisheries. Prepared for the Global Program on Fisheries (PROFISH). Preliminary Report, April 2009 (Version 2). Agriculture and Rural Development Department, The World Bank. Washington, DC, World Bank (available at http://siteresources.worldbank.org/EXTARD/Resources/336681-1224775570533/ RisingtoDepletion.pdf).

Gee, J. 2015. Guidelines to Enhance Fisheries and Aquaculture Statistics through a Census Framework. Rome, FAO.

Gilbert, B. \& Yeo, B. H. 2014. Technological Change and Managerial Ability: Evidence from a Malaysian Artisanal Fishery. Land Economics 90:352-371.

Guyader, O., Berthou, P., Koutsikopoulos, C., Alban, F., Demaneche, S., Gaspar, M.B., Eschbaum, R., Fahy, E., Tully, O., Reynal, L. \& Curtil, O. 2013. Small scale fisheries in Europe: A comparative analysis based on a selection of case studies. Fisheries Research, 140:1-13.

Harper, S., Grubb, C., Stiles, M. \& Sumaila, U.R. 2017. Contributions by women to fisheries economies: insights from five maritime countries. Coastal Management, 45(2): 1-16.

Hill, N. A. O., Rowcliffe, J. M., Koldewey, H. J. \& Milner-Gulland, E. J. 2012. The Interaction between Seaweed Farming as an Alternative Occupation and Fisher Numbers in the Central Philippines. Conservation Biology 26:324-334.

HLPE. 2014. Sustainable fisheries and aquaculture for food security and nutrition. A report by the High Level Panel of Experts on Food Security and Nutrition of the Committee on World Food Security, Rome 2014.

Islam, G. M. N., Yew, T. S. \& Viswanathan, K. K. 2014. Poverty and livelihood impacts of community based fisheries management in Bangladesh. Ocean $\mathcal{E}$ Coastal Management 96:123-129. 
Kalikoski, D. C. \& Vasconcellos, M. 2012. Case study of the technical, socioeconomic and environmental conditions of small-scale fisheries in the estuary of Patos Lagoon, Brazil: a methodology for assessment. FAO Fisheries and Aquaculture Circular 1075:1-III.

Kolding, J., van Zwieten, P.1., Martin, F. \& Poulain, F. 2016. Fisheries in the drylands of sub-Sabaran Africa - "Fish come with the rains". Building resilience for fisheries-dependent liveliboods to enhance food security and nutrition in the drylands. FAO Fisheries and Aquaculture Circular No. 1118. Rome, FAO.

Laksanawimol, P., Petpiroon, S. \& Damrongphol, P. 2013. Trade of Seahorses, Hippocampus spp. (Actinopterygii: Syngnathiformes: Sygnathiformes: Sygnathidae), on the East Coast of the Gulf of Thailand. Acta Ichthyologica Et Piscatoria 73:229-235.

Leticia Bravo-Olivas, M., Maria Chavez-Dagostino, R., Malcolm, C. D. \& Espinoza-Sanchez, R. 2015. Notes on the Quality of Life of Artisanal SmallScale Fishermen along the Pacific Coast of Jalisco, Mexico. Sustainability 7:6046-6068.

Le Xuan, S. 2012. Job Satisfaction in the Shrimp Trawl Fisheries of Vietnam. Social Indicators Research 109:39-51.

Marin, A., Bodin, O., Gelcich, S. \&Crona, B. 2015. Social capital in post-disaster recovery trajectories: Insights from a longitudinal study of tsunami-impacted small-scale fisher organizations in Chile. Global Environmental ChangeHuman and Policy Dimensions 35:450-462.

Melnychuk, M.C., Clavelle, T., Owashi, B. \& Strauss, K. 2016. Reconstruction of global ex-vessel prices of fished species. ICES Journal of Marine Science, doi: 10.1093/icesjMs./fsw169.

Mills, D.J., Westlund, L., de Graaf, G., Kura, Y., Willmann, R. \& Kelleher, K. 2011. Under-reported and undervalued: small-scale fisheries in the developing world. In N.L. Andrew \& R. Pomeroy, eds. Small-scale fisheries management: frameworks and approaches for the developing world, pp. 1-15. Wallingford, UK, CABI.

Misund, O.A., Kolding, J. \& Fréon, P. 2002. Fish capture devices in industrial and artisanal fisheries and their influence on management. Handbook of fish biology and fisheries, 2:13-36.

Muallil, R. N., Cleland, D. \& Alino, P.M. 2013. Socioeconomic factors associated with fishing pressure in small-scale fisheries along the West Philippine Sea biogeographic region. Ocean E Coastal Management 82:27-33. 
Muller, J. D. S., Falcao, I. R., Couto, M. C. B. M. ,Viana, W. d. S. ,Alves, I. B. , Viola, D. N., Woods, C. G. \& Rego, R. F. 2016. Health-Related Quality of Life among Artisanal Fisherwomen/Shellfish Gatherers: Lower than the General Population. International journal of environmental research and public health 13 .

Munas, M. \& Lokuge, G. 2016. Shocks and coping strategies of coastal communities in war-conflict-affected areas of the north and east of Sri Lanka. Regional Environmental Change 16:289-299.

Needham, S. \& Funge-Smith, S. 2015. The consumption of fish and fish products in the Asia Pacific region based on household surveys. RAP Publication 2015/12. Rome, FAO.

OECD. 2016. The Ocean Economy in 2030. Paris.

Paudel, S., Levesque, J. C., Saavedra, C., Pita, C. \& Pal, P. 2016. Characterization of the artisanal fishing communities in Nepal and potential implications for the conservation and management of Ganges River Dolphin (Platanista gangetica gangetica). Peerj 4.

Percin, F., Akyol, O., Davas, A. \& Saygi, H. 2012. Occupational health of Turkish Aegean small-scale fishermen. Occupational Medicine-Oxford 62:148-151.

Perret, S. R. \& Yuerlita. 2014. Adapting to declining fish resources: the differentiation of livelihood systems and fishing strategies in Singkarak Lake's fishing community, West Sumatra. Regional Environmental Change 14:12031214.

Pinello, D., Gee, J. \& Dimech, M. 2017. Handbook for fisheries socio-economic sample survey: principles and practice. FAO Fisheries and Aquaculture Technical Paper No. 613. Rome, FAO.

Pinto, M. F., Mourao, J. S. \& Nobrega Alves, R. R. 2015. Use of ichthyofauna by artisanal fishermen at two protected areas along the coast of Northeast Brazil. Journal of Ethnobiology and Ethnomedicine 11.

Pollnac, R. B. \& Kotowicz, D. 2012. Post Tsunami Job Satisfaction Among the Fishers of Na Pru Village, on the Andaman Sea Coast of Thailand. Social Indicators Research 109:67-80.

Purcell, S. W., Mercier, A.,Conand, C., Hamel, J.-F. , Veronica Toral-Granda, M., Lovatelli, A. \& Uthicke. S. 2013. Sea cucumber fisheries: global analysis of stocks, management measures and drivers of overfishing. Fish and Fisheries 14:34-59.

Ratner, B. D. \& Allison, E.H. 2012. Wealth, Rights, and Resilience: An Agenda for Governance Reform in Small-scale Fisheries. Development Policy Review 30:371-398. 
Robles-Zavala, E. 2014. Coastal livelihoods, poverty and well-being in Mexico. A case study of institutional and social constraints. Journal of Coastal Conservation 18:431-448.

Salas, S., Chuenpagdee, R., Charles, A.T. \& Seijo, J.C. eds. 2011. Coastal fisheries of Latin America and the Caribbean. Food and Agriculture Organization of the United Nations. Rome.

Srivastava, M. \& Tsuji, S. 2016. Status and Recent Developments in Fisheries and Aquaculture Statistics. Asia Pacific Commission on Agricultural Statistics. Twenty-Sixth Session, 15-19 February 2016, Bhutan. Rome, FAO (available at www.fao.org/fileadmin/templates/ess/documents/apcas26/presentations/ APCAS-16-6.3.1_-_FAO_-_Status_and_recent_development_of_fisheries_and_ aquaculture_statistics.pdf).

Sumaila, U.R., Marsden, A.D., Watson, R., \& Pauly, D. 2007. A global ex-vessel fish price database: construction and applications. Journal of Bioeconomics, 9(1): 39-51.

Swartz, W., Sumaila, R. \& Watson, R. 2013. Global ex-vessel fish price database revisited: a new approach for estimating 'missing' prices. Environmental and Resource Economics, 56(4): 467-480.

Teh, L.S.L., Teh, L.C.L. \& Sumaila, U.R. 2011. Quantifying the overlooked socioeconomic contribution of small-scale fisheries in Sabah, Malaysia. Fisheries Research, 110(3): 450-458.

Tesfamichael, D. \& Mohamud, S. 2016. Eritrea. In The Red Sea Ecosystem and Fisheries, 49-63. Springer Netherlands.

Tesfaye, G. \& Wolff, M. 2015. Stock assessment of fishery target species in Lake Koka, Ethiopia. Revista De Biologia Tropical 63:755-770.

Thorpe, A., Pouw, N., Baio, A., Sandi, R., Ndomahina, E.T. \& Lebbie, T. 2014. "Fishing Na Everybody Business": Women's Work and Gender Relations in Sierra Leone's Fisheries. Feminist Economics 20:53-77.

Thomson, D. 1980. "Conflict within the Fishing Industry." ICLARM Newsletter, 3:3-4.

Ticheler, H.J., Kolding, J. \& Chanda, B. 1998. Participation of local fishermen in scientific fisheries data collection: a case study from the Bangweulu Swamps, Zambia. Fisheries Management and Ecology, 5(1):81-92.

Tran Thi Phung, H. \& van Dijk, H. 2013. Fishery livelihoods and (non-)compliance with fishery regulations-A case study in Ca Mau Province, Mekong Delta, Viet Nam. Marine Policy 38:417-427. 
Trimble, M., de Araujo, L. G. \& Seixas, C. S. 2014. One party does not tango! Fishers' non-participation as a barrier to co-management in Paraty, Brazil. Ocean E Coastal Management 92:9-18.

United Nations General Assembly. 2015. Resolution adopted by the General Assembly on 25 September 2015, Transforming our world: the 2030 agenda for sustainable development. A/Res/70/1. New York, USA (available at www. un.org/ga/search/view_doc.asp?symbol=A/RES/70/1\&Lang=E).

Vieira, N. C., de Moraes, S. C. \& Pimentel Nunes, Z. M. 2013. A Study of Fishing and Educational Level of Young Fishers on the Bonifacio village, BRAGANÇA, PARÁ, NORTHERN COAST OF BRAZIL. Boletim Do Instituto De Pesca 39:195-204.

Watson, R., Kitchingman, A., Gelchun, A. \& Pauly, D. 2004. Mapping global fisheries: sharpening our focus. Fish and Fisheries, 5: 168-177.

Watson, R. 2017. A database of global marine commercial, small-scale, illegal and unreported fisheries catch: 1950-2014. Scientific Data, 4 (available at www. nature.com/articles/sdata201739\#f1).

Wilson, M., Pavlowich, T. \& Cox, M. 2016. Studying common-pool resources over time: A longitudinal case study of the Buen Hombre fishery in the Dominican Republic. Ambio 45:215-229.

World Bank. 2009. Project Appraisal Document: West Africa Regional Fisheries Program. Washington, DC.

World Bank, FAO \& WorldFish Center. 2012. Hidden Harvest: The Global Contribution of Capture Fisheries. Report No. 66469-GLB. Washington, DC, World Bank.

World Food Summit. 1996. Rome Declaration on World Food Security.

Zeller, D. \& Pauly, D. 2016. Marine fisheries catch reconstruction: definitions, sources, methodology and challenges. In D. Pauly \& D. Zeller, eds. Global atlas of marine fisheries: ecosystem impacts and analysis. Washington, DC, Island Press. 


\section{Appendix 1. Summary of measures estimated in Hidden Harvest}

Global profile of small- and large-scale fisheries (\% in developing countries)

\begin{tabular}{|c|c|c|c|c|c|c|c|}
\hline & \multicolumn{3}{|c|}{ Small-scale fisheries } & \multicolumn{3}{|c|}{ Large-scale fisheries } & \multirow{2}{*}{ Total } \\
\hline & Marine & Inland & Total & Marine & Inland & Total & \\
\hline \multicolumn{8}{|c|}{ Production and utilization } \\
\hline $\begin{array}{l}\text { Total annual } \\
\text { catch (million } \\
\text { tons) }\end{array}$ & $\begin{array}{r}34 \\
(82 \%)\end{array}$ & $\begin{array}{r}14 \\
(93 \%)\end{array}$ & $\begin{array}{r}48 \\
(85 \%)\end{array}$ & $\begin{array}{r}56 \\
(61 \%)\end{array}$ & $1(50 \%)$ & $\begin{array}{r}57 \\
(61 \%)\end{array}$ & $\begin{array}{r}105 \\
(72 \%)\end{array}$ \\
\hline $\begin{array}{l}\text { Value (US\$ } \\
\text { billions) }\end{array}$ & $\begin{array}{r}37 \\
(76 \%)\end{array}$ & $9(89 \%)$ & $\begin{array}{r}46 \\
(80 \%)\end{array}$ & $\begin{array}{r}49 \\
(71 \%)\end{array}$ & $0(0 \%)$ & $\begin{array}{r}50 \\
(71 \%)\end{array}$ & $\begin{array}{r}96 \\
(75 \%)\end{array}$ \\
\hline $\begin{array}{l}\text { Discards } \\
\text { (\% of total } \\
\text { catch)* }\end{array}$ & 4 & 0 & 3 & 13 & 3 & 13 & 8 \\
\hline \multicolumn{8}{|c|}{ Employment (full-time and part-time) } \\
\hline $\begin{array}{l}\text { Number } \\
\text { of fishers } \\
\text { (millions) }\end{array}$ & $\begin{array}{r}14 \\
(93 \%)\end{array}$ & $\begin{array}{r}18 \\
(100 \%)\end{array}$ & $\begin{array}{r}32 \\
(97 \%)\end{array}$ & $\begin{array}{r}2 \\
(100 \%)\end{array}$ & $\begin{array}{r}1 \\
(100 \%)\end{array}$ & $\begin{array}{r}3 \\
(100 \%)\end{array}$ & $\begin{array}{r}35 \\
(97 \%)\end{array}$ \\
\hline $\begin{array}{l}\text { Number of } \\
\text { post-harvest } \\
\text { jobs (millions) }\end{array}$ & $\begin{array}{r}38 \\
(97 \%)\end{array}$ & $\begin{array}{r}38 \\
(100 \%)\end{array}$ & $\begin{array}{r}76 \\
(99 \%)\end{array}$ & $\begin{array}{r}7 \\
(100 \%)\end{array}$ & $\begin{array}{r}0.5 \\
(100 \%)\end{array}$ & $\begin{array}{r}8 \\
(100 \%)\end{array}$ & $\begin{array}{r}84 \\
(98 \%)\end{array}$ \\
\hline $\begin{array}{l}\text { Total } \\
\text { workforce } \\
\text { (millions) }\end{array}$ & $\begin{array}{r}52 \\
(96 \%)\end{array}$ & $\begin{array}{r}56 \\
(100 \%)\end{array}$ & $\begin{array}{r}108 \\
(98 \%)\end{array}$ & $\begin{array}{r}9 \\
(100 \%)\end{array}$ & $\begin{array}{r}2 \\
(100 \%)\end{array}$ & $\begin{array}{r}11 \\
(100 \%)\end{array}$ & $\begin{array}{r}119 \\
(97 \%)\end{array}$ \\
\hline $\begin{array}{l}\text { Women } \\
\text { in total } \\
\text { workforce } \\
(\%)\end{array}$ & 36 & 54 & 46 & 64 & 28 & 60 & 47 \\
\hline \multicolumn{8}{|l|}{ Efficiency } \\
\hline $\begin{array}{l}\text { Catch per } \\
\text { fisher (tons) }\end{array}$ & $\begin{array}{r}2.5 \\
(84 \%)\end{array}$ & $\begin{array}{r}0.8 \\
(88 \%)\end{array}$ & $\begin{array}{r}1.5 \\
(87 \%)\end{array}$ & $\begin{array}{r}25.7 \\
(71 \%)\end{array}$ & $\begin{array}{r}0.6 \\
(100 \%)\end{array}$ & $\begin{array}{r}18.3 \\
(73 \%)\end{array}$ & $\begin{array}{r}3.0 \\
(73 \%)\end{array}$ \\
\hline $\begin{array}{l}\text { Catch per ton } \\
\text { of fuel (tons) }\end{array}$ & $1-3$ & $\mathrm{n} / \mathrm{a}$ & $\mathrm{n} / \mathrm{a}$ & $1-4$ & $\mathrm{n} / \mathrm{a}$ & $\mathrm{n} / \mathrm{a}$ & $\mathrm{n} / \mathrm{a}$ \\
\hline
\end{tabular}




\section{Appendix 2. Synthesis of measures submitted to TBTI's ISSF since 2010}

TBTI's ISSF ${ }^{33}$ includes 165 SSF profiles crowdsourced from researchers all over the world, completing profiles using a standard set of indicators to describe the characteristics of SSF at a given spatial scale, often from fieldwork or grey literature. An inventory was conducted of the profiles entered from 2010 onwards in order to synthesize case studies collected since the first Hidden Harvest. SSF profiles were included in the inventory if: (i) completed in 2010 or after, (ii) data was entered for at least half of the indicators, and (iii) the SSF profiled was not in a high-income country. This search protocol yielded a total of 49 SSF profiles from 24 countries, representing at least 67353 households (based on those profiles where the total number of households in the location was recorded). Roughly two-thirds of these SSF profiles described fisheries at a substate spatial scale equivalent to a village or group of villages.

\section{Non-High Income Countries with SSF Profiles since 2010*}

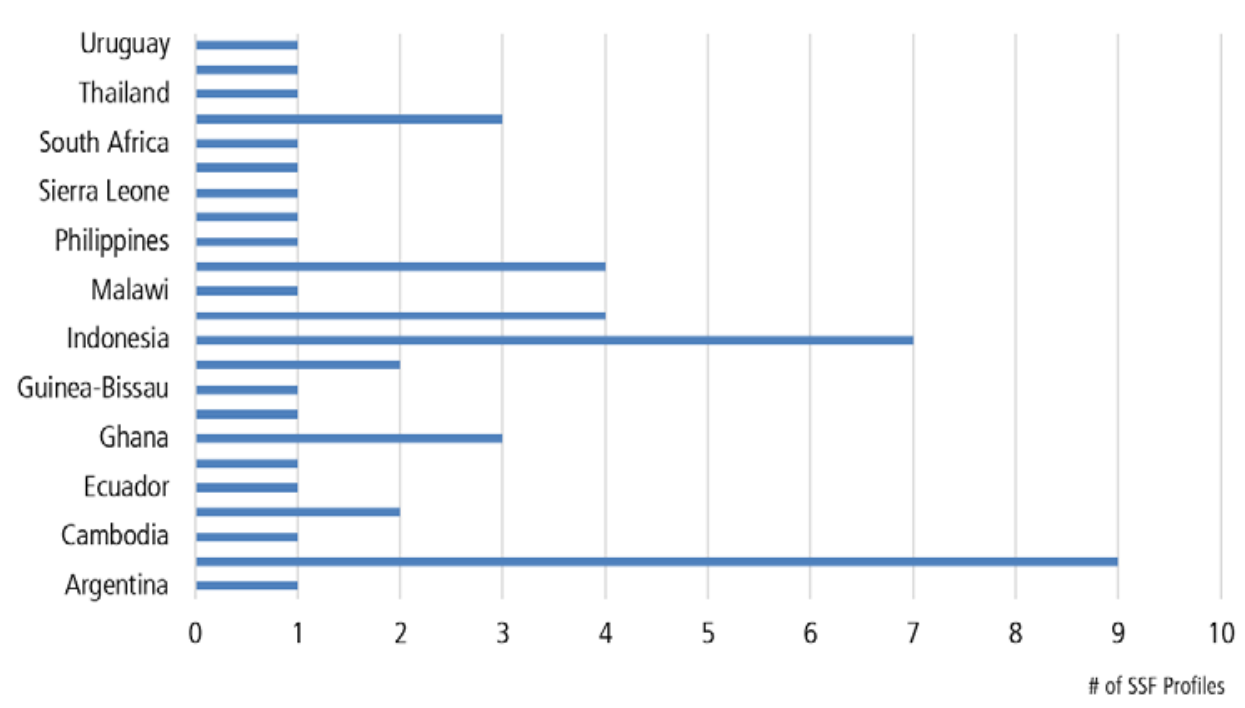

*SSF Profiles with less than half of indicators measured are not included.

Across these SSF profiles $(n=49)$, the number of measures per each of the indicators in the standard set was recorded by spatial scale: substate, state or national. The term "substate" refers to the smallest spatial scale: a village, or group of villages, or in some cases a district. The term "state" refers to the largest political unit within a country, e.g. a state or province within a country. 


\section{Number of SSF Profiles Recording Data for Each Indicator, by Spatial Scale}

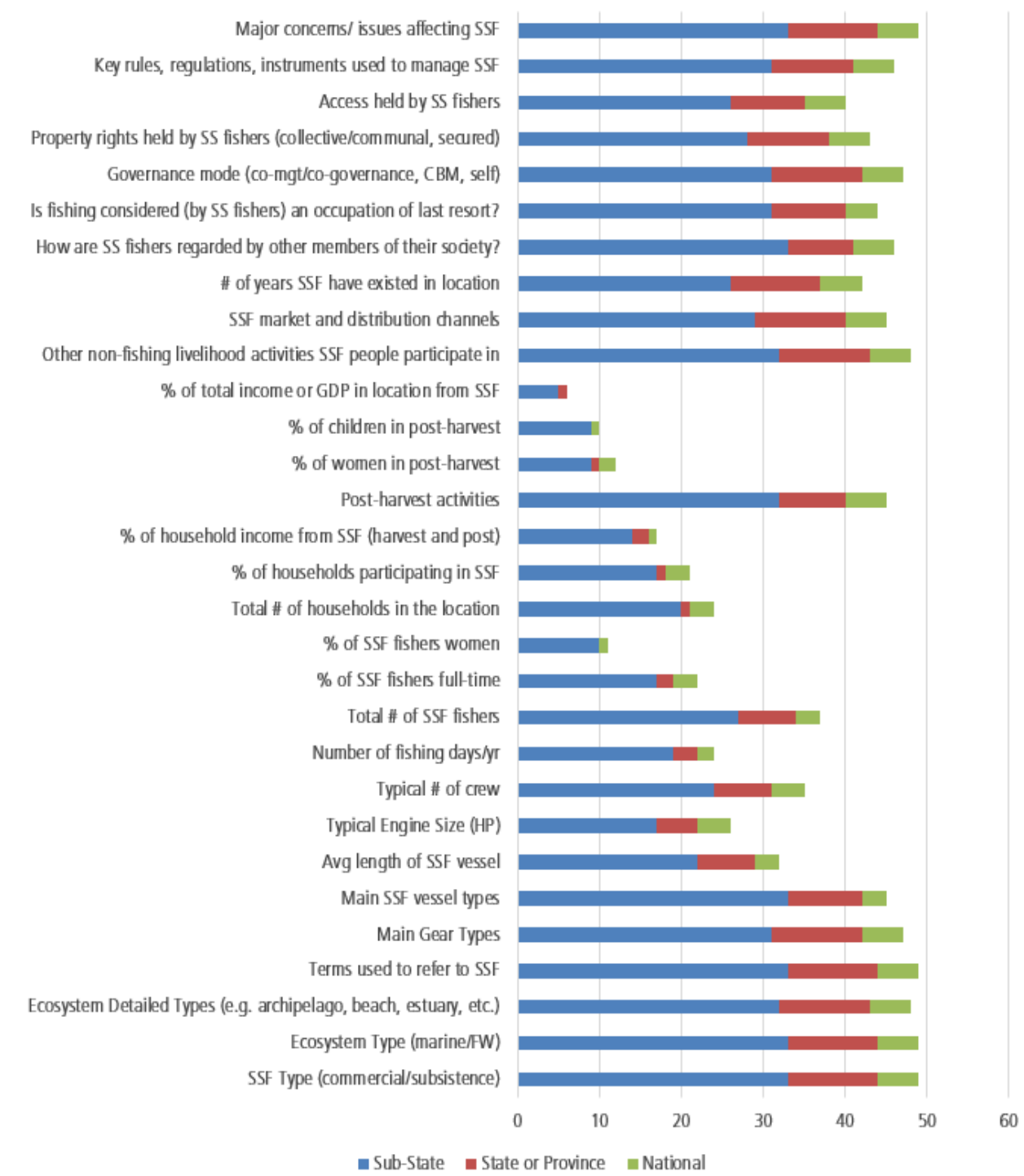




\section{Appendix 3. Full list of indicators searched in the scientific literature}

The table below provides the full list of SSF indicators (i.e. variables, concepts) searched in the scientific literature for the period of 2012-2016. These indicators were considered additional to those estimated in the first Hidden Harvest study.

\begin{tabular}{|c|c|c|}
\hline Indicator name & Indicator description & Search terms \\
\hline \multicolumn{3}{|c|}{ Production and utilization } \\
\hline Use & $\begin{array}{l}\text { End use of catch; for human consumption vs } \\
\text { non-consumptive uses (reduced to meals/oil, } \\
\text { aquarium trade) }\end{array}$ & $\begin{array}{l}\text { Consumption, fish oil, } \\
\text { fishmeal, aquarium }\end{array}$ \\
\hline \multicolumn{3}{|c|}{ Employment (full-time and part-time) } \\
\hline $\begin{array}{l}\text { Indigenous or ethnic } \\
\text { workforce }\end{array}$ & $\begin{array}{l}\text { Indigenous persons or ethnic minorities } \\
\text { represented in the fishing workforce }(\%)\end{array}$ & $\begin{array}{l}\text { Indigenous, ethnic group, } \\
\text { ethnic AND workforce }\end{array}$ \\
\hline Dependents & Fisher household dependents & Dependents, household size \\
\hline Disadvantaged & $\begin{array}{l}\text { Employment of disadvantaged segments } \\
\text { of the population (elderly, widowed, } \\
\text { orphaned, disabled) }\end{array}$ & $\begin{array}{l}\text { Elderly, orphan, widow, } \\
\text { disabled }\end{array}$ \\
\hline Labour exploitation & $\begin{array}{l}\text { "Labour exploitation" (average hours } \\
\text { worked compared with the legal maximum) }\end{array}$ & $\begin{array}{l}\text { Hours worked, labour } \\
\text { exploitation }\end{array}$ \\
\hline \multicolumn{3}{|l|}{ Efficiency } \\
\hline CPUE & Catch per unit effort & CPUE \\
\hline Discards & $\begin{array}{l}\text { Measuring discards in a fishery. Discards of } \\
\text { undesirable species, or regulatory discards } \\
\text { (required to discard based on size, species, } \\
\text { etc.) }\end{array}$ & Discards, discard \\
\hline Food waste & $\begin{array}{l}\text { Food waste (food loss) that occurs on land. } \\
\text { Could occur in the market, processing, end } \\
\text { user, etc. }\end{array}$ & Food waste, food loss \\
\hline Subsidy & Subsidizing fishing or subsidies to not fish & Subsidy, subsidies, subsidize \\
\hline \multicolumn{3}{|l|}{ Economic contribution } \\
\hline Household economy & $\begin{array}{l}\text { Economic contribution to household } \\
\text { economy (\% related to other incomes) }\end{array}$ & Household economy \\
\hline \multicolumn{3}{|c|}{ Food security and nutrition } \\
\hline Protein contribution & $\begin{array}{l}\text { Contribution to animal protein intake in } \\
\text { developing coastal and island states (\% } \\
\text { animal protein from fish) }\end{array}$ & $\begin{array}{l}\text { Protein intake, protein AND } \\
\text { nutrition }\end{array}$ \\
\hline Micronutrients & $\begin{array}{l}\text { Contribution to nutrition in developing } \\
\text { coastal and island states ( } \% \text { vitamin A, zinc } \\
\text { and iron derived from fish) }\end{array}$ & Micronutrients, vitamin \\
\hline Nutrition substitute & $\begin{array}{l}\text { Nutrition replacement costs (cost of next } \\
\text { cheapest alternative source of protein, } \\
\text { vitamin A, zinc and iron) }\end{array}$ & $\begin{array}{l}\text { Protein substitute, alternative } \\
\text { protein, vitamin substitute, } \\
\text { alternative vitamin }\end{array}$ \\
\hline \multicolumn{3}{|l|}{ Trade } \\
\hline Exports & $\begin{array}{l}\text { Catch exported }(\%) \text { at the smallest political } \\
\text { scale possible }\end{array}$ & Export, exports \\
\hline Consumption market & $\begin{array}{l}\text { Consumption market (local, non-local, size), } \\
\text { end consumer }\end{array}$ & $\begin{array}{l}\text { Consumption AND market, } \\
\text { market AND consumption, } \\
\text { consumer }\end{array}$ \\
\hline Traceability & $\begin{array}{l}\text { Traceability of market/value/ } \\
\text { commercialization chain (\# of } \\
\text { intermediaries before reaching final } \\
\text { consumer, etc.) }\end{array}$ & Traceability, value chain \\
\hline \multicolumn{3}{|l|}{ Social development } \\
\hline Literacy & $\begin{array}{l}\text { Literacy ( } \% \text { workforce) at the smallest } \\
\text { political scale possible }\end{array}$ & Literacy \\
\hline Government health & $\begin{array}{l}\text { Access to health services (hospitals, } \\
\text { clinics, medication, vaccines) provided by } \\
\text { government institutions }\end{array}$ & Health services, health care \\
\hline
\end{tabular}




\begin{tabular}{|c|c|c|}
\hline Indicator name & Indicator description & Search terms \\
\hline Social security & $\begin{array}{l}\text { Access to social security (retirement) } \\
\text { provided by government institutions }\end{array}$ & Social security, retirement \\
\hline STDs & $\begin{array}{l}\text { Prevalence of HIVIAIDS and other STDs in } \\
\text { coastal populations }\end{array}$ & HIVIAIDS, HIV, STDs \\
\hline Substance abuse & $\begin{array}{l}\text { Prevalence of addiction and dependence on } \\
\text { alcohol / illegal stimulants }\end{array}$ & $\begin{array}{l}\text { Drugs, addiction, substance } \\
\text { abuse }\end{array}$ \\
\hline Clean water & Access to water and sanitation & $\begin{array}{l}\text { Water AND sanitation, clean } \\
\text { water }\end{array}$ \\
\hline Land tenure & $\begin{array}{l}\text { Security of land tenure to home/property in } \\
\text { coastal population }\end{array}$ & $\begin{array}{l}\text { Land tenure, land ownership, } \\
\text { home ownership }\end{array}$ \\
\hline Disaster loss & $\begin{array}{l}\text { Damages, losses, and impacts from natural } \\
\text { or manmade disasters or conflicts. Specify } \\
\text { if it's loss to property (houses, fishing } \\
\text { gear, boats), lives, fishing infrastructure } \\
\text { (ports, processing facilities, aquaculture } \\
\text { equipment), or impacts on fishing practices/ } \\
\text { satisfaction. }\end{array}$ & $\begin{array}{l}\text { Disaster, tsunami, flood, sea } \\
\text { level rise }\end{array}$ \\
\hline Disaster recovery & $\begin{array}{l}\text { Disaster recovery from natural or manmade } \\
\text { disasters or conflicts. Examples include } \\
\text { types of government help (purchase } \\
\text { of equipment, rebuilding ports, direct } \\
\text { assistance to fishers), and fishers' recovery } \\
\text { efforts (forming new organizations, clean- } \\
\text { up efforts, rebuilding infrastructure, } \\
\text { purchasing equipment). }\end{array}$ & $\begin{array}{l}\text { Disaster, tsunami, flood, sea } \\
\text { level rise, disaster recovery }\end{array}$ \\
\hline Age & Average age of fishers & $\begin{array}{l}\text { Mean age, median age, } \\
\text { average age }\end{array}$ \\
\hline Offspring employment & $\begin{array}{l}\text { Economic activity of offspring (to measure } \\
\text { intragenerational greying of fishery) }\end{array}$ & $\begin{array}{l}\text { Children AND employment, } \\
\text { youth AND employment, } \\
\text { children AND economic } \\
\text { activity }\end{array}$ \\
\hline Urban proximity & $\begin{array}{l}\text { Proximity of fishing communities or landing } \\
\text { points to urban centres }\end{array}$ & $\begin{array}{l}\text { Urban centre AND proximity, } \\
\text { urban centre AND distance }\end{array}$ \\
\hline \multicolumn{3}{|l|}{ Environmental impacts } \\
\hline Catch emissions & $\begin{array}{l}\text { Catch per unit of measure (e.g. ton, boat, } \\
\text { effort) of carbon dioxide emissions }\end{array}$ & Catch AND $\mathrm{CO} 2$ \\
\hline Stock assessment & $\begin{array}{l}\text { Stock assessment available for targeted } \\
\text { stocks (yes/no) }\end{array}$ & Stock assessment \\
\hline $\begin{array}{l}\text { Conservation } \\
\text { participation }\end{array}$ & $\begin{array}{l}\text { Participation by fishers in environmental } \\
\text { issues or conservation measures (i.e., } \\
\text { creation of fisheries refuges, fishing } \\
\text { closures, no-fishing recovery zones, creation } \\
\text { of MPAs) }\end{array}$ & $\begin{array}{l}\text { Conservation AND } \\
\text { participation (both abstract), } \\
\text { conservation (abstract) AND } \\
\text { fisher participation (pdf) }\end{array}$ \\
\hline \multicolumn{3}{|l|}{ Institutional arrangements } \\
\hline Governance structure & $\begin{array}{l}\text { Self-governance structure (cooperative/ } \\
\text { associations or non-cooperative forms) }\end{array}$ & $\begin{array}{l}\text { Governance structure, fishing } \\
\text { organization, institutions }\end{array}$ \\
\hline Accountability & $\begin{array}{l}\text { Accountability of fishers and the state } \\
\text { (towards other fishers, the state) }\end{array}$ & Accountability \\
\hline $\begin{array}{l}\text { Non-governmental social } \\
\text { services }\end{array}$ & $\begin{array}{l}\text { Provision of social services }{ }^{35} \text { by their fishing } \\
\text { form of organization (yes/no) }\end{array}$ & $\begin{array}{l}\text { Retirement, health services, } \\
\text { health care }\end{array}$ \\
\hline Regulatory structure & $\begin{array}{l}\text { Formal regulatory structure (permitting/ } \\
\text { TURFs/ITQs/etc.) Survey }\end{array}$ & $\begin{array}{l}\text { Regulatory structure, } \\
\text { management strategies }\end{array}$ \\
\hline Governance participation & $\begin{array}{l}\text { Participation in decision-making processes } \\
\text { related to fisheries governance (regulatory, } \\
\text { operational, etc). }\end{array}$ & Governance AND participation \\
\hline \multicolumn{3}{|l|}{ Type of fishery involved } \\
\hline Gear change & $\begin{array}{l}\text { Changes of fishing gear used by fishers in a } \\
\text { community throughout the year }\end{array}$ & Seasonal change AND gear \\
\hline Gear ownership & $\begin{array}{l}\text { Ownership of fishing means of production } \\
\text { (\% or items: motor, boat, fishing gear) }{ }^{36}\end{array}$ & $\begin{array}{l}\text { Gear ownership, boat } \\
\text { ownership, equipment } \\
\text { ownership, own gear, own } \\
\text { boat }\end{array}$ \\
\hline
\end{tabular}

34 Cooperative forms of self-governance are defined as those that require collective action to succeed, and include any type of association such as a fishing co-op, a union, a federation, a confederation, etc. Non-cooperative forms of self-governance are those that do not require collective action to succeed, such as individual fishers contracting short term with a fish buyer, fish trader, patron, or intermediary (Basurto et al., 2013).

35 E.g. heath services, retirement security, etc.

36 This allows for understanding the level of dependence on patrons and "decent work". 
For reference, the minimum core data on fisheries and aquaculture that are recommended by FAO for inclusion in community and household surveys through a census framework (Gee, 2015) are as follows:

\begin{tabular}{|c|c|}
\hline Economic & $\begin{array}{l}\text { - Output (annual fishery production, annual aquaculture production, water areas } \\
\text { accessed by fishery, water areas under aquaculture facilities, annual fishery } \\
\text { yield by accessed water area, annual aquaculture yield by water area under } \\
\text { aquaculture facilities) } \\
\text { - Trade (export in quantity and value of fishery and aquaculture products, import } \\
\text { in quantity and value of fishery and aquaculture products) } \\
\text { - Stocks (fish resources kept in aquaculture facilities at the time of survey) } \\
\text { - Stock of resources (total water area, land area used for aquaculture, land cover } \\
\text { used for fishery, supporting activities, number of boats used) } \\
\text { - Inputs (water turnover rate for aquaculture, fertilizers used for aquaculture in } \\
\text { quantity and value, fertilizers used for environmental enhancement in quantity } \\
\text { and value, other chemicals used for aquaculture in quantity and value, seeds } \\
\text { for aquaculture in quantity and value, seeds released for stock enhancement in } \\
\text { quantity and value, feed used for aquaculture in quantity and value, feed used } \\
\text { for fishing operations in quantity and value) } \\
\text { - Agroprocessing (volume of fish used in processing food by aquaculture, value } \\
\text { of output of processed food by aquaculture, volume of fish used in processing } \\
\text { food by fishery, value of output of processed food by fishery, fish used for } \\
\text { no-food uses in quantity and value by purposes) } \\
\text { - Prices (producer prices of fishery product, producer process of aquaculture } \\
\text { product, consumer prices of fish products) } \\
\text { - Final expenditure (government expenditure on fishery development, } \\
\text { government expenditure on aquaculture development, levies for fisheries, } \\
\text { private investment, household consumption of fish in quantity and value) } \\
\text { - Rural infrastructure (hatcheries, ice plants) } \\
\text { - International transfer (Overseas Development Administration for fisheries and } \\
\text { aquaculture development) }\end{array}$ \\
\hline Social & $\begin{array}{l}\text { Demographics of urban and rural populations engaged in fisheries (sex, age, } \\
\text { country of birth, highest level of education completed, status in employment, } \\
\text { total income of the household) }\end{array}$ \\
\hline $\begin{array}{l}\text { Community- } \\
\text { level surveys } \\
\text { that include a } \\
\text { number of items } \\
\text { for the following } \\
\text { categories: }\end{array}$ & $\begin{array}{l}\text { - work } \\
\text { - community infrastructure and services } \\
\text { - species destination } \\
\text { - grants/subsidies } \\
\text { - governance }\end{array}$ \\
\hline $\begin{array}{l}\text { Household-level } \\
\text { surveys that } \\
\text { include a number } \\
\text { of questions for } \\
\text { the following } \\
\text { categories: }\end{array}$ & $\begin{array}{l}\text { - land and water use } \\
\text { - species destination } \\
\text { - equipment } \\
\text { - inputs } \\
\text { - unexpected losses } \\
\text { - work (for individuals) } \\
\text { - food consumption and quality of life (for individuals) }\end{array}$ \\
\hline
\end{tabular}

Source: Gee, 2015. 


\section{Appendix 4. Synthesis of measures recorded in scientific literature since 2011}

SSF indicators listed in Appendix 3 were searched in the scientific literature, for the period of 2012-2016, in order to assess how different researchers empirically measured these indicators and at what spatial scale. Those articles that empirically measured at least one of the indicators were included in the inventory, and the methods used recorded, as well as the spatial scale at which the measurement was taken (according to political description of scale: substate, state, national or global). The table below provides a summary of the articles found:

\begin{tabular}{|c|c|c|c|c|c|c|}
\hline Indicator & $\begin{array}{l}\text { Theory } \\
\text { developed? } \\
\text { (yes/no) }\end{array}$ & $\begin{array}{l}\text { Methodology } \\
\text { described? } \\
\text { (yes/no) }\end{array}$ & $\begin{array}{l}\text { Proof of } \\
\text { concept? } \\
\text { (yes/no) }\end{array}$ & $\begin{array}{l}\text { Several } \\
\text { measures } \\
\text { available? } \\
\text { (yes/no) }\end{array}$ & Location & Scale \\
\hline Accountability & $Y$ & $Y$ & $\mathrm{~N}$ & $N$ & Asia & SS \\
\hline Age & $\mathrm{Y}$ & $Y$ & $\mathrm{Y}$ & $Y$ & Many & SS, S, N \\
\hline $\begin{array}{l}\text { Catch } \\
\text { emissions }\end{array}$ & $\mathrm{Y}$ & $Y$ & $Y$ & $\mathrm{~N}$ & S. America & $\mathrm{N}$ \\
\hline $\begin{array}{l}\text { Access to clean } \\
\text { water }\end{array}$ & $\mathrm{Y}$ & $Y$ & $\mathrm{Y}$ & $\mathrm{N}$ & Asia & SS, S, N \\
\hline $\begin{array}{l}\text { Consumption } \\
\text { market }\end{array}$ & $\mathrm{Y}$ & $\mathrm{Y}$ & $\mathrm{Y}$ & $\mathrm{Y}$ & $\begin{array}{l}\text { S. America, } \\
\text { Asia, } \\
\text { E. Africa, } \\
\text { Micronesia }\end{array}$ & SS, S, N \\
\hline CPUE & $\mathrm{Y}$ & $Y$ & $\mathrm{Y}$ & $Y$ & $\begin{array}{l}\text { S. America } \\
\text { Europe } \\
\text { Asia }\end{array}$ & SS,S \\
\hline Dependents & $\mathrm{Y}$ & $Y$ & $\mathrm{Y}$ & $\mathrm{Y}$ & Asia & $\mathrm{S}, \mathrm{N}$ \\
\hline Disadvantaged & $\mathrm{Y}$ & $Y$ & $\mathrm{Y}$ & $Y$ & $\begin{array}{l}\text { South } \\
\text { Africa, S. } \\
\text { America, } \\
\text { Europe, } \\
\text { Asia }\end{array}$ & SS, S, N \\
\hline Disaster loss & $Y$ & $Y$ & $\mathrm{Y}$ & $\mathrm{Y}$ & $\begin{array}{l}\text { Asia, S. } \\
\text { America }\end{array}$ & SS \\
\hline $\begin{array}{l}\text { Disaster } \\
\text { recovery }\end{array}$ & $\mathrm{Y}$ & $Y$ & $\mathrm{Y}$ & $\mathrm{Y}$ & $\begin{array}{l}\text { Asia, } \mathrm{S} . \\
\text { America }\end{array}$ & SS, S \\
\hline Discards & $\mathrm{Y}$ & $Y$ & $\mathrm{Y}$ & $\mathrm{Y}$ & $\begin{array}{l}\text { Europe, } \\
\text { Asia, N. } \\
\text { America }\end{array}$ & $\mathrm{S}, \mathrm{N}$ \\
\hline Exports & $\mathrm{Y}$ & $Y$ & $\mathrm{Y}$ & $\mathrm{Y}$ & $\begin{array}{l}\text { N. America } \\
\text { S. America } \\
\text { Europe } \\
\text { Asia }\end{array}$ & SS, S, N \\
\hline Food waste & $\mathrm{N}$ & $\mathrm{N}$ & $\mathrm{N}$ & $\mathrm{N}$ & $\mathrm{N}$ & $\mathrm{N}$ \\
\hline
\end{tabular}




\begin{tabular}{|c|c|c|c|c|c|c|}
\hline Indicator & $\begin{array}{l}\text { Theory } \\
\text { developed? } \\
\text { (yes/no) }\end{array}$ & $\begin{array}{l}\text { Methodology } \\
\text { described? } \\
\text { (yes/no) }\end{array}$ & $\begin{array}{l}\text { Proof of } \\
\text { concept? } \\
\text { (yes/no) }\end{array}$ & $\begin{array}{l}\text { Several } \\
\text { measures } \\
\text { available? } \\
\text { (yes/no) }\end{array}$ & Location & Scale \\
\hline Gear change & $\mathrm{Y}$ & $\mathrm{Y}$ & $\mathrm{Y}$ & $\mathrm{Y}$ & $\begin{array}{l}\text { N. America } \\
\text { E. Africa } \\
\text { S. America } \\
\text { Asia }\end{array}$ & SS, N \\
\hline $\begin{array}{l}\text { Gear } \\
\text { ownership }\end{array}$ & $\mathrm{Y}$ & $\mathrm{Y}$ & $\mathrm{Y}$ & $\mathrm{Y}$ & $\begin{array}{l}\text { Europe } \\
\text { N. America } \\
\text { S. America } \\
\text { C. America }\end{array}$ & SS, N \\
\hline $\begin{array}{l}\text { Governance } \\
\text { participation }\end{array}$ & $\mathrm{Y}$ & $\mathrm{Y}$ & $\mathrm{Y}$ & $\mathrm{Y}$ & $\begin{array}{l}\text { N. America } \\
\text { Asia } \\
\text { C. America } \\
\text { S. America } \\
\text { E. Africa }\end{array}$ & SS \\
\hline $\begin{array}{l}\text { Governance } \\
\text { structure }\end{array}$ & $\mathrm{Y}$ & Y & $\mathrm{Y}$ & $\mathrm{Y}$ & $\begin{array}{l}\text { N. America } \\
\text { Asia } \\
\text { E. Africa }\end{array}$ & SS \\
\hline $\begin{array}{l}\text { Access to } \\
\text { health services }\end{array}$ & $\mathrm{Y}$ & $\mathrm{Y}$ & $\mathrm{Y}$ & $\mathrm{Y}$ & $\begin{array}{l}\text { S. America } \\
\text { Asia } \\
\text { N. America }\end{array}$ & SS \\
\hline $\begin{array}{l}\text { Household } \\
\text { economy }\end{array}$ & $\mathrm{Y}$ & $\mathrm{Y}$ & $\mathrm{Y}$ & $\mathrm{N}$ & $\begin{array}{l}\text { Sierra } \\
\text { Leone }\end{array}$ & $\mathrm{N}$ \\
\hline $\begin{array}{l}\text { Indigenous } \\
\text { workforce }\end{array}$ & Y & $\mathrm{Y}$ & $\mathrm{Y}$ & $\mathrm{Y}$ & $\begin{array}{l}\text { Oceania } \\
\text { Asia } \\
\text { Mexico }\end{array}$ & SS, N \\
\hline Land tenure & $\mathrm{Y}$ & $\mathrm{Y}$ & $\mathrm{Y}$ & $\mathrm{Y}$ & $\begin{array}{l}\text { Asia } \\
\text { S. America }\end{array}$ & SS, N \\
\hline Literacy & $\mathrm{Y}$ & $\mathrm{Y}$ & $\mathrm{Y}$ & $\mathrm{Y}$ & $\begin{array}{l}\text { Asia } \\
\text { S. America } \\
\text { Africa }\end{array}$ & SS, GLOB \\
\hline Micronutrients & $\mathrm{N}$ & $\mathrm{N}$ & $\mathrm{N}$ & $\mathrm{N}$ & $\mathrm{N}$ & $\mathrm{N}$ \\
\hline $\begin{array}{l}\text { Non- } \\
\text { governmental } \\
\text { social services }\end{array}$ & $\mathrm{N}$ & $\mathrm{N}$ & $\mathrm{N}$ & $\mathrm{N}$ & $\mathrm{N}$ & $\mathrm{N}$ \\
\hline $\begin{array}{l}\text { Nutrition } \\
\text { substitute }\end{array}$ & $\mathrm{Y}$ & $N$ & $N$ & $N$ & NA & $\mathrm{N}$ \\
\hline $\begin{array}{l}\text { Offspring } \\
\text { employment }\end{array}$ & $\mathrm{Y}$ & $\mathrm{Y}$ & $\mathrm{Y}$ & $\mathrm{N}$ & $\begin{array}{l}\text { S. America } \\
\text { N. America } \\
\text { Asia }\end{array}$ & SS, S \\
\hline Protein & $\mathrm{Y}$ & $\mathrm{Y}$ & $\mathrm{Y}$ & $\mathrm{N}$ & $\begin{array}{l}\text { Oceania } \\
\text { S. Africa }\end{array}$ & $\begin{array}{l}\text { SS, S, N, } \\
\text { GLOB }\end{array}$ \\
\hline $\begin{array}{l}\text { Regulatory } \\
\text { structure }\end{array}$ & $\mathrm{Y}$ & Y & $\mathrm{Y}$ & $N$ & Europe & N, GLOB \\
\hline Social security & $\mathrm{Y}$ & $\mathrm{Y}$ & $\mathrm{Y}$ & Y & $\begin{array}{l}\text { Europe } \\
\text { N. America }\end{array}$ & SS \\
\hline STDs & $\mathrm{Y}$ & $\mathrm{Y}$ & $\mathrm{N}$ & $\mathrm{N}$ & N. America & SS, GLOB \\
\hline $\begin{array}{l}\text { Stock } \\
\text { assessment }\end{array}$ & $\mathrm{Y}$ & $\mathrm{Y}$ & $\mathrm{Y}$ & $\mathrm{Y}$ & Global & SS, S, N \\
\hline Subsidy & $\mathrm{Y}$ & $\mathrm{Y}$ & $\mathrm{Y}$ & $\mathrm{N}$ & $\begin{array}{l}\text { Africa } \\
\text { Europe }\end{array}$ & SS, N \\
\hline $\begin{array}{l}\text { Substance } \\
\text { abuse }\end{array}$ & $\mathrm{Y}$ & $\mathrm{Y}$ & $\mathrm{Y}$ & $\mathrm{N}$ & $\begin{array}{l}\text { N. America } \\
\text { S. America }\end{array}$ & SS, S \\
\hline
\end{tabular}




\begin{tabular}{|l|l|l|l|l|l|l|}
\hline Indicator & $\begin{array}{l}\text { Theory } \\
\text { developed? } \\
\text { (yes/no) }\end{array}$ & $\begin{array}{l}\text { Methodology } \\
\text { described? } \\
\text { (yes/no) }\end{array}$ & $\begin{array}{l}\text { Proof of } \\
\text { concept? } \\
\text { (yes/no) }\end{array}$ & $\begin{array}{l}\text { Several } \\
\text { measures } \\
\text { available? } \\
\text { (yes/no) }\end{array}$ & Location & Scale \\
\hline Traceability & $Y$ & $Y$ & $Y$ & N & $\begin{array}{l}\text { Asia } \\
\text { C. America } \\
\text { S. America } \\
\text { N. America } \\
\text { Europe }\end{array}$ & SS, N, GLOB \\
\hline $\begin{array}{l}\text { E. Africa } \\
\text { proximity }\end{array}$ & $Y$ & $Y$ & $Y$ & $Y$ & $\begin{array}{l}\text { S. America } \\
\text { Asia }\end{array}$ & SS, S \\
\hline Use & $Y$ & $Y$ & $Y$ & $Y$ & E. Africa & S, N \\
\hline
\end{tabular}

$S S=$ Sub-State, $S=$ State, $N=$ National, $G L O B=$ Global

Similarly, the number of articles measuring each indicator is summarized below, according to the spatial scale of measurement:

\section{Number of Articles Recording Data for Each Indicator, by Spatial Scale}

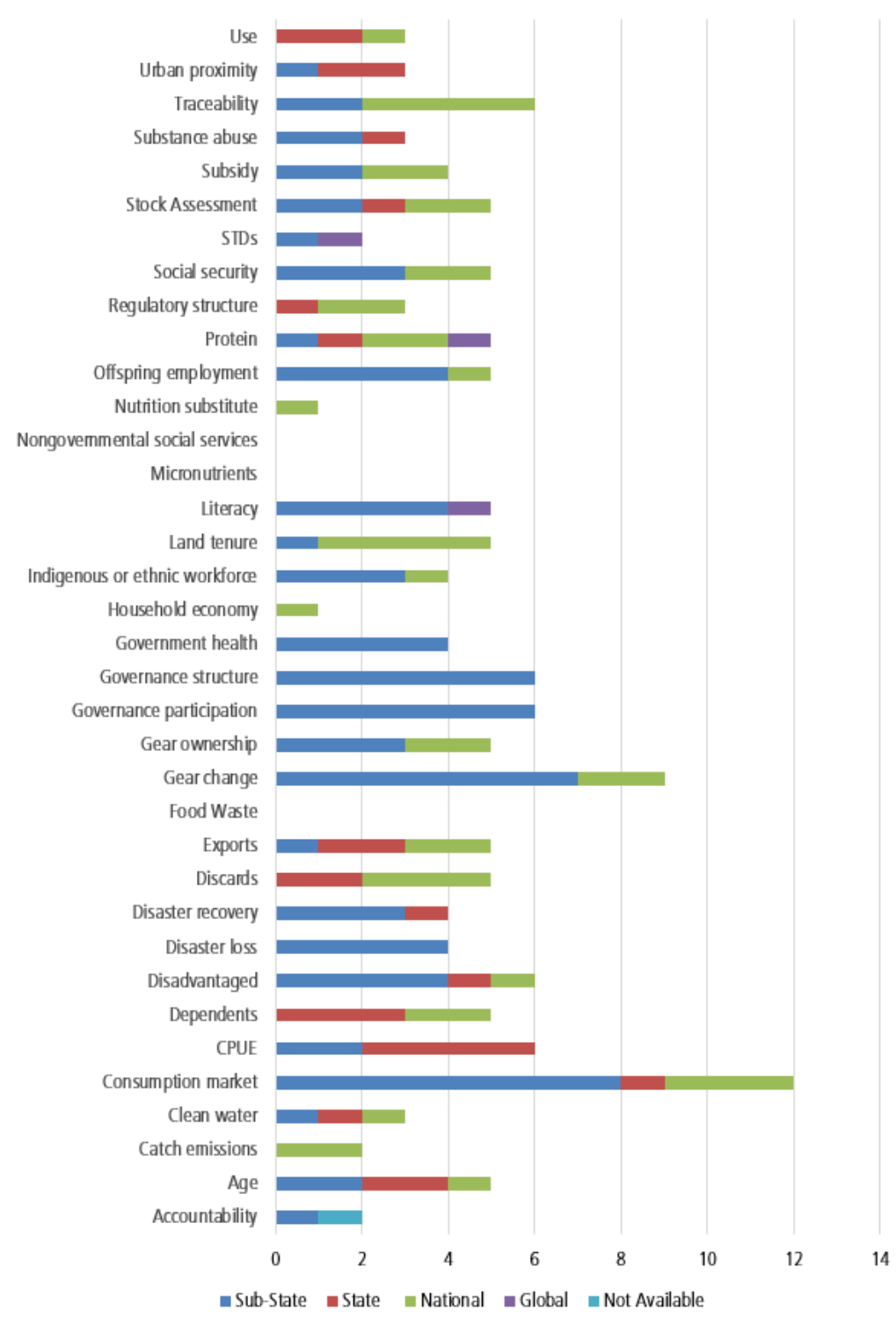


In 2012, the World Bank, FAO and WorldFish Center published Hidden Harvest: The Global Contribution of Capture Fisheries. This was a review of the economic importance of fisheries, and while providing essential information and estimates that are still valid, the analyses would benefit from being refined and updated, and also by including additional dimensions of the contribution of small-scale fisheries to food security and nutrition, poverty reduction, and the three pillars of sustainable development more broadly.

The intention of an updated study would be to draw the attention of policy- and decision-makers to the sector's importance and to promote the required engagement and support to realize the potential of sustainable small-scale fisheries. Such an analysis would also be an important contribution towards monitoring of the implementation of the Voluntary Guidelines for Securing Sustainable Small-Scale Fisheries in the Context of Food Security and Poverty Eradication (SSF Guidelines) and of the progress towards the achievement of the Sustainable Development Goals (SDGs).

As a first step towards a new Hidden Harvest study, the "Workshop on improving our knowledge on small-scale fisheries: data needs and methodologies" was held at FAO in Rome, Italy on 27-29 June 2017. This expert workshop discussed:

- the scope and main contents of the new study, including type of data (indicators) to be collected and subsector coverage; and

- the methodologies for data collection and analyses, including key partners and information sources.

About 40 external experts as well as FAO staff agreed on the need for a comprehensive new study to illuminate the hidden contributions of small-scale fisheries to the three dimensions of sustainable development, and to identify the key threats to these contributions. The study should be a collaborative effort and the next steps envisaged include the development of a study design based on the workshop outcomes, the continuation of ongoing communications and partnership development, and launch of the research in early 2018, with a target for completion in the first half of 2019. 




\title{
Improving our knowledge on small-scale fisheries: data needs and methodologies
}

\author{
Workshop proceedings
}

27-29 June 2017

FAO, Rome, Italy

In 2012, the World Bank, FAO and WorldFish Center published a review of the economic importance of fisheries entitled Hidden Harvest: The Global Contribution of Capture Fisheries. While providing essential information and estimates that are still valid, the analyses would benefit from being refined and updated, and also by including additional dimensions of the contribution of small-scale fisheries to food security and nutrition, poverty reduction, and the three dimensions of sustainable development more broadly. The intention would be to draw the attention of policy- and decision-makers to the sector's importance and to promote the required engagement and support to realize the potential of sustainable smallscale fisheries. Such an analysis would also be an important contribution towards monitoring the implementation of the Voluntary Guidelines for Securing Sustainable SmallScale Fisheries in the Context of Food Security and Poverty Eradication (SSF Guidelines), and of the progress towards the achievement of the Sustainable Development Goals (SDGs). As a first step towards a new Hidden Harvest study, the "Workshop on improving our knowledge on small-scale fisheries: data needs and methodologies" was held at FAO in Rome, Italy on 27-29 June 2017. The workshop agreed on the need for a comprehensive new study to illuminate the hidden contributions of small-scale fisheries to the three dimensions of sustainable development, as well as identifying the key threats to these contributions.

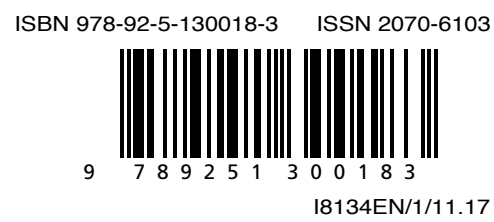

